CÍNTIA SCUCUGLIA HELUANY

SISTEMA NERVOSO SIMPÁTICO NA ATIVAÇÃO DA GLÂNDULA SUBMANDIBULAR E PARÓTIDA DE CAMUNDONGOS

Dissertação apresentada ao Programa de Pós-Graduação em Biologia Celular e Tecidual do Instituto de Ciências Biomédicas da Universidade de São Paulo, para a obtenção do Título de Mestre em Ciências. 
CÍNTIA SCUCUGLIA HELUANY

\section{SISTEMA NERVOSO SIMPÁTICO NA ATIVAÇÃO DA GLÂNDULA SUBMANDIBULAR E PARÓTIDA DE CAMUNDONGOS}

Dissertação apresentada ao
Programa de Pós-Graduação em
Biologia Celular e Tecidual do Instituto
de Ciências Biomédicas da
Universidade de São Paulo, para a
obtenção do Título de Mestre em
Ciências.

Área de concentração:

Biologia Celular e Tecidual

Orientadora:

Dra. Norma Yamanouye

Versão original 
DADOS DE CATALOGAÇÃO NA PUBLICAÇÃO (CIP)

Serviço de Biblioteca e Informação Biomédica do

Instituto de Ciências Biomédicas da Universidade de São Paulo

๑๑ reprodução total

Heluany, Cíntia Scucuglia.

Sistema nervoso simpático na ativação da glândula submandibular e parótida de camundongos / Cíntia Scucuglia Heluany. -- São Paulo, 2013.

Orientadora: Profa. Dra. Norma Yamanouye.

Dissertação (Mestrado) - Universidade de São Paulo. Instituto de Ciências Biomédicas. Departamento de Biologia Celular e do

Desenvolvimento. Área de concentração: Biologia Celular e Tecidual. Linha de pesquisa: Papel da inervação noradrenérgica em glândulas salivares de mamíferos.

Versão do título para o inglês: Sympathetic outflow on activation of the mouse submandibular and parotid glands.

1. Sistema nervoso simpático 2. Adrenoceptores 3. Glândula Submandibular 4. Glândula Parótida 5. Proteínas I. Yamanouye, Profa. Dra. Norma II. Universidade de São Paulo. Instituto de Ciências

Biomédicas. Programa de Pós-Graduação em Biologia Celular e Tecidual III. Título. 


\begin{abstract}
Candidato(a): $\quad$ Cíntia Scucuglia Heluany.
Título da Dissertação: $\quad$ Sistema nervoso simpático na ativação da glândula submandibular e parótida de camundongos.
\end{abstract}

Orientador(a): $\quad$ Profa. Dra. Norma Yamanouye.

A Comissão Julgadora dos trabalhos de Defesa da Dissertação de Mestrado, em sessão pública realizada a considerou
( ) Aprovado(a)
( ) Reprovado(a)

Examinador(a): Assinatura:

Nome:

Instituição:

Examinador(a): Assinatura:

Nome:

Instituição:

Presidente: Assinatura:

Nome:

Instituição: 


\section{Certificado}

Certificamos que o protocolo registrado sob $n^{\circ} 062$ nas fls. 103 do livro 02 para uso de animais em experimentação, sob a responsabilidade do Prof(a) $\operatorname{Dr}(a))$ Norma Yamanouye, Coordenador(a) da Linha de pesquisa "Sistema nervoso simpático na ativação da glândula submandibular e parótica de camundongos" do qual participam o(s) alunos Cíntia Scucuglia Heluany, Milene Schmidt Luna, está de acordo com os Princípios Éticos de Experimentação Animal adotado pela Sociedade Brasileira de Ciência de Animais de Laboratório (SBCAL) e foi aprovado pela COMISSÃO DE ÉTICA NO USO DE ANIMAIS (CEUA) em 15.07.2011, com validade de 3 anos.

São Paulo, 18 de julho de 2011.
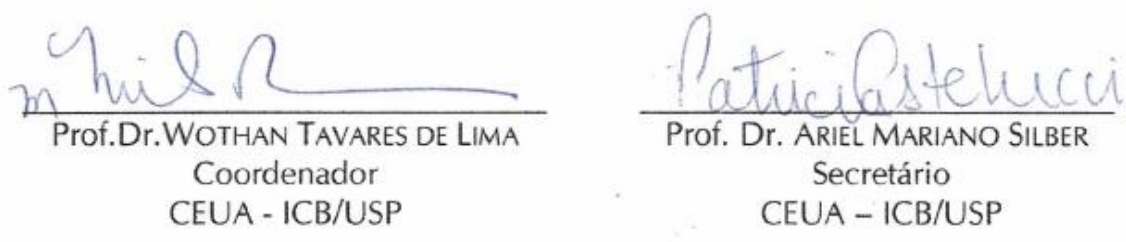


\section{CERTIFICADO}

Certificamos que o Projeto intitulado "Sistema nervoso simpático na ativação da glândula submandibular e parótida de camundongos" protocolo $n^{\circ} 640 / 09$, sob a responsabilidade de Dra. Norma Yamanouye, Milene Schmidt do Amaral e Luna e Cíntia Scucuglia Heluany, está de acordo com os Princípios Éticos na Experimentação Animal adotado pelo Colégio Brasileiro de Experimentação Animal (COBEA), e foi aprovado pela COMISSÃO DE ÉTICA NO USO DE ANIMAIS DO INSTITUTO BUTANTAN (CEUAIB) em reunião de 11/08/2009.

We certify that the research entitled "Sympathetic nercous system on activation of mouse submandibular and parotid glands", protocol $n^{\circ} 640 / 09$, under the responsibility of Dra. Norma Yamanouye, Milene Schmidt do Amaral e Luna e Cíntia Scucuglia Heluany, is in agreement with the Ethical Principles in Animal Research, adopted by the Brazilian College of Animal Experimentation, and was approved by the ETHICAL COMMITTEE FOR ANIMAL RESEARCH of BUTANTAN INSTITUTE in the meeting of $\underline{08 / 11 / 2009}$

\begin{tabular}{|c|c|}
\hline $\begin{array}{l}\text { Vigência do Projeto: } \\
08 / 2009-07 / 2012\end{array}$ & $\mathrm{~N}^{\circ}$ de animais/espécie \\
\hline $\begin{array}{l}\text { Divisão de desenvolvimento } \\
\text { científico - Lab. farmacologia }\end{array}$ & 150/Camundongo swiss/c/ macho \\
\hline
\end{tabular}

São Paulo, 13 de agosto de 2009.

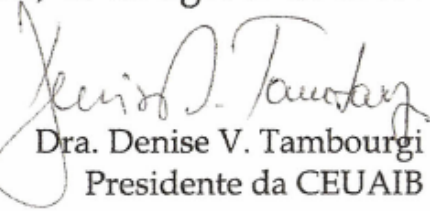

De acordo:

Dr. Otávio Azevedo Mercadante

Diretor do Instituto Butantan 
À minha mãe Rosane, por ser a principal responsável pela minha formação pessoal e profissional, que com suas palavras de conforto SEMPRE me estimulou a seguir em frente, por ser um exemplo de extrema dedicação e amor à sua profissão, $\mathrm{o}$ que me fez querer ser igual. E por todas as vezes que abriu mão de tudo por mim e por meus irmãos. Muito obrigada!

Ao meu pai Luís, por todos os ensinamentos que me passou, pelas experiências trocadas, por acreditar sempre em mim e em meu potencial, e por não medir esforços para me ajudar. Muito Obrigada! 
Aos meus irmãos, Marina e Dodô, por toda amizade e carinho e pelo incentivo e apoio incondicional que me dão força para não desistir e seguir em frente nesta difícil jornada. E ainda, à Marina, por nossas sessões de conversas e desabafos que me fizeram enxergar muitas coisas com outros olhos.

Muito Obrigada! 


\section{AGRADECIMENTOS}

Gostaria de agradecer várias pessoas, as quais direta ou indiretamente foram fundamentais para a realização deste trabalho. A todos vocês só posso dizer: "muitíssimo obrigada!"

Primeiramente, à Dra. Norma Yamanouye, não só pela orientação, mas pelo incentivo e por todos os ensinamentos que me passou, os quais contribuíram para que eu pudesse aprender a fazer ciência de uma maneira muito mais prazerosa e correta, me fazendo ter ainda mais certeza da escolha que fiz para minha vida profissional.

À Agência de Fomento FAPESP pelo Auxílio Financeiro e pela Bolsa de Mestrado concedida durante a realização deste trabalho (2010/13172-6).

Aos pesquisadores Dr. Jonas Perales e Dr. Richard Hemmi Valente, do Laboratório de Toxinologia do Instituto Oswaldo Cruz- FIOCRUZ, pela disponibilidade em me receber em seu laboratório para realização dos experimentos de espectrometria de massas e principalmente por todo suporte nas análises dos dados e em sanar as enormes dúvidas.

À Celiana, secretária do Programa de Pós-graduação em Biologia Celular e Tecidual do Departamento de Biologia Celular e do Desenvolvimento do Instituto de Ciências Biomédicas - USP, que sempre esclareceu todas as dúvidas.

À Dr. Anita Mitico Tanaka, do Laboratório de Herpetologia do Instituto Butantan por disponibilizar seus equipamentos para realização de alguns experimentos de Eletroforese Bidimensional.

Ao Dr. Marcelo Santoro, do Laboratório de Fisiopatologia do Instituto Butantan, por disponibilizar seu equipamento para realização de alguns experimentos de Eletroforese Bidimensional.

Aos pesquisadores, funcionários e colegas do Laboratório de Farmacologia do Instituto Butantan por toda ajuda e disponibilidade que contribuíram para a realização deste trabalho, e também por todo esse período de ótima convivência. 
À amiga Milene, por toda a amizade, convivência e imensurável ajuda em várias etapas deste trabalho, me acalmando tantas vezes quando eu me sentia completamente perdida e desesperada.

Às amigas do laboratório: Andréia, Beatriz e Luciana, por toda amizade e disponibilidade em me ouvir e ajudar tanto com dúvidas e problemas profissionais como pessoais.

Aos amigos do Laboratório de Farmacologia pela amizade, pelos ótimos momentos de diversão, pelos nossos almoços animados e pelo total apoio nas horas necessárias, principalmente aos amigos Thiago, Adriana Martins, Adriana Mezini, Luciane, Andria, Rafaela e Gustavo. E também às amigas agregadas da Farmacologia, Mari e Carol, que não foram menos importantes em toda esta etapa.

À minha irmã Marina e à amiga Jacqueline, por todos esses anos que dividimos não só um apartamento, mas também as alegrias, angústias, problemas e também as conquistas.

Às amigas desde o tempo da faculdade, Maraysa e Amanda, que mesmo não tendo um contato tão frequente, sempre estavam disponíveis a me ajudarem, me ouvirem quando necessário e também por mostrarem novas visões sobre nossas escolhas profissionais.

Às queridas vó Célia, Nair e às minhas amigas de Guaranésia, por todo apoio e incentivo que sempre me deram em todas as escolhas que decidi fazer na minha vida.

À tia Rúbia, pelas enriquecedoras conversas sobre ciência e sobre a vida. 
"Não basta saber, deve-se também aplicar... Não é suficiente querer, deve-se também fazer..." 


\section{RESUMO}

HELUANY, C. S. Sistema nervoso simpático na ativação da glândula submandibular e parótida de camundongos. 2013. 94 f. Dissertação (Mestrado em Biologia Celular e Tecidual). Instituto de Ciências Biomédicas, Universidade de São Paulo, São Paulo, 2013.

Dados da literatura mostram que a inervação simpática possui papel apenas na síntese e secreção das proteínas da saliva. Entretanto, nós mostramos anteriormente que a inervação noradrenérgica, estimulada logo após a extração de veneno, regula a síntese de proteínas que são importantes para ativar a glândula de veneno da serpente Bothrops jararaca, uma glândula exócrina relacionada às glândulas salivares. O objetivo desta dissertação foi verificar o papel da inervação simpática na manutenção da ativação das glândulas submandibulares e parótidas de camundongo e identificar as proteínas cujas sínteses são reguladas pela inervação simpática. Neste trabalho, utilizando reserpina como uma ferramenta farmacológica para verificar o papel da inervação simpática na funcionalidade das glândulas salivares de mamíferos, mostramos que na glândula submandibular de camundongo, a estimulação da inervação simpática regula positivamente a síntese de espécies de proteínas relacionadas à organização do citoesqueleto, biossíntese de proteínas, proteólise, sinalização intracelular, processos biossintéticos e metabólicos e negativamente a síntese de outras espécies de proteínas relacionadas à organização do citoesqueleto, biossíntese de proteínas, processos biossintéticos e metabólicos. Na glândula parótida, a estimulação da inervação simpática regula positivamente a síntese de espécies de proteínas relacionadas à organização do citoesqueleto, transcrição gênica, sinalização intracelular e cadeia respiratória e regula negativamente a síntese de espécies de proteínas relacionadas aos processos biossintéticos, metabólicos e catabólicos. Vale ressaltar ainda que, na glândula parótida o tratamento crônico com reserpina levou a um aumento do número de várias espécies de proteínas secretadas e a posterior administração de agonistas de adrenoceptores alfa e beta reverteu esse efeito, sugerindo que a estimulação da inervação simpática é importante para o processo de exocitose nesta glândula. Em conclusão, os resultados sugerem que a inervação simpática possui um papel relevante para homeostase celular das glândulas salivares de camundongos, mantendo a funcionalidade destas glândulas, isto é, mantendo as glândulas em constante estado de ativação, através da regulação da síntese de diferentes proteínas destas glândulas ou promovendo a exocitose de proteínas da saliva. Além disso, os resultados mostram que a inervação simpática atua de maneira diferente nas glândulas submandibulares e parótidas de camundongos. O conhecimento das proteínas que têm as suas expressões reguladas pela atividade simpática irá trazer novas informações sobre a função desta inervação nas glândulas salivares, podendo contribuir também para uma melhor compreensão sobres doenças da cavidade oral, bem como levar a uma melhora dos procedimentos terapêuticos.

Palavras-chave: Análise proteômica. Inervação noradrenérgica. Adrenoceptores. Glândula submandibular. Glândula Parótida. Camundongos. 


\begin{abstract}
HELUANY, C. S. Sympathetic outflow on activation of the mouse submandibular and parotid glands. 2013. 94 p. Mastersthesis (Cell and Tissue Biology) - Instituto de Ciências Biomédicas, Universidade de São Paulo, São Paulo, 2013.

Data in literature show that sympathetic outflow has a role only in stimulating synthesis and secretion of the saliva proteins in mammals. However, we previously showed that that stimulation of noradrenergic innervation after venom extraction regulates the synthesis of proteins that are important to activate the venom gland of Bothrops jararaca, an exocrine gland related to salivary glands. The aim of this study was to investigate the role of sympathetic outflow in maintaining the activation of the mouse submandibular and parotid glands and identify the proteins whose synthesis are regulated by noradrenergic innervation. In this work, using reserpine as a pharmacological tool to verify the role of the sympathetic outflow on the mammals salivary glands function, we observed that in the mouse submandibular gland, stimulation of the sympathetic outflow upregulates the synthesis of species of proteins related to cytoskeleton organization, protein biosynthesis, proteolysis, intracellular signaling, metabolic and biosynthetic processes, and downregulates the synthesis of other species of proteins related to cytoskeleton organization, protein biosynthesis, metabolic and biosynthetic processes. In the parotid gland, stimulation of the sympathetic outflow upregulates the synthesis of species of proteins related to cytoskeleton organization, gene transcription, intracellular signaling and respiratory chain and downregulates the synthesis of species of proteins involved in biosynthetic, metabolic and catabolic processes. It is worth mentioning that in the parotid gland, chronic treatment with reserpine led to an increase in the number of different species of secreted proteins and further administration with alpha- and beta-adrenoceptor agonists reversed this effect, suggesting that the sympathetic outflow is important to the process of exocytosis in this gland. In conclusion, these results suggest that the sympathetic outflow has an important role for cellular homeostasis in the mouse salivary glands, keeping the function of these glands by maintaining the glands in a constant activated stage by regulating the synthesis of different proteins or promoting the exocytosis of secreted proteins. Furthermore, these results show that sympathetic outflow acts differently in the mouse submandibular and parotid glands. The knowledge of the proteins that have their synthesis regulated by sympathetic outflow will bring new insights on the role of sympathetic outflow in the salivary glands, and may contribute to better understand oral diseases improving the therapy procedures.
\end{abstract}

Key-words: Proteomic analysis. Noradrenergic innervation. Adrenoceptors. Submandibular gland. Parotid gland. Mouse. 


\section{LISTA DE ILUSTRAÇÕES}

Figura 1: Representação diagramática dos compartimentos das glândulas salivares maiores.

Figura 2: Secreção salivar reflexa.

Figura 3: Desenho esquemático da distribuição de nervos para os diferentes efetores de uma glândula salivar.. .26

Figura 4: Glândula de veneno de serpentes Viperidade

Figura 5: Efeitos da reserpina e da estimulação dos adrenoceptores alfa e beta na composição proteica das glândulas submandibulares em camundongos previamente reserpinizados.

Figura 6: Diagrama de Venn representando o número de spots exclusivos presentes nos extratos de glândulas submandibulares e em comum entre os grupos experimentais.

Figura 7: Gel 2-DE de SDS-poliacrilamida de extrato de glândula submandibular de camundongo indicando os spots exclusivos selecionados nos 3 grupos experimentais que foram submetidos à espectrometria de massas.

Figura 8: Distribuição subcelular das espécies de proteínas exclusivas presentes nos extratos de glândulas submandibulares de camundongos de cada grupo experimental identificadas por espectrometria de massas. .54

Figura 9: Distribuição das espécies de proteínasexclusivas presentes nos extratos de glândulas submandibulares de camundongos de cada grupo experimental identificadas por espectrometria de massas de acordo com suas funções celulares.

Figura 10: Gel 2-DE de SDS-poliacrilamida de extrato de glândula submandibular de camundongo indicando os spots comuns aos 3 grupos experimentais que foram submetidos à espectrometria de massas

Figura 11: Distribuição subcelular das espécies de proteínas identificadas presentes em extratos de glândulas submandibulares de camundongos dos 3 grupos experimentais

Figura 12: Distribuição das espécies de proteínas identificadas presentes nos extratos de glândulas submandibulares de camundongos dos 3 grupos experimentais de acordo com suas categorias funcionais. 
Figura 13: Gel 2-DE de SDS-poliacrilamida de extrato de glândula submandibular de camundongo indicando os spots comuns entre o grupo controle e o grupo dos animais tratados com reserpina, fenilefrina e isoprenalina que foram submetidos à espectrometria de massas.

Figura 14: Distribuição subcelular das espécies de proteínas identificadas presentes nos extratos de glândulas submandibulares de camundongos do grupo controle e do grupo dos animais tratados com RES + FEN + ISO

Figura 15: Distribuição das espécies de proteínas identificadas presentes extratos glândulas submandibulares de camundongos do grupo controle e do grupo dos animais tratados com RES + FEN + ISO de acordo com suas categorias funcionais 64

Figura 16: Efeitos da reserpina e da estimulação dos adrenoceptores alfa e beta em animais previamente reserpinizados na composição proteica das glândulas parótidas de camundongos.

Figura 17: Diagrama de Venn representando o número de spots exclusivos presentes nos extratos de glândulas parótidas e em comum entre os 3 grupos experimentais.....66

Figura 18: Gel 2-DE de SDS-poliacrilamida de extrato de glândula parótida de camundongo indicando os spots exclusivos selecionados nos 3 grupos experimentais que foram submetidos à espectrometria de massas. .68

Figura 19: Distribuição subcelular das espécies de proteínas exclusivas presentes nos extratos de glândulas parótidas de camundongos de cada grupo experimental identificadas por espectrometria de massas .70

Figura 20: Espécies de proteínas secretadas reguladas pela inervação simpática 71

Figura 21: Distribuição das espécies de proteínas exclusivas presentes nos extratos de glândulas parótidas de camundongos de cada grupo experimental identificadas por espectrometria de massas de acordo com suas funções celulares. .72 


\section{LISTA DE TABELAS}

Tabela1: Protocolo de focalização isoelétrica utilizado para fitas de $13 \mathrm{~cm}, \mathrm{pH} 3$ 10. 43

Tabela 2: Densidades dos spots comuns aos 3 grupos experimentais que tiveram as densidades diminuídas após tratamento crônico com reserpina em relação ao grupo controle e restauradas após o tratamento com os agonistas de adrenoceptores.

Tabela 3: Densidades dos spots comuns aos 3 grupos experimentais que tiveram as densidades aumentadas após tratamento crônico com reserpina em relação ao grupo controle e restauradas após o tratamento com os agonistas de adrenoceptores. .58 


\section{SUMÁRIO}

1 INTRODUÇÃO__ 19

1.1 Glândulas Salivares__ 20

1.2 Controle Nervoso das Glândulas salivares __ 25

1.3 Glândula de Veneno da serpente Bothrops jararaca __ 30

1.4 Importância da saliva __ 32

1.5 Relevância __ 34

2 OBJETIVO

3 MATERIAIS E MÉTODOS___ 37

3.1 Soluções e Tampões___ 38

3.1.1 Soluções para tratamentos dos animais___ 38

3.1.2 Extratos das glândulas salivares _ 38

3.1.3 Eletroforese em gel de poliacrilamida na presença de SDS Unidimensional__ 38

3.1.4 Eletroforese em gel de poliacrilamida na presença de SDS Bidimensional __ 38

3.1.5 Digestão das proteínas em gel__ 39

3.2 Drogas e Reagentes __ 39

3.3 Animais e grupos experimentais __ 440

3.4 Glândulas Salivares__ 40

3.5 Preparo dos extratos das glândulas salivares ___ 41

3.5.1 Extrato para realização de Eletroforese Unidimensional (1-DE) __ 41

3.5.2 Extrato para realização de Eletroforese Bidimensional (2-DE) __ 41

3.6 Dosagem de proteínas __ 41

3.7 Análise Proteômica __ 42

3.7.1 1-DE em gel de poliacrilamida na presença de SDS (SDS-PAGE) ___ 42

3.7.2 2-DE em gel de poliacrilamida na presença de SDS (SDP-PAGE) __ 42

3.7.2.1 Reidratação das Fitas e Focalização isoelétrica (primeira dimensão) ___ 42

3.7.2.2 Equilíbrio das fitas __ 43

3.7.2.3 Gel de poliacrilamida na presença de SDS (SDS-PAGE) (segunda dimensão) _ _ 43

3.7.2.4 Digestão das proteínas em gel __ 44

3.7.2.5 Identificação das proteínas por nanocromatografia acoplada ao espectrômetro de massas de alta resolução nanoeletrospray (nESI-LTQ/Orbitrap) ___ 45

3.7.2.6 Análise dos dados __ 46

4 RESULTADOS _ _ 47 
4.1 Importância do Sistema Nervoso Simpático na composição proteica das glândulas salivares de camundongos 48

4.1.1 Glândulas Submandibulares _ـ 48

4.1.1.1 Análise dos perfis proteicos após 1-DE__ 48

4.1.1.2 Análise dos perfis proteicos após 2-DE__ 49

4.1.1.3 Identificação das proteínas reguladas pela inervação simpática em glândulas submandibulares de camundongos___ 51

4.1.2 Glândulas Parótidas __ 64

4.1.2.1 Análise dos perfis proteicos após 1-DE__ 64

4.1.2.2 Análise dos perfis proteicos após 2-DE___ 66

4.1.2.3 Identificação das proteínas reguladas pela inervação simpática em glândulas parótidas de camundongos___ 67

5 DISCUSSÃO _ 73

6 CONCLUSÃO__ _ 81

REFERÊNCIAS _ 83

APÊENICE $\boldsymbol{A}$ - Table 1: Proteins identified from highest density specific spots of the 2-DE of submandibular gland of the mouse in control group by nESI-LTQ/Orbitrap.___ 93

$\boldsymbol{A P} \hat{\boldsymbol{E} N D I C E} \boldsymbol{B}$ - Table 2: Proteins identified from highest density specific spots of the 2-DE of submandibular gland of the mouse in reserpine-treated group by nESI-LTQ/Orbitrap. 93 AP $\hat{E} N D I C E$ C - Table 3: Proteins identified from highest density specific spots of the 2-DE of submandibular gland of the mouse in reserpine plus adrenoceptor agonists-treated group by nESI-LTQ/Orbitrap.

APÊEDICE D - Table 4: Proteins identified from highest density specific spots that had their densities increased after chronic treatment with reserpine of the 2-DE of submandibular gland of the mouse present in all the 3 groups by nESI-LTQ/Orbitrap. 93

$\boldsymbol{A P} \hat{\boldsymbol{E} N D I C E} \boldsymbol{E}$ - Table 5: Proteins identified from highest density specific spots that had their densities reduced after chronic treatment with reserpine of the 2-DE of submandibular gland of the mouse present in all the 3 groups by nESI-LTQ/Orbitrap. 93

AP $\hat{E} N D I C E F$ - Table 6: Proteins identified from highest density spots of the 2-DE of submandibular gland of the mouse in common control and the reserpine + phenylephrine + isoprenaline-treated group by nESI-LTQ/Orbitrap. 93

APÊEDICE $\boldsymbol{G}$ - Table 7: Proteins identified from highest density specific spots of the 2-DE of parotid gland of the mouse in control group by nESI-LTQ/Orbitrap. 93 
APÊEDICE $\boldsymbol{H}$ - Table 8: Proteins identified from highest density specific spots of the 2-DE of parotid gland of the mouse in reserpine-treated group by nESI-LTQ/Orbitrap. 94

APE $\hat{E}$ DICE I - Table 9: Proteins identified from highest density specific spots of the 2-DE of parotid gland of the mouse in reserpine plus adrenoceptor agonists-treated group by nESI-LTQ/Orbitrap. 


\section{INTRODUÇÃO}




\subsection{Glândulas Salivares}

As glândulas salivares são glândulas exócrinas que estão localizadas na cavidade oral e tem como principal função a síntese e secreção de saliva, um fluido complexo composto por água e uma multiplicidade de substâncias, incluindo íons, proteínas e glicoproteínas, que tem por função umedecer e lubrificar a boca e os alimentos. Além disso, a saliva secretada pelas glândulas salivares contém enzimas que iniciam o processo de digestão, como exemplo, podemos citar a digestão de glicídios pela amilase presente na saliva (SARACCO; CRABILL, 1993).

As glândulas salivares desenvolvem-se a partir do epitélio bucal por uma invaginação das células epiteliais para o interior do tecido mesenquimal subjacente, ramificando-se em um padrão arborizado, formando estruturas semelhantes a "brotos" que vão crescendo e diferenciando-se em lóbulos, originando assim as unidades secretoras. As protuberâncias epiteliais dão origem aos ductos alveolares e aos componentes das glândulas, enquanto que os vasos sanguíneos e o estroma são derivados de tecidos mesenquimais (SARACCO; CRABILL, 1993).

As glândulas salivares são usualmente divididas em dois grupos, as glândulas salivares menores (ou pequenas) e as glândulas salivares maiores. As glândulas salivares menores são numerosas, estão localizadas em regiões específicas da cavidade oral e dentre essas glândulas estão as glândulas linguais anteriores e posteriores, as glândulas labiais, glândulas molares, glândulas incisivas e as glândulas do palato. As glândulas menores encontram-se na lâmina própria ou na submucosa da cavidade oral e liberam os seus produtos para a cavidade oral através de numerosos canais excretores curtos. Essas glândulas secretam pequenos volumes de saliva rica em mucina, sendo que essa secreção não é influenciada por estímulos reflexos, isto é, não ocorre aumento do fluxo salivar em resposta à alimentação como ocorre nas glândulas salivares maiores (CARPENTER, 2013). Embora as glândulas menores contribuam com apenas cerca de $10 \%$ do conteúdo de secreção salivar, essas glândulas são importantes na manutenção de uma rica camada de mucina adjacente à mucosa (CARPENTER, 2013).

Dentre as glândulas salivares maiores estão as glândulas parótidas, as submandibulares e as sublinguais. Essas glândulas são pareadas e são responsáveis pela secreção de 90 \% da saliva basal total, sendo que as glândulas submandibulares secretam em torno de 60 a 70 \% desse total, as parótidas são responsáveis por 25 a $35 \%$ e as sublinguais secretam em torno de 
5 \% (HAND, $1986^{1}$ apud SARACCO; CRABIL, 1993). Entretanto, a glândula parótida contribui mais significativamente para a saliva total quando estimulada por paladar ou mastigação, ou seja, ela é mais responsiva à variação de dieta do que a glândula submandibular ou a sublingual (MATSUO, 2000).

As glândulas salivares maiores são usualmente classificadas como glândulas túbuloacinares compostas (TANDLER, 1978; WILBORN; SHACKLEFORD, 1980). De acordo com Pinkstaff (1993), descrever uma glândula como tubulo-acinar implica que existem dois tipos diferentes de componentes na porção secretora dessa glândula, os túbulos e os ácinos, além disso, o termo composta significa que as porções secretoras da glândula liberam seu conteúdo através de um sistema ramificado de ductos.

As unidades secretoras das glândulas salivares são formadas por 2 tipos principais de componentes: os ácinos e os ductos (Figura 1). Os ácinos são estruturas que apresentam diversidade de tamanho, forma e número de células, compostos por células acinares secretoras responsáveis pela síntese e secreção da maior parte das proteínas funcionalmente importantes da saliva (PROCTOR, 1998; SEGAWA; YAMASHINA, 1998).

Os ductos são responsáveis pela modificação e transporte da saliva até alcançarem a boca. Na maioria dos mamíferos, as glândulas salivares apresentam ductos intercalares (ID) que recebem os produtos sintetizados pelas células secretoras. Esses ductos transferem o conteúdo secretado para ductos estriados (SD), e estes para os ductos excretores (ED) (Figura 1). Finalmente, os ductos excretores coalescem para formar um ducto excretor principal, ou em algumas glândulas, em múltiplos ductos excretores principais (PINKSTAFF, 1993; TANDLER, 1993).

Os IDs têm comprimento variável, são formados por células escamosas próximas às células cuboides e possuem a função de modificar a saliva primária quando ela é conduzida através desse segmento de ductos. Os SDs de glândulas parótidas e submandibulares de humanos e roedores são morfologicamente semelhantes e possuem células colunares altas ricas em mitocôndrias alongadas, com interdigitações de sua membrana basal e pequenas células basais ocasionais. Os EDs das glândulas submandibulares e parótidas de humanos apresentam células secretoras similares às observadas nos SDs e parecem estar envolvidos no transporte de fluidos e elétrons (PINKSTAFF, 1980, 1993).

\footnotetext{
${ }^{1}$ HAND, A. Salivary glands. In: BOHASKAR, S. N. (Ed.). Orban's oral histology and embryology. St. Louis: C. V. Mosby. 1986. v. 3454.
} 
Glândulas submandibulares de ratos e roedores apresentam ainda ductos granulares (GD) localizados entre os IDs e os SDs. As células desses ductos são colunares, contêm poucas mitocôndrias localizadas nas regiões basais, apresentam grande quantidade de retículos endoplasmáticos granulosos e números grânulos secretórios apicais (PINKSTAFF, 1993).

No entanto, comparando vários mamíferos, Tandler (1993) mostrou que os sistemas de ductos das glândulas salivares variam entre as espécies animais e que além de modificar e transportar a saliva até a boca, eles podem adicionar material orgânico à saliva.

Além das células com funções de síntese e secreção de proteínas, outro tipo celular também identificado no parênquima da maioria das glândulas salivares são as células mioepiteliais, as quais se localizam junto aos ácinos e ductos, interpostas no espaço entre a membrana basal e a membrana plasmática (Figura 1). As células mioepiteliais estão presentes em todas as glândulas salivares maiores de humanos e camundongos. (GARRETT; EMMELIN, 1979; PINKSTAFF, 1993; RAUBENHEIMER; NIEKERK; HAUMAN, 1987; SHEAR, 1966). Geralmente, essas células não são secretoras e possuem características morfológicas tipicamente encontradas em células contrácteis, tais como os miofilamentos. Tendo em vista a presença desses miofilamentos citoplasmáticos proeminentes, é sabido que essas células possuem natureza contrátil e, desempenham um papel importante na propulsão da secreção. Além disso, as células mioepiteliais dão suporte para os ácinos e também podem ajudar o processo de exocitose das secreções no sistema de ductos (PROCTOR; CARPENTER, 2007). As células mioepiteliais possuem uma dupla inervação parassimpática e simpática e os impulsos de ambos os tipos causam contração (GARRETT; EMMELIN, 1979). 
Figura 1 - Representação diagramática dos compartimentos das glândulas salivares maiores.

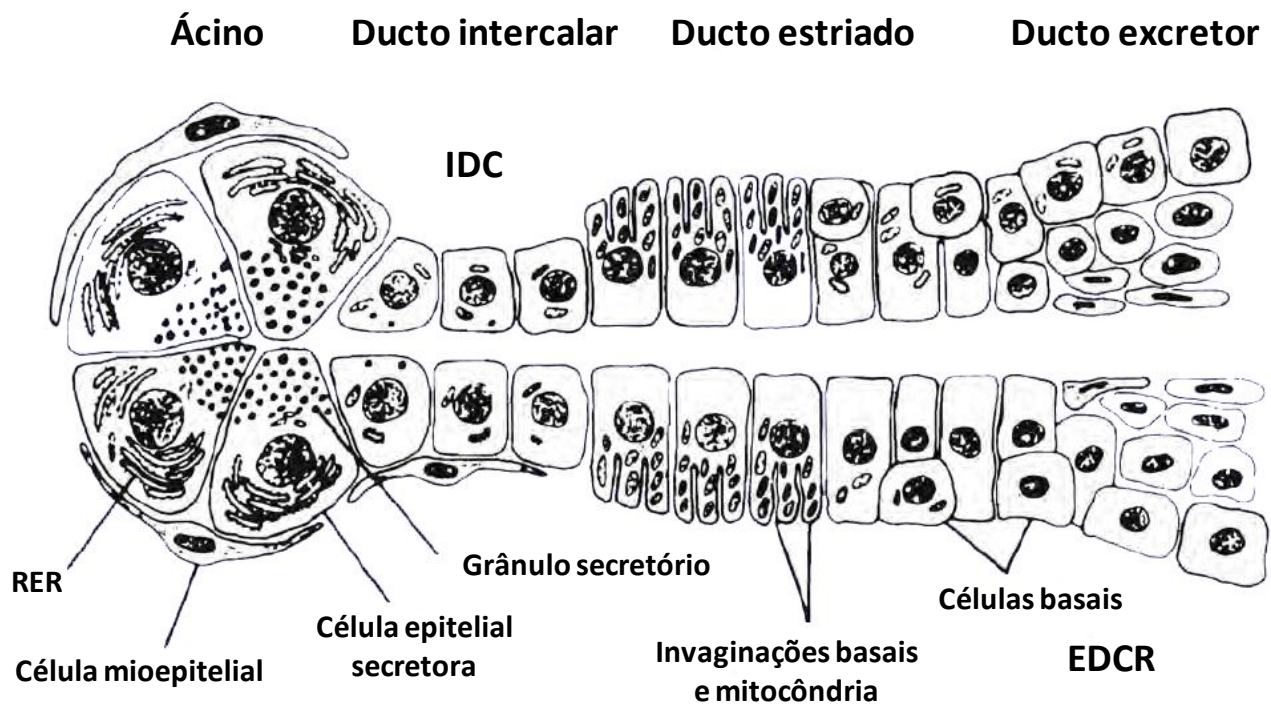

Porção secretora de uma glândula salivar, destacando-se a unidade secretora (ácino) e o sistema de ductos. IDC: células do ducto intercalar. EDRC: células do ducto excretor.

Fonte: (RAUBENHEIMER; NIEKERK; HAUMAN, 1987).

As células secretoras das glândulas salivares são classicamente descritas como serosas, mucosas ou seromucosas, dependendo do tipo de glândula salivar. Essas células exibem aspectos histológicos distintos, sendo que as células mucosas apresentam estrutura piramidal com núcleo achatado localizado na sua base. Já as células serosas são piramidais com núcleos esféricos localizados nos terços basais (PINKSTAFF, 1993).

Ainda, os ácinos podem apresentar os 2 tipos de células secretoras juntas, e nesse caso, são denominados como ácinos mistos, e podem ser vistos em glândulas submandibulares e sublinguais de alguns mamíferos. Em um ácino misto, as células mucosas formam uma estrutura acinar típica, com extremidade em fundo de saco, revestidas por células tipicamente serosas ou seromucosas, arranjadas como semi-luas. A secreção das células semi-luas serosas alcança o lumen através de canalículos intercelulares (PINKSTAFF, 1993).

A glândula submandibular é uma glândula tubulo-acinosa mista, cuja porção secretora é constituída de células mucosas e serosas. As células serosas, que são os principais componentes das glândulas, agrupam-se formando ácinos, podendo também associar-se às células mucosas acinares, onde se colocam excentricamente, formando células semi-luas (WILCOX; PINKSTAFF, 1982). De acordo com Barka (1980), as glândulas submandibulares 
de ratos e camundongos apresentam ductos intralobulares, os quais possuem grânulos elétrondensos que contêm uma grande quantidade de polipeptídeos biologicamente ativos.

Já a glândula parótida é uma glândula acinosa composta, cuja porção secretora é constituída praticamente por células serosas que contêm grande quantidade de grânulos de secreção ricos em proteínas (grânulos de zimogênios) e elevada atividade de amilase.

Os processos de síntese e secreção nas células secretoras são similares, porém os produtos secretados possuem composições distintas (TEN CATE, 2001). Os ácinos são especializados para cada tipo de glândula e classificados de acordo com os seus produtos secretados, refletindo na composição da saliva. Da mesma forma que as dietas variam entre uma espécie para outra, as glândulas salivares de diferentes animais são especializadas para cada dieta (TANDLER; PHILLIPS, 1998). Dessa forma, a composição final da saliva, bem como da saliva primária, é possivelmente única para cada glândula salivar e é determinada pela natureza das células secretoras dos ácinos e pelos elementos dos ductos. Ainda, existem diferenças significativas entre as glândulas salivares de diferentes espécies, bem como entre as diferentes glândulas salivares de uma mesma espécie (PINKSTAFF, 1993).

A saliva primária, produzida pelas células secretoras acinares, contém mucina, enzimas, imunoglobulinas, fatores de crescimento, entre outros compostos (PINKSTAFF, 1993). A água e os eletrólitos são transportados ativamente pelas células acinares e depois o teor eletrolítico é modificado principalmente com a remoção do cloreto de sódio durante a passagem pelo sistema de ductos até chegar à boca (MELVIN et al., 2005; TURNER; SUGIYA, 2002). Durante a passagem pelo sistema de ductos, a saliva isotônica é transformada em saliva hipotônica, a qual auxilia na detecção de sal na dieta. Além de removerem os íons, os ductos adicionam potássio e bicarbonato e este último é responsável pelo sistema de tamponamento da saliva que impede a destruição dos dentes por bactérias produtoras de ácido.

Ainda, além de modificarem a saliva, as células dos ductos também secretam apenas pequenas quantidades de proteína. Por exemplo, as células de ductos granulares, de glândulas submandibulares de alguns roedores, secretam grande quantidade de calicreínas (PROCTOR; CARPENTER, 2007). 


\subsection{Controle Nervoso das Glândulas salivares}

A secreção salivar é um processo contínuo que é regulado por ação reflexa estimulada pelo paladar e pela mastigação ou por outros estímulos através de vários receptores tais como receptores gustatórios, olfatórios, mecanoceptorese e nociceptores (para revisão ver PROCTOR; CARPENTER, 2007). Os impulsos nervosos na via aferente do reflexo salivar vão para o núcleo salivar na medula oblongata. Os nervos eferente parassimpáticos conduzem o sinal para a glandula salivar, enquanto que os nervos projetados da medula prosseguem via nervo cervical simpático superior até o gânglio cervical simpático superior, onde fazem sinapses, prosseguindo então pelas fibras eferentes até as glândulas submandibulares e parótidas (ELVERDIN et al., 1994; GARRETT; ANDERSON, 1991; MORENO et al., 1986) (Figura 2).

Figura 2 - Secreção salivar reflexa.

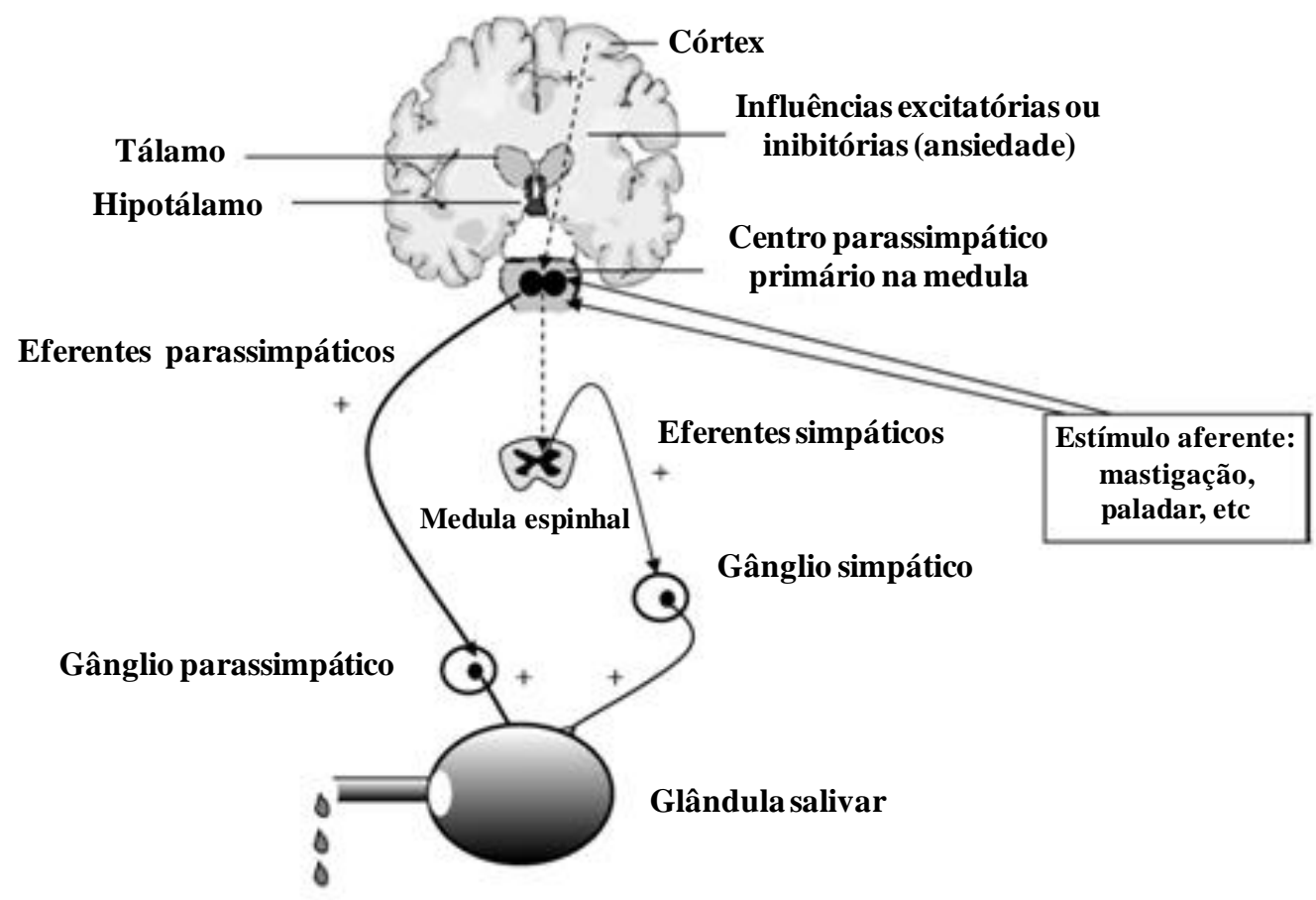

Estímulos aferentes são integrados nos centros salivares primários da medula. Nervos parassimpáticos eferentes conduzem sinais para as glândulas salivares via gânglio parassimpático situado perto da glândula. Projeção nervosa (linha tracejada inferior) parte da medula para o centro simpático nos segmentos torácicos superiores da medula espinhal e a partir daí os nervos simpáticos eferentes direcionam sinais para as glândulas salivares, através do gânglio cervical posterior. Projeções nervosas (linha tracejada superior) partem do córtex para o centro parassimpático na medula, podendo ter efeito excitatório ou inibitório sobre a secreção salivar. Nervos eferentes estimulam a secreção e não há inibição periférica da secreção via inervação simpática.

Fonte: (PROCTOR; CARPENTER, 2007). 
Todas as glândulas salivares são densamente inervadas por nervos simpáticos e parassimpáticos que agem sinergicamente para estimular o processo de síntese e secreção (GARRETT, 1982). Essas inervações podem atuar nos vasos sanguíneoscontrolando o fluxo desangue para as glândulas, nas células mioepiteliais promovendo contração e facilitando a secreção ou nos ácinos e ductos das glândulas salivaresiniciando a formação desalivaprimáriae afetando a absorção e secreção de certos íons nos ductos, respectivamente, além de estimularem exocitose de grânulos contendo macromoléculas, tais como amilase nos ácinos e calicreína nos ductos (Figura 3). A perda dessa inervação pode levar à atrofia e diminuição da capacidade máxima de secreção (EMMELIN, 1981).

Figura 3 - Desenho esquemático da distribuiçãodenervos paraos diferentes efetores deuma glândulasalivar.

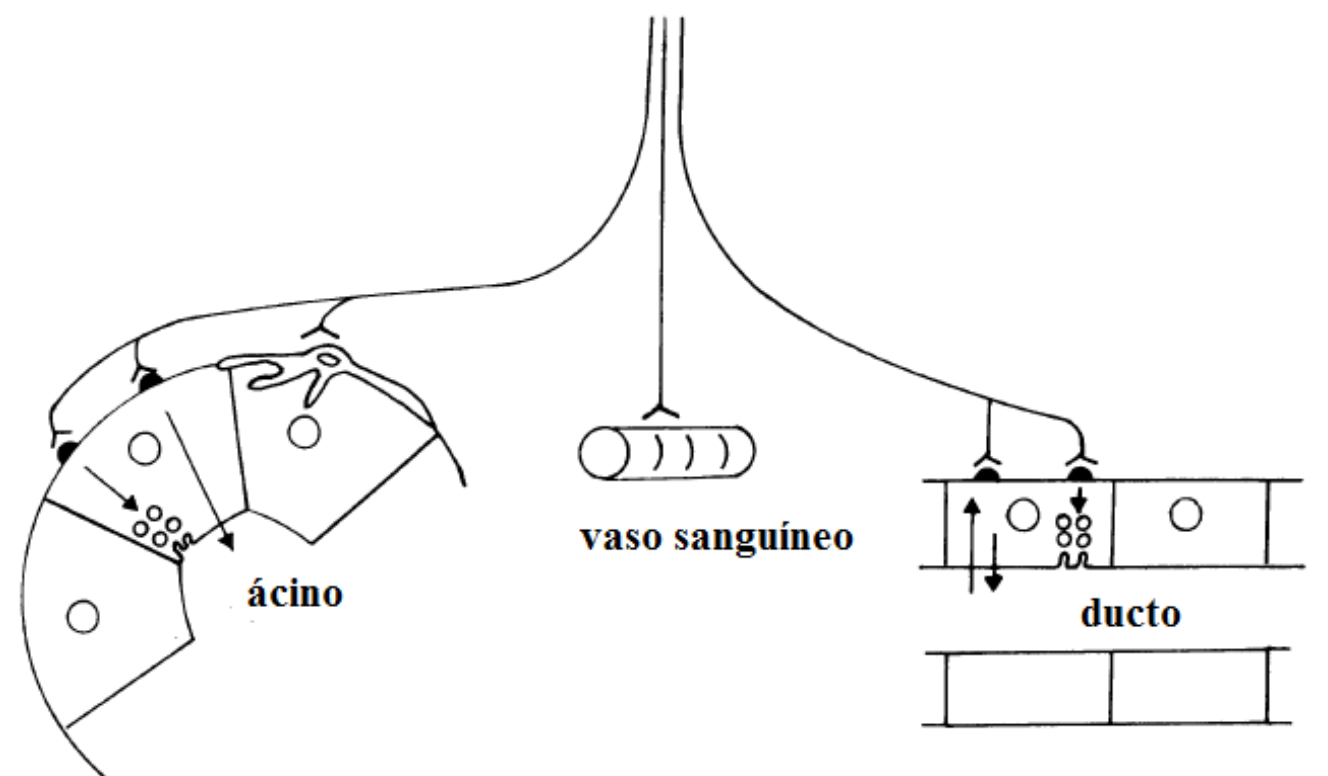

Glândulas salivares possuem um rico suprimento de nervos simpáticos e parassimpáticos. Nervos vasomotores controlam o fluxo sanguíneo, nervos motores contraem as células mioepiteliais e nervos secretores iniciam a formação de proteínas e da saliva primária nos ácinos e atuam na absorção de íons e no transporte de proteínas nos ductos.

Fonte: (EMMELIN, 1981). 
A estimulação da inervação parassimpática provoca secreção abundante de saliva, muito aquosa e com baixa concentração de proteína (BAUM, 1987; GARRETT, 1987; SCHNEYER et al., 1972), enquanto que a estimulação da inervação simpática frequentemente promove a secreção de saliva mais viscosa, rica em proteínas causando pouca mobilização de fluidos, tende a modular a composição da saliva pelo aumento da exocitose das vesículas secretoras das células salivares e induz contração das células mioepiteliais, de modo que a contração dessas células leva à liberação da saliva (GARRETT, 1987; PROCTOR; CARPENTER, 2007). Por exemplo, foi visto que em células acinares de glândulas parótidas de ratos, a estimulação simpática causa um baixo fluxo de saliva, porém rico em amilase, acompanhado por uma extensiva desgranulação, onde os grânulos secretórios migram para a região apical para serem exocitados (GARRETT; THULIN, 1975).

Os efeitos dosimpulsos nervosossimpáticos e parassimpáticossobre a secreção de proteínas pelasglândulassalivarespodem diferirentre as diferentes glândulas de uma mesma espécie, bem como a mesma glândula entre espécies diferentes.Ambas as inervações exercem seus efeitos sobre a secreção de proteínas nas células secretoras dos ácinos, nas células semilua e nas células do ducto.Asquantidades (volume) e a composição das proteínassecretadas a partir decada tipo de céluladiferem dependendo donervo que está sendoestimulado (PROCTOR; CARPENTER, 2007).

Um conjunto de neurotransmissores é liberado a partir das terminações nervosas simpáticas e parassimpáticas, os quais, subsequentemente, irão ativar receptores específicos nas membranas basolaterais das células epiteliais salivares (BAUM, 1987; GARRETT, 1982). Esses neurotransmissores são os principais estímulos externos para a secreção das glândulas e são os primeiros mensageiros implicados na regulação celular da síntese de proteínas e da exocitose. Os principais neurotransmissores liberados pelas inervações parassimpáticas e simpáticas são a acetilcolina e a noradrenalina, respectivamente. Esses neurotransmissore s estimulam a secreção das glândulas salivares através da sua ligação a receptores específicos presentes nas membranas basolaterais,desencadeando complexas sinalizações intracelulares que levam à síntese ou secreção de proteínas da saliva, bem como proteínas das glândulas salivares. Além de acetilcolina e noradrenalina, outros neurotransmissores importantes incluem vários neuropeptídios, sendo que o polipeptídio vasoativo intestinal (VIP) e a substância P são liberados pelo sistema nervoso parassimpático, e o neuropeptídio Y, o qual é secretado pela inervação simpática (BAUM, 1987, 1993; BAUM; WELLNER, 1999; 
EKSTROM, 1987; EKSTROM et al., 1989; PELUSO et al., 2007, para revisão ver PROCTOR; CARPENTER, 2007; WRIGTH; LUEBKE, 1989).

A acetilcolina liberada pelos nervos parassimpáticos, atuando em receptores muscarínicos M1 e M3, contribui para a secreção total da saliva (GAUTAM et al., 2004; NAKAMURA et al., 2004). Esses receptores estão acoplados à proteína $G_{q}$, e quando estimulados levam à ativação da fosfolipase $\mathrm{C}$ e consequente liberação de $\mathrm{IP}_{3}$ e diacilglicerol, levando a um aumento na concentração de cálcio citosólico (STREB et al., 1983).

Já a noradrenalina, liberada pelos nervos simpáticos, estimula a secreção salivar através da sua ligação aos adrenoceptores alfa $a_{1}$ e beta ${ }_{1}$. Os adrenoceptores alfa $a_{1}$ sinalizam da mesma forma que os receptores muscarínicos M1 e M3, ao passo que os adrenoceptores beta sinalizam através da proteína $\mathrm{G}_{\mathrm{s}}$ levando à ativação da adenilciclase, com posterior elevação da concentração de AMP cíclico intracelular e estimulação de uma proteína cinase dependente de AMP cíclico, PKA e fosforilação de proteínas endógenas que levam à exocitose das vesículas e consequentemente, secreção de proteínas na saliva (PROCTOR; CARPENTER, 2007). De acordo com dados da literatura, a via dependente de AMP cíclico geralmente representa o principal mecanismo para estimulação da exocitose das proteínas secretadas, enquanto a via relacionada à ativação da fosfolipase $\mathrm{C}$ é mais importante para o controle da secreção de água e eletrólitos. (BAUM et al., 1981; GARRETT et al., 1991; WOON; JEYASEELAN; THIYAGARAJAH, 1993).

No entanto, foi mostrado que a estimulação dos adrenoceptores alfa não regula somente a secreção de eletrólitos, mas também de amilase e mucinas (KLEIN, 2002; QUISSELL et al., 1993). Ambos os subtipos de adrenoceptores alfa ${ }_{1 \mathrm{~A}}$ e alfa $_{1 \mathrm{~B}}$ são expressos em glândulas submandibulares de ratos e humanos, entretanto, foi detectada uma maior concentração do RNAm do subtipo alfa ${ }_{1 \mathrm{~A}}$ do que alfa $\mathrm{a}_{1 \mathrm{~B}} \mathrm{em}$ ambas as glândulas, indicando uma similaridade no padrão de expressão dos subtipos do adrenoceptor alfa 1A $_{\mathrm{A}}$ em ratos e humanos (HUANG et al., 2006; NISHIURA et al., 2001). A estimulação dos adrenoceptores alfa $a_{1}$ desencadeia uma sinalização celular que leva a um aumento na concentração de cálcio intracelular, contribuindo para a regulação da produção e secreção da saliva (HUANGet al., 2006; para revisão ver QUISSEL et al.,1992). Além disso, estudos em coelhos com glândulas submandibulares transplantadas mostraram que o tratamento com fenilefrina, um agonista do adrenoceptor alfa melhora as lesões estruturais e a função secretora destas glândulas (XIANG et al., 2006). Foi visto também que em camundongos, as glândulas submandibulares liberamEGF na saliva após estimulação aguda do adrenoceptor alfa, mas tratamento com 
repetidas doses de fenilefrina diminui a quantidade de EGF dessas glândulas. Observou-se ainda que administração crônica de fenilefrina induz um aumento progressivo no peso das glândulas parótidas e submandibulares (CAMPRECIÓS et al., 2009).

Tratamento crônico com isoprenalina, agonista do adrenoceptor beta, leva à ativação do adrenoceptor beta, o qual tem uma participação importante na expressão e secreção de proteínas da saliva e no desenvolvimento pós-natal em glândulas salivares (EKFORS et al., 1972; SHAW et al., 1990). Ativação dos adrenoceptores beta também leva à produção de AMPc e à ativação de proteínas cinases dependentes de AMPc, estimulando, por exemplo, a cascata das MAPKs (QUISSELL et al., 1992). Os subtipos beta 1 e beta 2 são expressos na glândula submandibular de coelhos, sendo que o subtipo beta ${ }_{1}$ é predominante e participa da regulação da secreção de saliva, especialmente na síntese e secreção de proteínas da saliva (LI et al., 2006). Animais tratados cronicamente com isoprenalina tiveram um massivo aumento na secreção proteica observada nas glândulas parótidas (BOGART, 1975). Foram observadas também alterações na expressão gênica da glândula parótida de camundongos após o tratamento crônico com isoprenalina (TEN HAGEN et al., 2002). Ainda, a importância da estimulação dos adrenoceptores beta em glândulas salivares não está somente em promover a secreção de saliva, mas também em promover a síntese de proteínas da saliva (BAUM; WELLNER, 1999). Também é sabido que o tratamento crônico com isoprenalina leva a um tamanho das células acinares de glândula parótida (D’AMICO et al., 2010). Ann e Lin (1998) mostraram que esse crescimento adaptativo das glândulas submandibulares e parótidas é resultado do aumento celular e de uma resposta proliferativa moderada da diferenciação das células acinares, sendo ainda que esse aumento de tamanho das glândulas salivares está associado a alterações qualitativas e quantitativas na expressão gênica salivar.

Para desvendar as funções do sistema nervoso simpático nas glândulas salivares, muitos estudos utilizam como ferramenta farmacológica a reserpina, uma droga simpatolítica que depleta as reservas de catecolaminas nas terminações nervosas e não nervosas por bloquear a ligação da noradrenalina às vesículas sinápticas (MARTINEZ-OLIVARES et al., 2006; STITZEL, 1977).

O tratamento crônico com reserpina promove alterações morfológicas e funcionais irreversíveis, similares às alterações encontradas em pacientes com fibrose cística (MARTINEZ et al., 1975a,b; WATSON et al., 1984). De acordo com Watson et al. (1984), a reserpinização crônica altera a função da glândula parótida através da diminuição dos níveis de AMPc e GMPc. Além disso, administração crônica de reserpina leva a uma redução da 
resposta promovida pela estimulação noradrenérgica e mudanças na composição da saliva (MARTINEZ et al., 1975a,b). Tratamento crônico com reserpina também leva a um aumento do número de adrenoceptores beta e diminuição da atividade fosfodiesterásica, provavelmente devido à diminuição dos níveis de AMPc na glândula submandibular de ratos (BYLUND et al., 1981).

\subsection{Glândula de Veneno da serpente Bothrops jararaca}

Paralelo com a evolução da dentição ocorreu a evolução da glândula de veneno, provavelmente a partir de estruturas salivares especializadas do lábio superior e a evolução do músculo compressor de glândula, derivado da musculatura temporal anterior (KARDONG, 1982). As serpentes Viperidae possuem um par de glândulas de veneno que se localizam na região temporal, posterior aos olhos, embaixo da pele, sendo uma de cada lado da cabeça (Figura 4A) (KOCHVA; GANS, 1967; MELGAREJO, 2003).

Assim como as glândulas salivares de mamíferos, glândulas de veneno das serpentes Viperidae são glândulas orais exócrinas e são capazes de secretar proteínas tóxicas (KOCHVA; GANS, 1970). Essas glândulas de veneno têm a característica de possuir um lumen central onde o veneno produzido é armazenado e um longo ciclo de produção de veneno que leva de 30 a 50 dias para se completar, com fases distintas que incluem um estágio de ativação após a perda do veneno do lumen e um estágio quiescente quando o lumen está cheio de veneno (MACKESSY, 1991; KOCHVA, 1987; KOCHVA; GANS, 1970; WARSHAWSKY et al., 1973; YAMANOUYE et al., 2000), diferentemente das glândulas salivares que estão constantemente ativadas (Figura 4B). 
Figura 4 - Glândula de veneno de serpentes Viperidae.
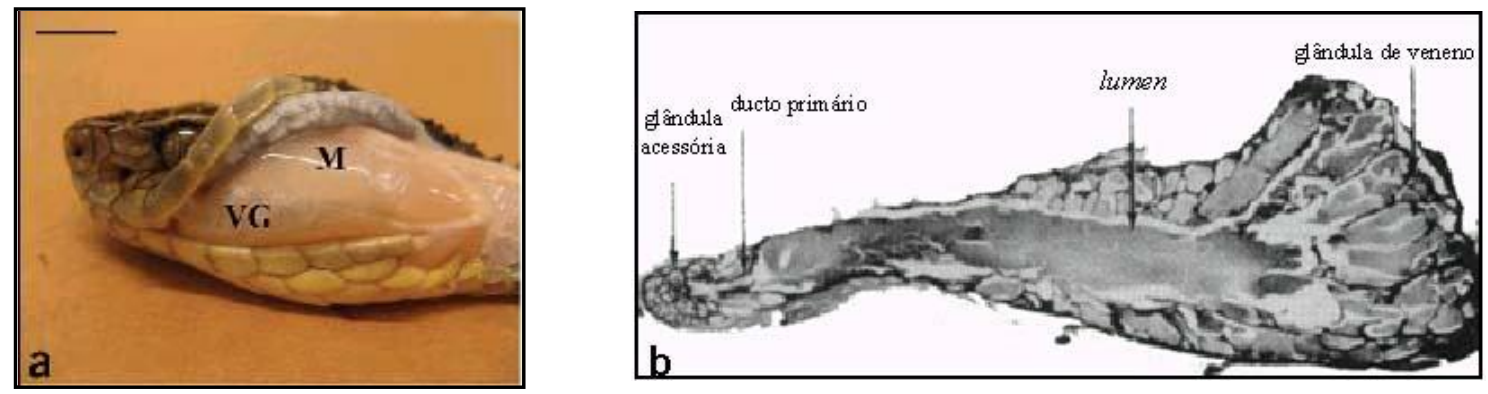

(A) vista lateral da cabeça da serpente Bothrops jararaca, mostrando a localização da glândula de veneno. VG: glândula de veneno, M: músculo compressor de glândula. (B) corte sagital do aparelho glandular de veneno da serpente Vipera palaestinae.

Fonte: A (YAMANOUYE et al., 2007) B (KOCHVA, 1987).

O processo de produção e secreção de veneno ocorre após uma diminuição do conteúdo do lumen da glândula, seja após uma picada ou por extração manual de veneno, e é acompanhada por mudanças morfológicas e bioquímicas no epitélio secretor da glândula de veneno (BDOLAH, 1979; CARNEIRO et al., 1991; KOCHVA, 1978; MACKESSY, 1991; SALOMÃO, 1991). Após a extração, a quantidade de veneno no lúmen diminui iniciando-se um novo ciclo de síntese de veneno, em que as células epiteliais passam da forma cubóide para uma forma colunar, as cisternas do retículo endoplasmático se expandem e o veneno é sintetizado.

De acordo com estudos feitos por Yamanouye et al. (1997), foi demonstrado que a inervação noradrenérgica está envolvida na produção e secreção de veneno de Bothrops jararaca, uma vez que o bloqueio da atividade simpática por reserpina bloqueou a produção e secreção de veneno em glândulas ativadas pela extração de veneno. A estimulação de ambos os adrenoceptores alfa e beta está envolvida nesse processo, pois ainda segundo descrito por Yamanouye et al. (1997), a administração de isoprenalina e fenilefrina é capaz de reverter a ação da reserpina, restaurando a síntese proteica do veneno mas apenas a fenilefrina é capaz de restaurar o processo de secreção de proteínas do veneno.

Dados anteriores do laboratório mostraram também que após a extração de veneno, a noradrenalina é liberada e atuando em adrenoceptores alfa e beta ativa a glândula de veneno (KERCHOVE et al., 2004; LUNA et al., 2009; ZABLITH, 2007). A ativação desses receptores desencadeia uma complexa sinalização intracelular culminando na ativação de fatores de transcrição NFאB e AP-1 que irão regular a síntese de proteínas da glândula de 
veneno, as quais são essenciais para a sua ativação e funcionamento (KERCHOVE et al., 2008; LUNA et al., 2009; YAMANOUYE et al., 2000, ZABLITH, 2007).

Ainda, analisando-se o ciclo de produção do veneno estimulado pela inervação noradrenérgica após a extração de veneno, Luna et al. (2009) mostraram através de análises após eletroforese unidimensional, que a extração de veneno promove mudanças no perfil proteico da glândula de veneno, sendo que as diferenças mais significativas foram 4 e 7 dias após a extração de veneno em serpentes fêmeas e machos, respectivamente. O tratamento com reserpina bloqueou essas mudanças e a administração concomitante de agonistas de adrenoceptores alfa e beta restaurou o efeito de reserpina, levando à ativação da glândula de veneno e consequentemente à produção de veneno (LUNA et al., 2009).

\subsection{Importância da saliva}

A cavidade bucal está relacionada com diversas atividades fisiológicas dos mamíferos, entre elas a mastigação, deglutição, fonação e gustação. A saliva, secretada constantemente nesta cavidade, é de fundamental importância para a manutenção da saúde bucal, atuando em fatores tais como o tamponamento de $\mathrm{pH}$, remineralização dental e prevenção de infecções.

A saliva tem inúmeras funções. Além umedecer os tecidos orais e auxiliar na deglutição (SARACCO; CRABILL, 1993), a saliva é crucial para manter a integridade da superfície da mucosa oral (HAY; BOWEN, 1999). A secreção salivar atua ainda no controle de outras variáveis fisiológicas e comportamentais como a termorregulação e ingestão de sódio (FERGUSON, 1993; JENSEN et al., 1991).

A importância da inervação para produção de saliva é claramente demonstrada na xerostomia que é um dos sintomas dos distúrbios das glândulas salivares, caracterizada pela diminuição do volume de saliva na cavidade bucal. A xerostomia pode ocorrer em resposta a várias condições, incluindo reações adversas a medicamentos e estresse (DANIELS; WU, 2000), bem como ser decorrente de disfunções das glândulas salivares como a síndrome de Sjögren, que leva à deteriorização da membrana mucosa da boca e da traquéia (BROSKY, 2007; VON BÜLTZINGSLÖWEN et al., 2007), podendo resultar em uma maior ou menor inibição da ação das glândulas salivares, afetando o sistema salivar em diferentes níveis (MANDEL; WOTMAN, 1976).

A glândula salivar por si só, pode ter diminuída sua secreção por aplasia, obstrução, infecção, idade, doenças sistêmicas tais como a síndrome de Sjögren e radiação ionizante que levam à degeneração de seus ácinos (GLASS et al., 1984). 
Pacientes com diminuição de secreção salivar total ou parcial devido à radiação na região da face, com exocrinopatia como a síndrome de Sjögren, desidratados, sob o uso excessivo de diuréticos ou de drogas anticolinérgicas ou antiadrenérgicas, exibem sinais e sintomas como boca seca, queimação da mucosa bucal, dificuldade para alimentar-se, desconforto ao falar, aumento no índice de cáries (FERGUSON, 1993; WISEMAN; FAULDS, 1995). Devido a esses efeitos indesejáveis e desagradáveis, a correção ou redução desses problemas com o uso de substâncias que estimulam a secreção salivar, tem, portanto, interesse clínico e farmacológico.

Vários tratamentos têm sido propostos e utilizados no intuito de promover um aumento no fluxo salivar e de melhorar o processo de secreção salivar. Entre eles está o uso de um fármaco estimulador do fluxo salivar, o cloridrato de pilocarpina, droga sialogoga (BROSKY, 2007). Este fármaco tem sido utilizado por estimular os receptores colinérgicos, dentre eles o receptor muscarínico M3 presente nas glândulas salivares, levando a um aumento na produção e liberação da saliva (BERNARDI et al., 2002; FERGUSON, 1993).De acordo com Peluso et al. (2007), estudos proteômicos da saliva mostraram que a pilocarpina é capaz de restaurar parcialmente a densidade e número de proteínas identificáveis na saliva de pacientes com Síndrome de Sjögren.

Em relação à inervação simpática, não existem trabalhos mostrando a importância da estimulação dessa inervação na melhoria dos sintomas da xerostomia. No entanto, como visto por nosso laboratório, a noradrenalina é capaz de ativar a glândula de veneno de serpentes levando à produção e secreção de veneno (KERCHOVE et al., 2004; LUNA et al., 2009; YAMANOUYE et al., 1997, 2000; ZABLITH, 2007). 


\subsection{Relevância}

Devido à relação existente entre glândulas salivares de mamíferos e glândulas de veneno de serpente, os dados obtidos pelo nosso grupo mostrando a importância da inervação noradrenérgica na ativação da glândula de veneno de Bothrops jararaca, tornou-se interessante verificar se a inervação noradrenérgica também é capaz de manter ativadas as glândulas salivares de camundongos, regulando a síntese de proteínas destas glândulas e assim, validar o modelo experimental da glândula de veneno e mostrar que essa glândula é um bom modelo para estudar a regulação fisiológica de glândulas exócrinas.

Além disso, o conhecimento mais aprofundado da função da inervação simpática em glândulas salivares poderá contribuir para os estudos fisiopatológicos de várias disfunções orais humanas, bem como para melhora de alguns procedimentos terapêuticos. 
2 OBJETIVO 
O objetivo desse projeto foi verificar a participação da inervação noradrenérgica na manutenção da ativação das glândulas salivares de camundongos, assim como ocorre na glândula de veneno da serpente Bothrops jararaca e identificar as proteínas que têm a síntese regulada pelo sistema nervoso simpático.

Estratégias:

- Avaliar os efeitos da administração crônica de reserpina na síntese de proteínas das glândulas submandibulares e parótidas de camundongos através da análise proteômica unidimensional e bidimensional;

- Verificar se a ativação dos adrenoceptores alfa e beta pela administração de fenilefrina e isoprenalina é capaz de reverter os efeitos causados pela reserpina.

- Identificar, por espectrometria de massas, as proteínas cujas sínteses são reguladas pela ativação da inervação simpática. 
MATERIAIS E
MÉTODOS 


\subsection{Soluções e Tampões}

\subsubsection{Soluções para tratamentos dos animais}

- Solução Veículo: ácido acético glacial $4 \%$, propilenoglicol $4 \%$, etanol $4 \%$ em água ultra-pura.

- Solução de Reserpina (4 mg/mL): ácido acético glacial $4 \%$, propilenoglicol $4 \%$, etanol $4 \%$ em água ultra pura.

- Solução de Fenilefrina e Isoprenalina: $20 \mathrm{mg} / \mathrm{mL}$ em NaCl 0,6 \% e ácido ascórbico $0,01 \%$.

\subsubsection{Extratos das glândulas salivares}

- Tampão de homogeneização: solução de sacarose 0,32 M, EDTA $1 \mathrm{mM}, \mathrm{MgCl}_{2} 3 \mathrm{mM}$ e coquetel de inibidores de proteases (Sigma P8340, diluição 1:100).

- Tampão de lise: Tris HCl 30 mM pH 8,5; Uréia 7 M, Tiouréia 2 M, Chaps $4 \%$ e coquetel de inibidores de protease (Sigma P8340, diluição 1:100).

\subsubsection{Eletroforese em gel de poliacrilamida na presença de SDS Unidimensional}

- Solução Corante Coomassie R: azul de Coomassie R 0,1 \% em ácido acético 5 \% e metanol $25 \%$.

- Solução Descorante: ácido acético $5 \%$ e metanol $25 \%$.

- Tampão de Amostra 2X (SDS-PAGE): Dodecil Sulfato de Sódio (SDS) 4 \%; glicerol $20 \%$; $\beta$-mercaptoetanol $10 \%$; Tris 50 nM, pH 6,8; azul de Bromofenol 0,05\%.

- Tampão de Corrida: Tris 25 mM; glicina 192 mM; SDS 0,1\%.

\subsubsection{Eletroforese em gel de poliacrilamida na presença de SDS Bidimensional}

- Solução de equilíbrio redutora: Tris $\mathrm{HCl} 50$ mM, pH 8,4, uréia 6 M, SDS $2 \%$, glicerol $30 \%$, ditiotreitol $2 \%$.

- Solução de equilíbrio alquilante: Tris $\mathrm{HCl} 50$ mM, pH 8,4, uréia 6M, SDS 2 \%, glicerol $30 \%$, iodoacetamida $3 \%$. 
- Solução de Agarose: agarose 0,5\% e azul de bromofenol 0,002 \%.

- Solução Corante Coomassie G: sulfato de amônio 8 \%, ácido ortofosfórico $1 \%$, azul de Coomassie G-250 0,1\%.

- Solução Fixadora: ácido acético $5 \%$ e etanol $20 \%$.

- Solução de preservação: ácido acético $5 \%$.

- Tampão de Corrida: Tris 25 mM; glicina 192 mM; SDS 0,1\%.

\subsubsection{Digestão das proteínas em gel}

- Solução descorante: acetonitrila 50 \% e bicarbonato de amônio 25 mM, pH 8,0.

- Solução de tripsina: $20 \mathrm{ng} / \mu \mathrm{L}$ em bicarbonato de amônio 40 mM, pH 8,0.

\subsection{Drogas e Reagentes}

- Azul de Coomassie - Brilliant Blue R: Bio Rad Lab., Hercules, CA, USA.

- Azul de Coomassie - Brilliant Blue G: Bio Rad Lab., Hercules, CA, USA.

- Azul de Bromofenol: Plus one, Uppsala, Sweden.

- Bio-Rad protein assay: Bio Rad Lab., Hercules, CA, USA.

- $\beta$-mercaptoetanol - Molecular Biology Grade: Calbiochem, La Jolla, CA, USA.

- Coquetel inibidor de protease: P 8340, Sigma-Aldrich, St. Louis, MO, USA.

- Hidrocloreto de L-fenilefrina: Sigma-Aldrich, St. Louis, MO, USA.

- Isoprenalina: Sigma-Aldrich, St. Louis, MO, USA.

- Padrão de peso molecular para Eletroforese 1-DE: SDS-PAGE Molecular Weight Standarts, Low Range, Bio Rad Lab., Hercules, CA, USA.

- Padrão de peso molecular para Eletroforese 2-DE: Kaleidoscope, Prestained Standard, Bio Rad Lab., Hercules, CA, EUA.

- Reserpina cristalina: Sigma-Aldrich, St. Louis, MO, USA.

- Solução de reidratação DeStreak: GE Healthcare, Uppsala, Sweden.

- Tampão IPG: GE Healthcare, Uppsala, Sweden.

- Tripsina: Promega Corporation, Madison, WI, USA. 
Todos os demais reagentes utilizados para preparação de tampões e soluções foram provenientes da MERCK (Germany), Sigma-Aldrich (St. Louis, USA) ou GE Healthcare (Uppsala, Sweden).

\subsection{Animais e grupos experimentais}

Foram utilizados camundongos (Swiss) machos, adultos $(25-30 \mathrm{~g}), \mathrm{n}=24$, mantidos no Biotério do Laboratório de Farmacologia do Instituto Butantan, em uma sala com temperatura de $22 \pm 2{ }^{\circ} \mathrm{C}$, com ciclo de luz claro e escuro de 12 horas e receberam ração e água à vontade.

Os animais foram divididos em 3 grupos experimentais: 1) Grupo Controle - animais receberam doses de solução veículo (0,5 mg/kg, i.p.) durante 6 dias consecutivos; 2) Grupo Reserpinizados: administração crônica de reserpina $(0,5 \mathrm{mg} / \mathrm{kg}$, i.p. diariamente) durante 6 dias consecutivos; 3) Grupo Tratados RES + FEN + ISO: administração crônica de reserpina $(0,5 \mathrm{mg} / \mathrm{kg}$, i.p. diariamente) durante 6 dias consecutivos, seguido de administração de uma dose única de fenilefrina $\left(20 \mathrm{mg} / \mathrm{kg}\right.$, i.p.) e isoprenalina $(20 \mathrm{mg} / \mathrm{kg}$, i.p. $)$ no $6^{\circ}$ dia de tratamento.

Após os tratamentos, todos os animais foram deixados em jejum por 24 horas e foram sacrificados por deslocamento cervical no $7^{\circ}$ dia.

Os procedimentos experimentais estão de acordo com as normas do Colégio Brasileiro de Experimentação Animal (COBEA) e foram aprovados pela Comissão de Ética no Uso de Animais do Instituto Butantan (protocolo 640/09) e pela Comissão de Ética em Experimentação Animal do Instituto de Ciências Biomédicas da Universidade de São Paulo.

\subsection{Glândulas Salivares}

Após os tratamentos, os animais foram sacrificados por deslocamento cervical e posteriormente, as glândulas submandibulares e parótidas foram coletadas, pesadas e utilizadas conforme descrito abaixo. 


\subsection{Preparo dos extratos das glândulas salivares}

\subsubsection{Extrato para realização de Eletroforese Unidimensional (1-DE)}

Após terem sido coletadas e pesadas, as glândulas submandibulares e parótidas foram fatiadas na espessura de $250 \mu \mathrm{m}$ (Mcllwain Tissue Chopper, Vibratome Company, Midpoint Drive, O’Fallon, MO) e homogeneizadas utilizando um homogeneizador Dounce (Tissue homogenizer, Thomas Teflon pestle, Swedesboro, NJ, USA) em $150 \mathrm{mg} / \mathrm{mL}$ do tampão de homogeinização e centrifugadas a $14.000 \mathrm{~g}$, a $4{ }^{\circ} \mathrm{C}$ por 40 minutos. Os sobrenadantes foram removidos, aliquotados e congelados a $-80^{\circ} \mathrm{C}$ para posterior análise das proteínas.

\subsubsection{Extrato para realização de Eletroforese Bidimensional (2-DE)}

Após terem sido coletadas, as glândulas submandibulares e parótidas foram maceradas em nitrogênio líquido, homogeneizadas (homogeneizador D.L. MICOF) e lisadas com o tampão de lise gelado (100 mg tecido/mL de tampão de lise). As glândulas maceradas e lisadas foram incubadas, no gelo, por 2 horas sob agitação constante e centrifugadas a 12.000 g por 10 minutos a $4{ }^{\circ} \mathrm{C}$ e os sobrenadantes foram aliquotados e congelados a $-80{ }^{\circ} \mathrm{C}$ para posterior análise das proteínas.

\subsection{Dosagem de proteínas}

A concentração de proteínas dos extratos das glândulas salivares foi determinada pelo método de Bradford (1976), utilizando albumina bovina como padrão e reagente Bio-Rad assay protein (Bio-Rad Lab., Hercules, CA, USA).

A absorbância foi lida em 620 nm, no fotômetro Multiskan EX (Thermo Scientific, Waltham, MA, USA). 


\subsection{Análise Proteômica}

\subsubsection{1-DE em gel de poliacrilamida na presença de SDS (SDS-PAGE)}

Após dosagem das proteínas, as proteínas dos extratos das glândulas salivares $(100 \mu \mathrm{g}$ de proteína por amostra) foram desnaturadas em tampão de amostra em condições redutoras, completamente dissociadas em banho-maria fervente durante 5 minutos e submetidas à SDSPAGE em gel $15 \%$, segundo método descrito por Laemmli (1970), utilizando o aparelho V16-2 Vertical Gel Electrophoresis Apparatus (GIBCO BRL, Rockville, MD, USA).

As proteínas foram coradas com Coomassie Blue R 0,1 \% (Bio Rad Lab) e posteriormente, os géis foram escaneados e as imagens digitalizadas foram analisadas utilizando o software Quantity One (Bio-Rad Lab).

\subsubsection{2-DE em gel de poliacrilamida na presença de SDS (SDP-PAGE)}

\subsubsection{Reidratação das Fitas e Focalização isoelétrica (primeira dimensão)}

As amostras (300 $\mu \mathrm{g}$ de proteínas por amostra) foram precipitadas com acetona, na proporção de 1:3, sendo 1 volume de amostra para 3 volumes de acetona por 3 horas a $-20^{\circ} \mathrm{C}$, depois centrifugadas por 10 minutos a $14.000 \mathrm{~g}$ em temperatura ambiente (JIANG; HE; FOUNTOULAKIS, 2004). Os pellets resultantes foram solubilizados em $250 \mu \mathrm{L}$ de solução de reidratação (DeStreak, GE Healthcare, Uppsala, Sweden) contendo IPG Buffer pH 3-10 $0,5 \%$ (GE Healthcare) e aplicadas na bandeja de reidratação (IPG Box, GE Healthcare). As fitas de $13 \mathrm{~cm}$, pH 3-10 foram posicionadas sobre as amostras para reidratação overnight. Após a reidratação, as fitas foram submetidas à focalização isoelétrica a $20{ }^{\circ} \mathrm{C}$ que foi realizada no sistema Ettan IPGphor II (GE Healthcare) conforme descrito pelo fabricante.Foi utilizado o programa de 5 fases: sendo a primeira etapa a $100 \mathrm{~V}$ durante 2 horas para remoção de sais e impurezas e depois, foi seguido o protocolo recomendado pelo fabricante, até serem acumulados $15.703 \mathrm{Vh}$, com duração total de aproximadamente 7 horas (Tabela 1). 
Tabela 1 - Protocolo de focalização isoelétrica utilizado para fitas de $13 \mathrm{~cm}, \mathrm{pH} 3-10$.

\begin{tabular}{|c|c|c|}
\hline Etapa & Voltagem $(\mathbf{V})$ & Volt-hora $(\mathbf{k V h})$ \\
\hline Primeira fase & 100 & 2 horas \\
\hline Segunda fase & 500 & $500 \mathrm{Vh}$ \\
\hline Terceira fase - Gradiente & 1000 & $800 \mathrm{Vh}$ \\
\hline Quarta fase - Gradiente & 8000 & $11.300 \mathrm{Vh}$ \\
\hline Quinta fase & 8000 & $2.900 \mathrm{Vh}$ \\
\hline
\end{tabular}

\subsubsection{Equilíbrio das fitas}

Após a focalização isoelétrica, as fitas foram tratadas com soluções de equilíbrio ' $A$ ' redutora durante 15 minutos e 'B' alquilante durante mais 15 minutos, ambas etapas sob agitação constante e em temperatura ambiente.

\subsubsection{Gel de poliacrilamida na presença de SDS (SDS-PAGE) (segunda dimensão)}

Após equilíbrio das fitas, estas foram posicionadas sobre o gel de poliacrilamida $12,5 \%$ e cobertas com agarose $0,5 \%$ diluída em tampão de corrida, tendo sido utilizado o padrão de peso molecular Kaleidoscope Prestained Standards (Bio-Rad Lab).

A eletroforese foi realizada de acordo com o método descrito por Laemmli (1970), utilizando o sistema vertical Ettan DALTsix (GE Healthcare). As proteínas foram coradas com Coomassie Blue $\mathrm{G}$, por 3 dias, posteriormente os géis foram descorados com água destilada, em seguida mantidos em solução de preservação, posteriormente os géis foram escaneados, as imagens foram digitalizadas e analisadas através do software ImageMaster-2D Platinum versão 7.0 (GE Healthcare). Os spots foram automaticamente detectados e quando necessário, foram editados manualmente para remover os precipitados do corante. Os spots exclusivos e mais densos de cada grupo experimental de glândulas submandibulares e de parótidas e que apresentavam $p \leq 0,05$ foram considerados para análise, e posteriormente foram selecionados alguns spots que estavam presentes em todos os 3 grupos experimentais dos extratos de glândulas submandibulares e que apresentavam densidades maiores que 2 vezes em pelo menos um dos grupos experimentais, e ainda foram selecionados spots que 
estavam presentes somente no grupo controle e no grupo dos animais tratados com reserpina, fenilefrina e isoprenalina dos extratos de glândulas submandibulares.

\subsubsection{Digestão das proteínas em gel}

Os spots selecionados foram excisados dos géis utilizando bisturi, em seguida foram cortados em pedaços com cerca de $1 \mathrm{~mm}^{3}$ e colocados em microtubos de 0,5 mL siliconizados (Original Eppendorf protein LoBind Tube 0,5 mL, Eppendorf AG, Hamburg, Germany). Foram adicionados $200 \mu \mathrm{L}$ de solução descorante em cada microtubo com trocas subsequentes dessa solução. Esse processo foi repetido durante o tempo necessário até que as amostras estivessem totalmente descoradas. Após essa etapa, a solução descorante foi removida e descartada. Posteriormente, foram adicionados $200 \mu \mathrm{L}$ de acetonitrila $100 \%$ por 5 minutos para desidratação das amostras. Esse procedimento foi repetido até que os pedaços de gel ficassem com aspecto branco opaco. Em seguida o solvente foi removido e as amostras foram secas completamente em um concentrador Speed Vac (Thermo Scientific) por aproximadamente 20 minutos.

Os géis foram em seguida submetidos à digestão enzimática com tripsina. Para tanto, os géis foram reidratados com $15 \mu \mathrm{L}$ de solução de tripsina em gelo e deixados por 45 minutos em banho de gelo para que essa solução pudesse ser absorvida pelos géis. Após esse período, o excesso de tripsina foi removido e descartado. Foram adicionados $20 \mu \mathrm{L}$ de bicarbonato de amônio 40 mM pH 8,0 em cada microtubo, seguido para uma incubação por um período de 16-24 horas, a $37{ }^{\circ} \mathrm{C}$, seguido por uma incubação de 45 minutos a $56{ }^{\circ} \mathrm{C}$.

Após a digestão, cada hidrolisado foi submetido à sonicação em banho de ultrassom por 10 minutos, seguido por um ciclo de vortex por 20 segundos, e então, foram transferidos para novos tubos de $0,5 \mathrm{~mL}$.

Em seguida, a extração dos peptídeos foi feita em 2 ciclos dos seguintes procedimentos: foram adicionados às amostras $30 \mu \mathrm{L}$ de solução de acetonitrila $50 \%$ e ácido fórmico (v/v), seguido por um vortex por 20 segundos, 15 minutos em repouso à temperatura ambiente, posterior sonicação por 2 minutos, 20 segundos de vortex e transferência para os tubos de 0,5 $\mathrm{mL}$ descritos anteriormente. $\mathrm{O}$ volume final dos extratos agrupados foi concentrado em um concentrador Speed Vac (Thermo Scientific) até a secagem total e depois foi armazenado a $-20{ }^{\circ} \mathrm{C}$. 


\subsubsection{Identificação das proteínas por nanocromatografia acoplada ao espectrômetro de massas de alta resolução nanoeletrospray (nESI-LTQ/Orbitrap)}

Para cada fração de $1 \mu \mathrm{L}$ da amostra tripsínica dessalinizada foram adicionados $9 \mu \mathrm{L}$ da solução de ácido fórmico $1 \%$ (v/v). A partir da solução resultante, $4 \mu \mathrm{L}$ foram inicialmente aplicados na coluna de $2 \mathrm{~cm}$ de comprimento (100 $\mu \mathrm{m}$ diâmetro interno) empacotada com a matriz 200 A Magic C18 AQ de $5 \mu \mathrm{m}$ (Michrom Bioresources, Alburn, CA, USA), seguido pela separação em coluna de 10,5 cm de comprimento (75 $\mu$ m diâmetro interno) empacotada com a mesma matriz, diretamente sobre o PicoTip $15 \mu \mathrm{m}$ (New Objective, Cambridge, MA, USA). A cromatografia foi realizada no equipamento EASY-nLC II (Thermo Fisher Scientific, Bremen, Germany). As amostras foram aplicadas na coluna com um fluxo de 2000 $\mathrm{nL} / \mathrm{min}$ e para a separação cromatográfica foi utilizado um fluxo de $200 \mathrm{~nL} / \mathrm{min}$. A fase móvel “A" foi $0,1 \%(\mathrm{v} / \mathrm{v})$ de ácido fórmico em água, enquanto que a fase "B"foi $0,1 \%(\mathrm{v} / \mathrm{v}) \mathrm{de}$ ácido fórmico em acetonitrila e as condições gradientes foram as seguintes: 2 a $40 \%$ de "B" em 32 minutos; até $80 \%$ de "B"em 4 minutos, mantendo esta concentração por mais 2 minutos, antes do reequilíbrio da coluna. Os peptídeos eluídos foram diretamente introduzidos no espectrômetro de massas LTQ XL/Orbitrap (Thermo Fisher Scientific, Bremen, Germany) para análise. A fonte de tensão foi definida para $1,9 \mathrm{kV}$, temperatura capilar de $200{ }^{\circ} \mathrm{C}$ e a voltagem do tubo da lente para $100 \mathrm{~V}$. Os valores alvos para o Ion trap completo e MSn AGC (Automatic Gain control) foram de 30.000 e 10.000 respectivamente, enquanto que o valor alvo do FTMS (Fourier Transform Mass Analysers) AGC foi definido para 500.000. O espectro MS1 foi adquirido no analisador Orbitrap $(\mathrm{m} / \mathrm{z} 300$ a 1.700) com a resolução de 60.000 (para $m / z$ 445.1200). Para cada espectro, os 10 íons mais intensos foram submetidos à fragmentação CID (collision induced dissociation) (sinal mínimo exigido 10.000; largura de isolamento de 2,5; energia de colisão normalizada de 35,0; ativação Q de 0,25 e tempo de ativação de 30 s) seguido pela aquisição no MS2 do analisador linear. A opção de exclusão dinâmica foi ativada e habilitada com os seguintes valores definidos para cada parâmetro (repetição da contagem $=1$; duração da repetição $=30$ segundos; tamanho da lista de exclusão = 500; duração da exclusão = 45 segundos e largura da massa de exclusão = 10 ppm). 


\subsubsection{Análise dos dados}

Todos os dados gerados foram analisados pelo software PEAKS versão 6 build 201320220 (Bioinformatics Solutions Inc, Waterloo, Canada). Primeiramente, os dados brutos foram submetidos ao refinamento, onde se procedeu à correção da massa do precursor e dos processos peak centroiding, charge deconvolution e deisotoping. Para as análises posteriores foram utilizados os limites de tolerância para os valores de massa dos íons precursores de 20 ppm e para os íons fragmentos de 0,6 Da. Além disso, foi considerada a digestão enzimática do tipo semi-triptica e foi aceito no máximo duas clivagens por proteína. Todos os dados foram submetidos inicialmente à busca pela ferramenta De Novo, permitindo-se modificações variáveis em cistina (+57.02 Da - carbamido metilação) e metionina, histidina e triptofano (+15,99 Da - oxidação), sendo aceito o máximo de duas modificações por peptídeo. Em seguida, foi realizada a busca mediante a ferramenta de pesquisa PEAKS DB, estabelecendo a massa do precursor como monoisotópica e permitindo uma modificação variável em cisteína (+57.02 Da), sendo aceitáveis no máximo duas modificações por peptídeo. Todas as buscas foram realizadas utilizando o banco de dados público NCBI não redundante (Proteopeptidome_NCBInr_25032013) nos bancos de dados Mus musculus. A gama de detecção falsa (FDR - False Discovery Rate) foi estimada através do uso da ferramenta decoy. Finalmente, os dados de todas as buscas foram consolidados e somente os resultados no qual o FDR estimado foi menor ou igual a $1 \%$ foram aceitos como identificações confiáveis. Todas as informações das proteínas identificadas estão de acordo com dados coletados no UniProt (http://uniprot.org). 
4 RESULTADOS 
Iniciamos nossos estudos padronizando as doses de reserpina, de fenilefrina e isoprenalina (agonistas de adrenoceptores alfa e beta). As doses utilizadas foram baseadas em dados da literatura. Assim, o protocolo mais adequado às nossas condições experimentais foi baseado no trabalho de Watson et al. (1984), no qual os animais foram tratados com injeções diárias de reserpina (tratamento crônico) na dose de $0,5 \mathrm{mg} / \mathrm{kg}$.

\subsection{Importância do Sistema Nervoso Simpático na composição proteica das glândulas salivares de camundongos}

\subsubsection{Glândulas Submandibulares}

\subsubsection{Análise dos perfis proteicos após 1-DE}

Através da análise dos perfis proteicos dos géis 1-DE dos extratos das glândulas submandibulares dos grupos controle, tratado com reserpina e tratado com RES + FEN + ISO foi possível observar que bandas de aproximadamente 96, 44, 39, 37 e 35 kDa (Figura 5, indicadas pelas setas) tiveram uma redução de densidade após o tratamento com reserpina quando comparado com o perfil proteico do grupo controle. Observou-se ainda que em animais previamente tratados com reserpina por 6 dias consecutivos, a administração de uma única dose fenilefrina e isoprenalina foi capaz de restaurar parcialmente o efeito causado pela reserpina, onde o perfil proteico mostrou-se similar ao observado no grupo controle (Figura 5). Essas alterações dos perfis proteicos também foram observadas em glândulas de veneno de Bothrops jararaca (LUNAet al., 2009). 
Figura 5 - Efeitos da reserpina e da estimulação dos adrenoceptores alfa e beta na composição proteica das glândulas submandibulares em animais previamente reserpinizados.

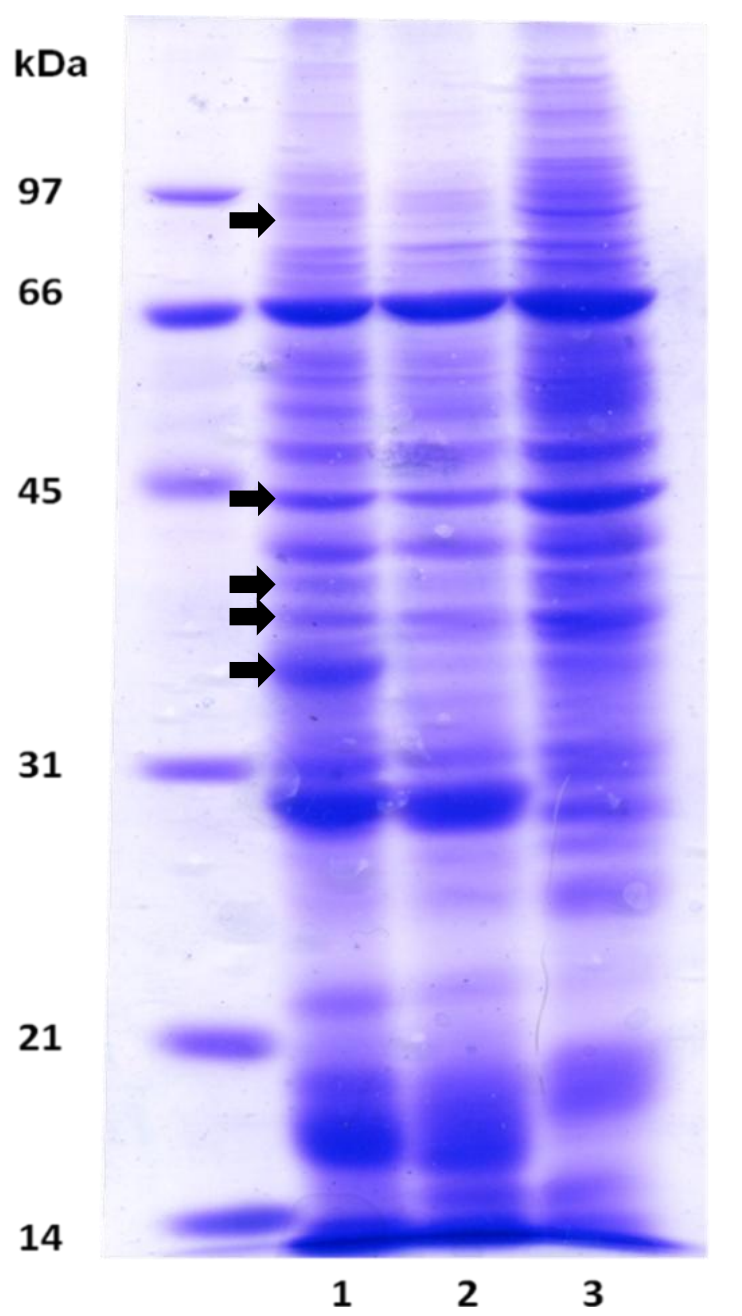

As proteínas $(100 \mu \mathrm{g})$ foram separadas em gel 1-DE $15 \%$. (1 - grupo controle; 2 - grupo dos animais tratados com reserpina $0,5 \mathrm{mg} / \mathrm{kg}$ por 6 dias consecutivos; 3 - grupo dos animais tratados com reserpina $0,5 \mathrm{mg} / \mathrm{kg}$ por 6 dias consecutivos e com fenilefrina, $20 \mathrm{mg} / \mathrm{kg}$ e isoprenalina, $20 \mathrm{mg} / \mathrm{kg}$ no último dia de tratamento). Setas indicam bandas de 96, 44, 39, 37 e $35 \mathrm{kDa}$ que tiveram redução na densidade proteica após tratamento com reserpina e que aumentaram após administração de fenilefrina e isoprenalina. $\mathrm{N}=3$.

\subsubsection{Análise dos perfis proteicos após 2-DE}

Para a identificação das proteínas que tiveram sua expressão alterada pelo tratamento crônico com reserpina ou com reserpina e agonistas de adrenoceptores alfa e beta, passamos para a realização da eletroforese bidimensional, utilizando fitas de $13 \mathrm{~cm}$, com faixa de $\mathrm{pH}$ de 
3 a 10, uma vez que os extratos de glândulas submandibulares de camundongos possuem proteínas de alto e baixo peso molecular distribuídas em uma ampla faixa de $\mathrm{pH}$.

A análise dos perfis proteicos dos extratos das glândulas submandibulares mostrou a presença de vários spots em cada grupo experimental, sendo que 36 spots foram comuns aos 3 grupos experimentais (Figura 6). Além disso, foram detectados 32 spots exclusivos do grupo controle, 30 do grupo dos animais reserpinizados e 102 no grupo de animais tratados com reserpina e com agonistas de adrenoceptores alfa e beta. Foram detectados ainda, 37 spots comuns entre o grupo controle (glândula ativa) e o grupo dos animais tratados com reserpina, fenilefrina e isoprenalina, 20 spots entre o grupo controle e o grupo dos reserpinizados e 14 spots comuns entre o grupo dos animais tratados com reserpina e o grupo dos tratados com reserpina e com os agonistas de adrenoceptores (Figura 6).

Figura 6 - Diagrama de Venn representando o número de spots exclusivos, presentes nos extratos de glândulas submandibulares e em comum entre os grupos experimentais.

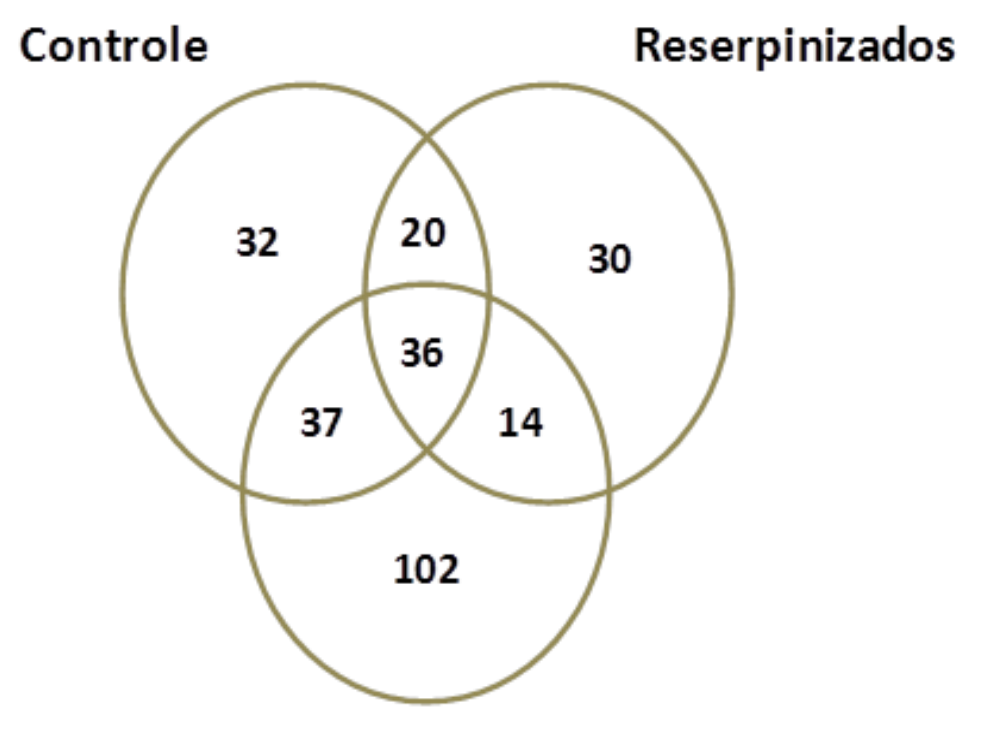

Tratados RES + FEN + ISO

$\mathrm{N}=3$, géis 2-DE realizados em triplicata para cada amostra. RES - reserpina; FEN - fenilefrina; ISOisoprenalina. 


\subsubsection{Identificação das proteínas reguladas pela inervação simpática em glândulas} submandibulares de camundongos

Para a identificação das proteínas, os spots de interesse foram recortados dos géis, descorados e submetidos à digestão tríptica e os peptídeos resultantes foram submetidos à análise por nanocromatografia acoplada ao espectrômetro de massas de alta resolução nano eletrospray (nanoESI-LTQ/Orbitrap XL) no Laboratório de Toxicologia do Instituto Oswaldo Cruz - FIOCRUZ.

Inicialmente foram feitas as identificações dos spots exclusivos de cada grupo experimental.

Para tanto, foram selecionados os spots exclusivos com densidade maior ou igual a 0,03 de cada grupo experimental (18 spots no grupo controle, 22 spots no grupo dos animais reserpinizados e 37 spots no grupo dos animais tratados com reserpina, fenilefrina e isoprenalina) para serem identificados e os géis representativos com os spots selecionados estão representados nas figuras $7 \mathrm{~A}, \mathrm{~B}, \mathrm{C}$. 
Figura 7 - Gel 2-DE de SDS-poliacrilamida de extrato de glândula submandibular de camundongo indicando os spots exclusivos selecionados nos 3 grupos experimentais que foram submetidos à espectrometria de massas.

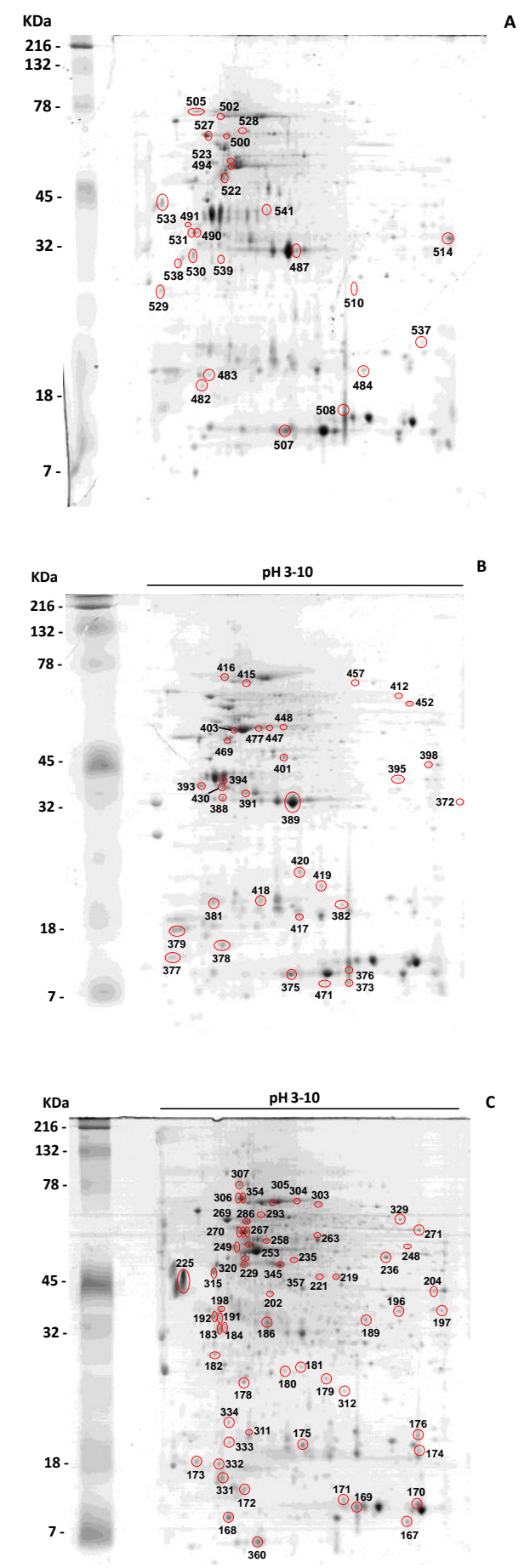

(A) Grupo Controle. (B) Grupo dos animais tratados com reserpina. (C) Grupo dos animais tratados com reserpina e isoprenalina e fenilefrina. Os círculos vermelhos e os números referem-se aos spots exclusivos de cada condição que foram selecionados para serem identificados por espectrometria de massas. $\mathrm{N}=3$, em triplicata. 
A partir da análise dos dados de espectrometria de massas, nós pudemos identificar 361 proteínas no grupo controle, 459 proteínas no grupo dos animais reserpinizados e 546 proteínas no grupo dos animais tratados com reserpina e com os agonistas de adrenoceptores alfa e beta. Todas as informações sobre as proteínas identificadas estão nos Apêndices A, B e $\mathrm{C}$ e foram baseadas em informações coletadas no banco de dados UniProt.

Em uma primeira abordagem as espécies de proteínas identificadas nesse estudo foram classificadas de acordo com suas localizações subcelulares. De acordo com essa análise, foram detectadas proteínas do citoplasma, da mitocôndria, do retículo endoplasmático (RE), da membrana, do núcleo, do peroxissomo, do Golgi, do lisossomo e proteínas secretadas nos 3 grupos experimentais (Figuras 8A, B, C). Ao analisarmos as porcentagens de proteínas identificadas de cada compartimento subcelular em relação ao total identificado por grupo experimental, verificamos que houve diferença na porcentagem de proteínas mitocondriais e do núcleo após o tratamento crônico com reserpina. O número de espécies de proteínas identificadas como mitocondriais aumentou e as espécies de proteínas do núcleo reduziram após tratamento crônico com reserpina e o posterior tratamento com os agonistas de adrenoceptores alfa e beta restaurou esses efeitos, sugerindo que a inervação simpática está regulando a síntese destas proteínas nas glândulas submandibulares de camundongos. 
Figura 8 - Distribuição subcelular das espécies de proteínas exclusivas presentes nos extratos de glândulas submandibulares de camundongos de cada grupo experimental identificadas por espectrometria de massas.
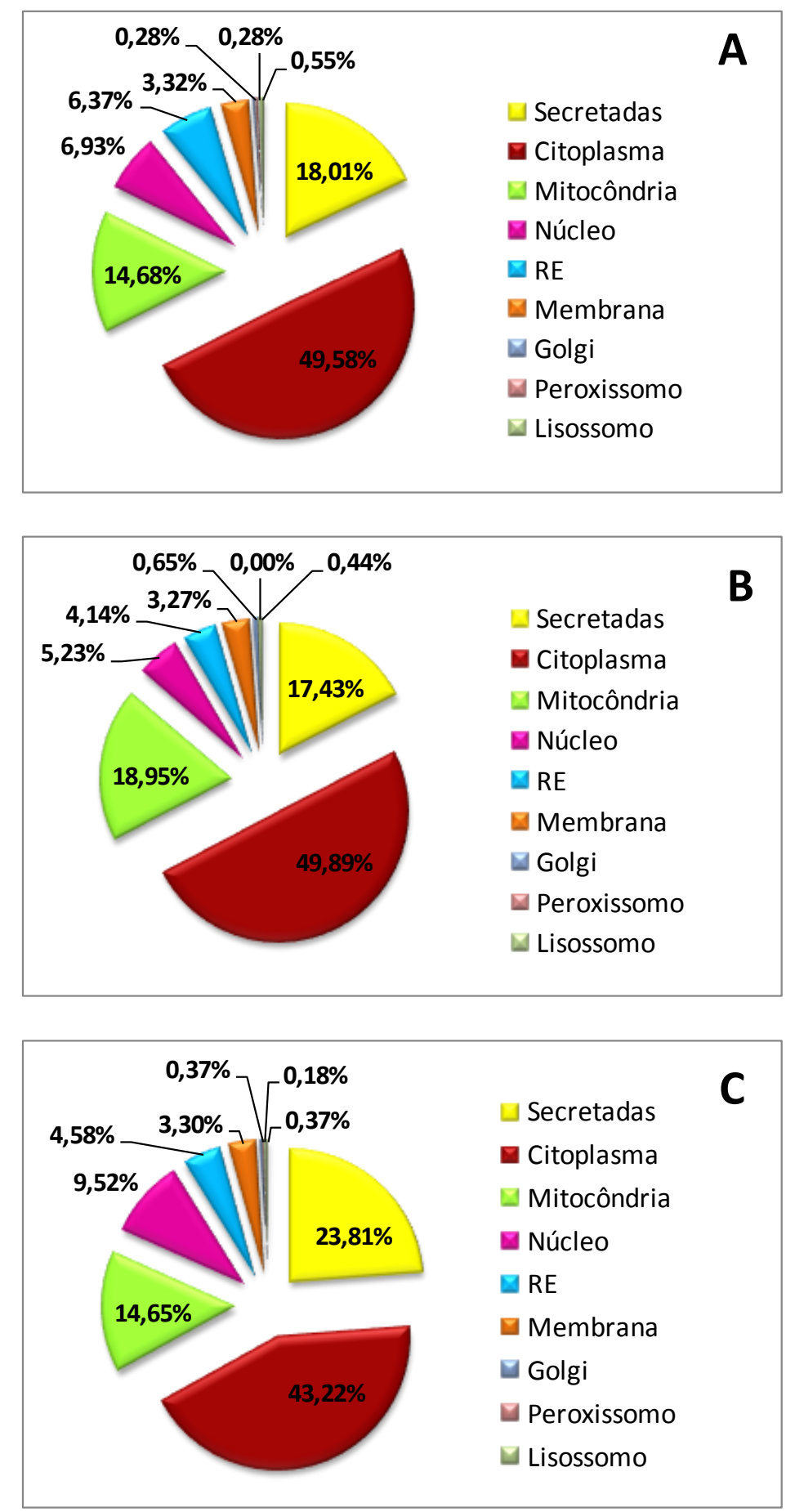

(A) Grupo controle. (B) Grupo dos animais tratados cronicamente com reserpina. (C) Grupo dos animais tratados com reserpina, fenilefrina e isoprenalina. A classificação das proteínas foi obtida no banco de dados Uniprot. 
Foi realizada uma segunda abordagem, classificando essas proteínas de acordo com suas funções celulares (Figuras 9A, B, C).

Comparando as porcentagens de proteínas identificadas de acordo com as suas funções, verificamos que o tratamento crônico com reserpina levou a uma redução do número de espécies de proteínas envolvidas na organização do citoesqueleto e na biossíntese de proteínas, e a um aumento do número de espécies de proteínas envolvidas nos processos biossintéticos e metabólicos. O efeito causado pela reserpina foi restaurado pela posterior administração de fenilefrina e isoprenalina, agonistas de adrenoceptores alfa e beta, respectivamente. Esses resultados sugerem que a inervação simpática regula alguns processos biológicos, os quais são importantes para o funcionamento das glândulas submandibulares de camundongos. 
Figura 9 - Distribuição das espécies de proteínas exclusivas presentes nos extratos de glândulas submandibulares de camundongos de cada grupo experimental identificadas por espectrometria de massas de acordo com suas funções celulares.
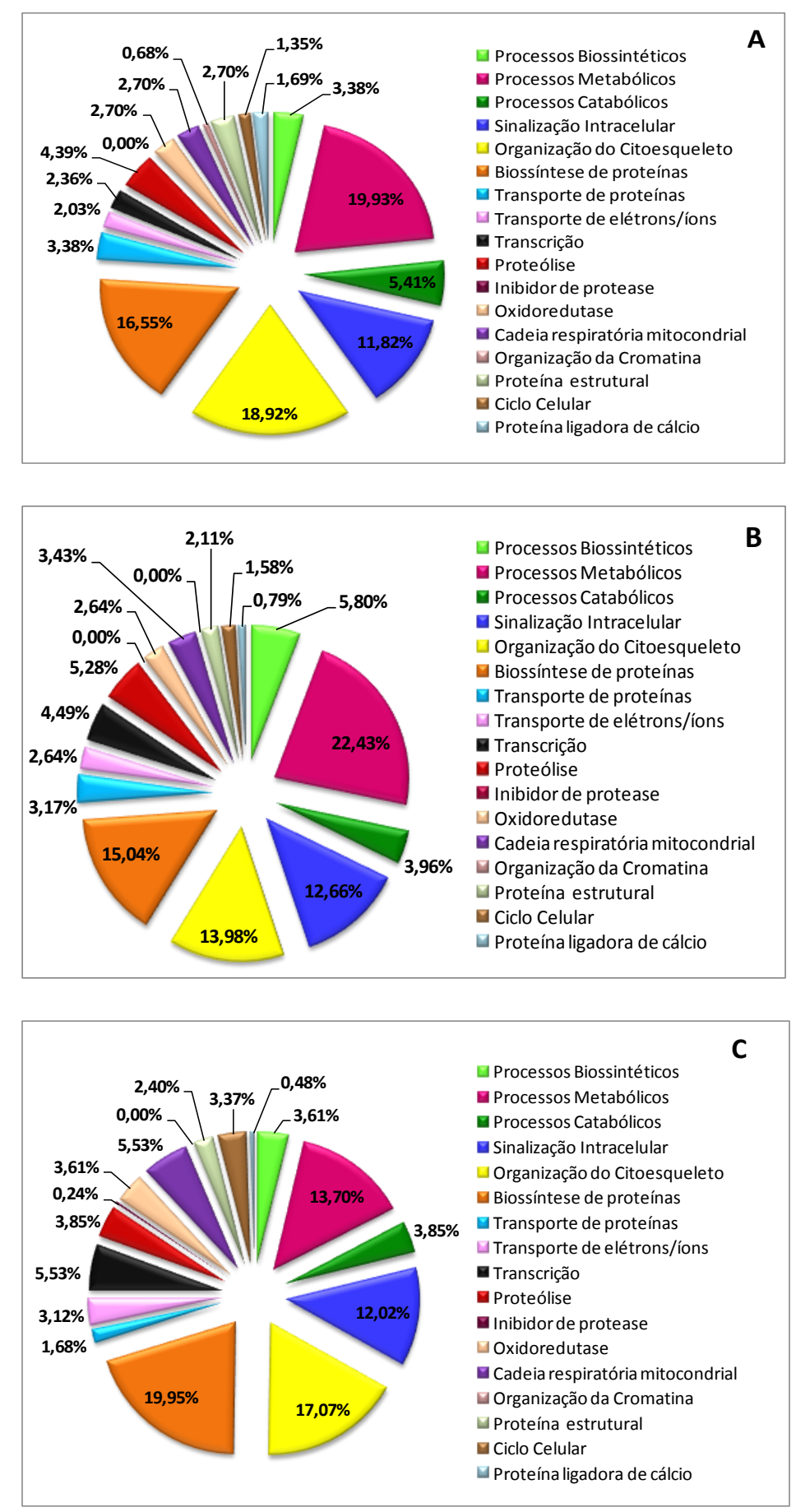

(A) Grupo controle. (B) Grupo dos animais tratados com reserpina. (C) Grupo dos animais tratados com reserpina, fenilefrina e isoprenalina. Classificação das proteínas de acordo com suas funções foi obtida no banco de dados Uniprot. 
Posteriormente, foram selecionados também alguns spots presentes nos extratos de glândulas submandibulares dos 3 grupos experimentais estudados. Dentre os 36 spots comuns aos 3 grupos experimentais, foram selecionados apenas os spots que apresentaram densidades 2 vezes maiores em pelo menos um dos grupos experimentais. Para verificar o papel da inervação simpática nas glândulas submandibulares, foram selecionados somente aqueles spots que tiveram sua densidade reduzida ou aumentada após tratamento crônico com reserpina e esses efeitos revertidos pelo tratamento posterior com os agonistas de adrenoceptores alfa e beta (Tabelas 2, 3). Portanto, foram selecionados 4 spots cujas densidades foram aumentadas e 5 spots cujas densidades foram reduzidas pelo tratamento crônico com reserpina (Figura 10).

Tabela 2 - Densidades dos spots presentes nos 3 grupos experimentais que tiveram as densidades diminuídas após tratamento crônico com reserpina em relação ao grupo controle e restauradas após o tratamento com os agonistas de adrenoceptores.

\begin{tabular}{|c|c|c|c|}
\hline Match ID $\left(\mathbf{n}^{\circ}\right.$ spot $)$ & Controle & Reserpinizados & $\begin{array}{c}\text { Tratados RES } \\
\text { FEN + ISO }\end{array}$ \\
\hline $\mathbf{5 1}$ & 0,67685 & 0,323636 & 0,788507 \\
\hline $\mathbf{6 3}$ & 0,122404 & 0,068276 & 0,922095 \\
\hline $\mathbf{7 9}$ & 0,0993068 & 0,0217151 & 0,182189 \\
\hline $\mathbf{8 5}$ & 0,158235 & 0,0566568 & 0,191424 \\
\hline $\mathbf{1 0 7}$ & 0,649968 & 0,264749 & 1,07729 \\
\hline
\end{tabular}

Dados obtidos de acordo com análise pelo software ImageMaster-2D Platinum versão 7.0 (GE Healthcare, Uppsala, Sweden). RES - reserpina; FEN - fenilefrina; ISO - isoprenalina. 
Tabela 3 - Densidades dos spots presentes nos 3 grupos experimentais que tiveram as densidades aumentadas após tratamento crônico com reserpina em relação ao grupo controle e restauradas após o tratamento com os agonistas de adrenoceptores.

\begin{tabular}{|c|c|c|c|}
\hline Match ID (n & Controle & Reserpinizados & $\begin{array}{c}\text { Tratados RES } \\
\text { FEN + ISO }\end{array}$ \\
\hline $\mathbf{0 4}$ & 0,477753 & 0,8575594 & 0,484242 \\
\hline $\mathbf{3 5}$ & 0,181064 & 0,359741 & 0,149845 \\
\hline $\mathbf{6 6}$ & 0,0766503 & 0,22846 & 0,0126687 \\
\hline $\mathbf{1 1 1}$ & 0,678927 & 1,40948 & 0,224461 \\
\hline
\end{tabular}

Dados obtidos de acordo com análise pelo software ImageMaster-2D Platinum versão 7.0 (GE Healthcare, Uppsala, Sweden). RES - reserpina; FEN - fenilefrina; ISO - isoprenalina.

Dos 4 spots selecionados que tiveram aumento na densidade após o tratamento crônico com reserpina, foi possível identificar 121 proteínas (Apêndice D) e dos 5 spots que tiveram suas densidades reduzidas, foram identificadas 150 proteínas (Apêndice E).

Inicialmente, essas proteínas identificadas foram classificadas de acordo com suas localizações subcelulares, baseadas em informações coletadas no UniProt.

Das proteínas que tiveram suas sínteses reduzidas pelo tratamento crônico com reserpina e esses efeitos revertidos pela posterior administração dos agonistas de adrenoceptores alfa e beta, podemos ressaltar as proteínas secretadas, citoplasmáticas e mitocondriais e das proteínas que tiveram sua síntese aumentada, destacam-se proteínas secretadas, citoplasmáticas, mitocondriais e do retículo endoplasmático (Figuras 11A, B). 
Figura 10 - Gel 2-DE de SDS-poliacrilamida de extratos de glândulas submandibulares de camundongos indicando os spots comuns aos 3 grupos experimentais que foram submetidos à espectrometria de massas.

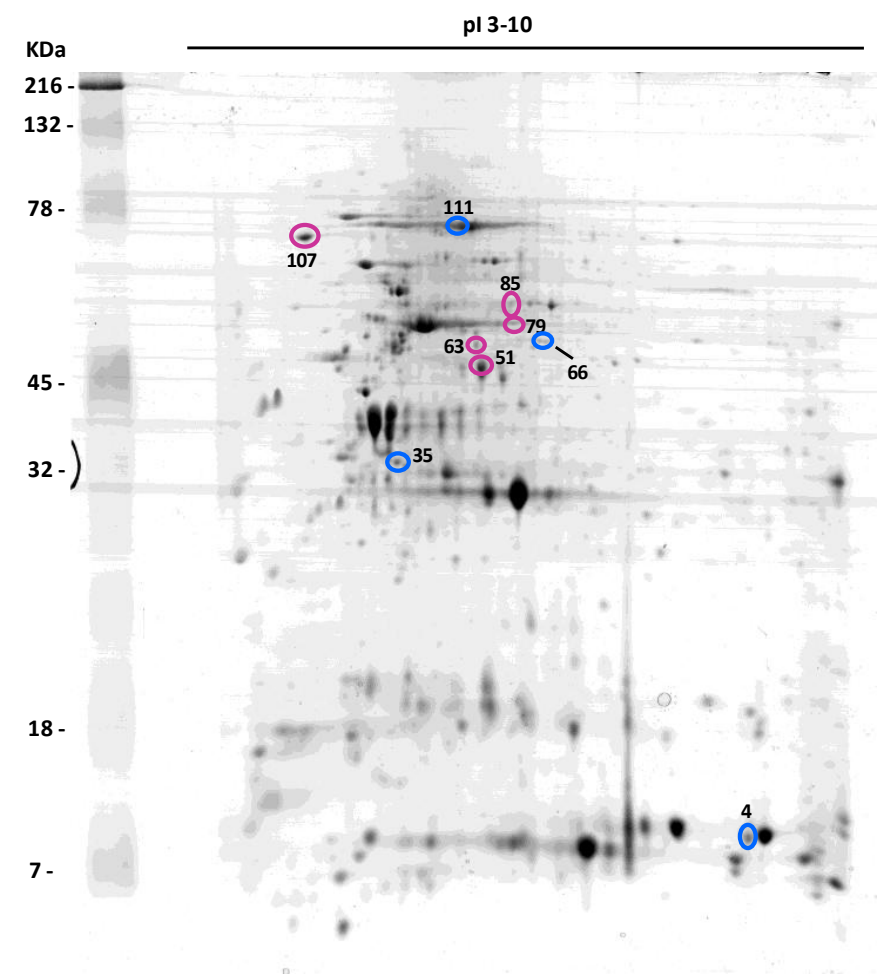

Perfil proteico representativo do extrato de glândulas submandibulares após bloqueio da atividade simpática por reserpina e posterior administração dos agonistas de adrenoceptores. Círculos indicam os spots identificados por espectrometria de massas que estão presentes nos 3 grupos experimentais. Círculos azuis indicam os spots que tiveram aumento de densidades e círculos rosa indicam os spots que tiveram redução de densidade após tratamento crônico com reserpina. $\mathrm{N}=3$, em triplicata.

Analisando posteriormente a distribuição dessas proteínas identificadas de acordo com suas funções, verificamos que a maioria das espécies de proteínas identificadas e que tiveram suas sínteses aumentadas quando tratadas cronicamente com reserpina, estão envolvidas em processos metabólicos, organização do citoesqueleto e biossíntese de proteínas. As proteínas que tiveram suas sínteses reduzidas após tratamento crônico com reserpina estão envolvidas em processos biossintéticos, metabólicos, sinalização intracelular, organização do citoesqueleto, biossíntese de proteínas e proteólise (Figuras 12A, B). Esses resultados sugerem que a inervação simpática tem um papel relevante na homeostase celular, bem como na síntese e secreção de proteínas. 
Figura 11 - Distribuição subcelular das espécies de proteínas identificadas presentes em extratos de glândulas submandibulares de camundongos dos 3 grupos experimentais.
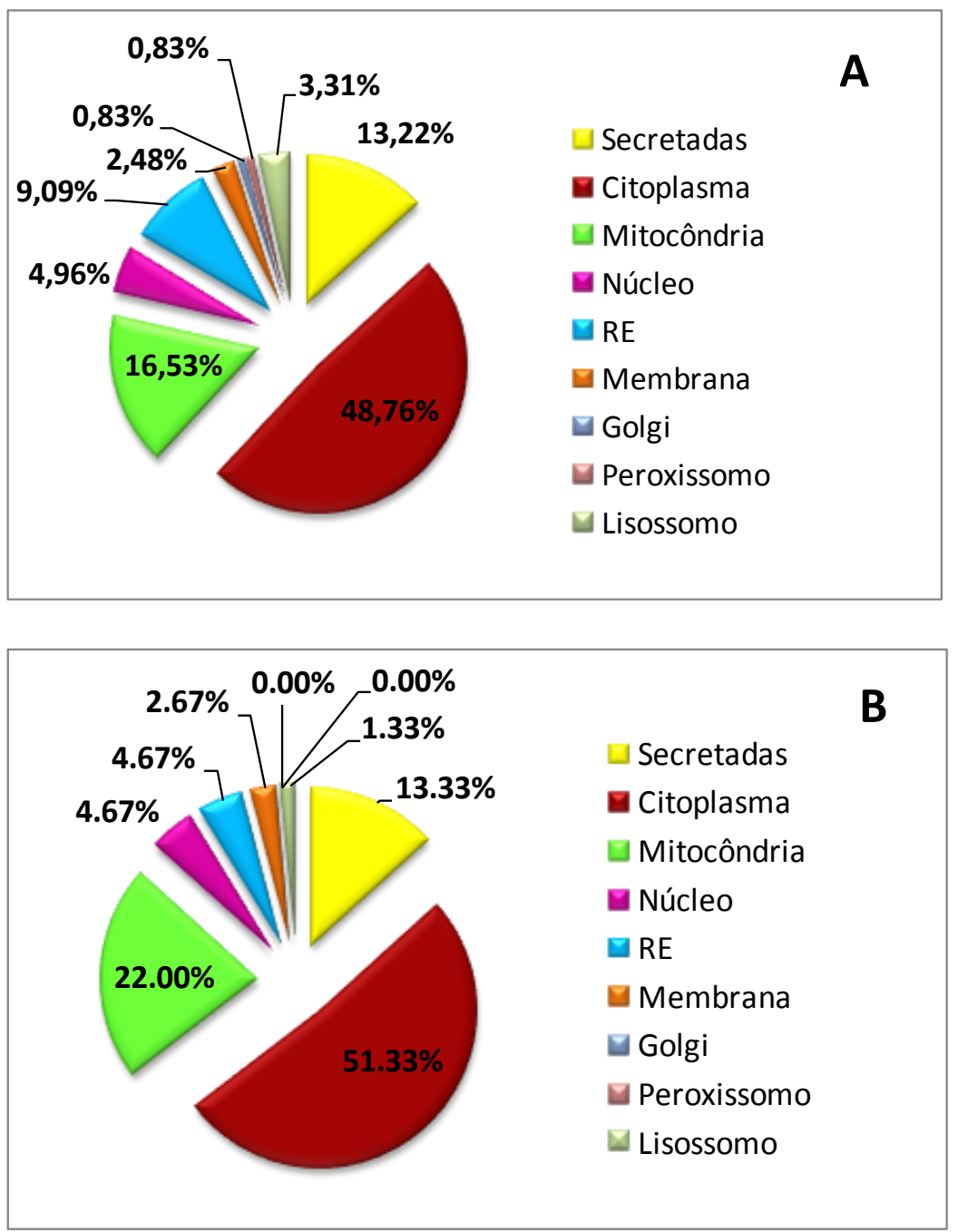

(A) Espécies de proteínas que tiveram aumento na densidade após administração de reserpina. (B) Espécies de proteínas que tiveram redução na densidade após administração da reserpina. Classificação das proteínas de acordo com sua função foi obtida no banco de dados Uniprot. 
Figura 12 - Distribuição das espécies de proteínas identificadas presentes nos extratos de glândulas submandibulares de camundongos dos 3 grupos experimentais de acordo com suas categorias funcionais.
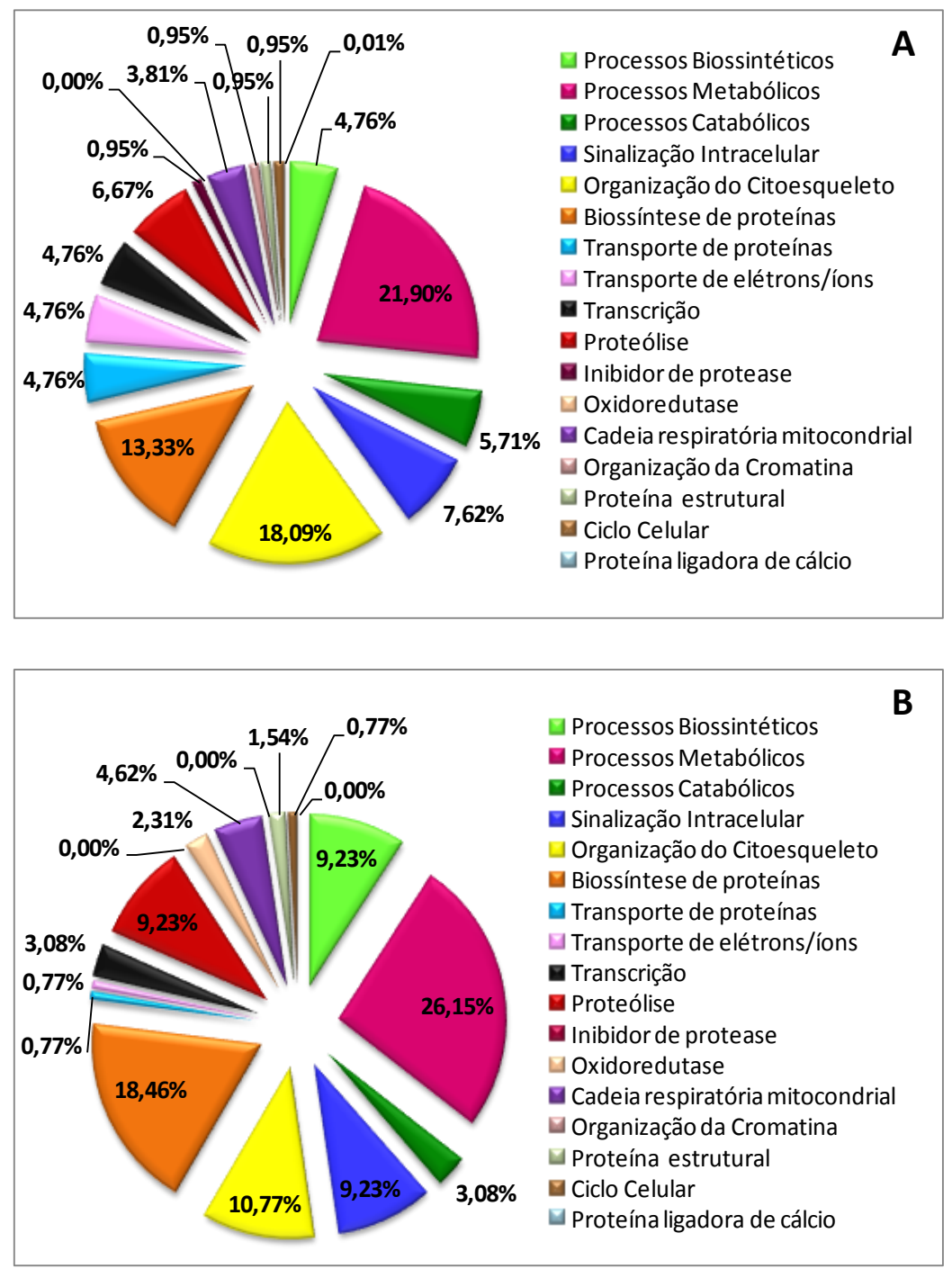

(A) Espécies de proteínas identificadas que tiveram um aumento nas suas densidades após tratamento com reserpina. (B) Espécies de proteínas identificadas que tiveram uma redução nas suas densidades após tratamento com reserpina com relação ao grupo controle e ao grupo dos animais tratados com agonistas de adrenoceptores. Classificação das proteínas de acordo com sua função foi obtida no banco de dados Uniprot. 
Considerando que o grupo controle corresponde à glândula no seu estado ativado e que a inervação simpática pode estar participando para manter a glândula neste estado de ativação, como visto anteriormente em glândulas de veneno da serpente Bothrops jararaca (LUNA et al., 2009), realizamos outra análise onde foram considerados os spots comuns entre o grupo controle e o grupo dos animais tratados com reserpina e com fenilefrina e isoprenalina, com densidade maior ou igual a 0,02 (Figura 13).

Figura 13 - Gel 2-DE de SDS-poliacrilamida de extrato de glândula submandibular de camundongo indicando os spots comuns entre o grupo controle e o grupo dos animais tratados com reserpina, fenilefrina e isoprenalina que foram submetidos à espectrometria de massas.

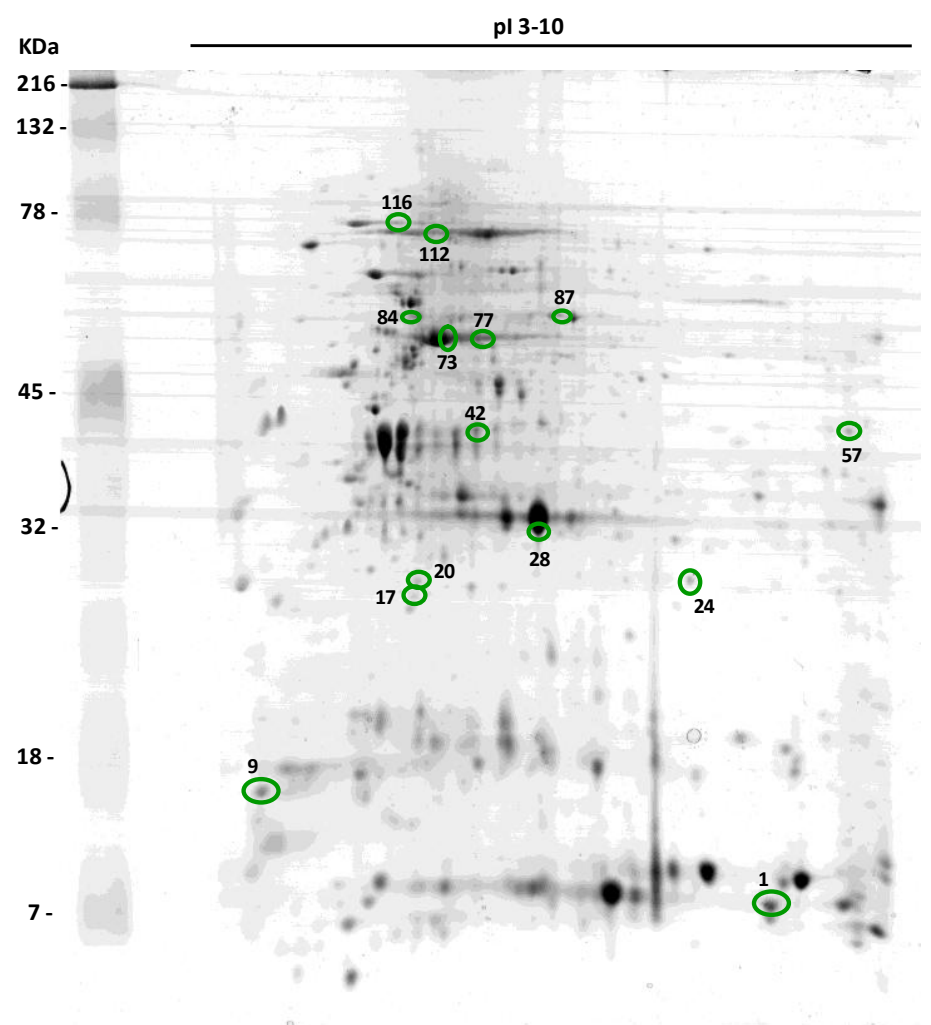

Perfil proteico representativo do extrato de glândulas submandibulares após bloqueio da atividade simpática por reserpina e posterior administração dos agonistas de adrenoceptores. Círculos verdes indicam os spots comuns ao grupo controle (glândula ativa) e ao grupo dos animais tratados com reserpina, fenilefrina e isoprenalina e que foram identificados por espectrometria de massas. $\mathrm{N}=3$, em triplicata. 
Dos 14 spots selecionados foram identificadas 408 proteínas (Apêndice F), as quais foram classificadas de acordo com suas localizações subcelulares (Figura 14). De acordo com essa classificação, foram detectadas principalmente proteínas secretadas, do citoplasma e da mitocôndria.

Posteriormente, essas proteínas identificadas foram distribuídas de acordo com suas categorias funcionais (Figura 15). Analisando a distribuição dessas proteínas identificadas de acordo com suas funções, vimos que a maioria das espécies de proteínas identificadas estão envolvidas em processos metabólicos, sinalização intracelular, organização do citoesqueleto, biossíntese de proteínas e proteólise. Esses resultados corroboram com as análises dos spots comuns aos 3 grupos experimentais. Portanto, esses dados sugerem que a inervação simpática tem um papel relevante na homeostase celular, bem como na síntese e secreção de proteínas.

Figura 14 - Distribuição subcelular das espécies de proteínas identificadas presentes nos extratos de glândulas submandibulares de camundongos do grupo controle e do grupo dos animais tratados com RES + FEN + ISO.

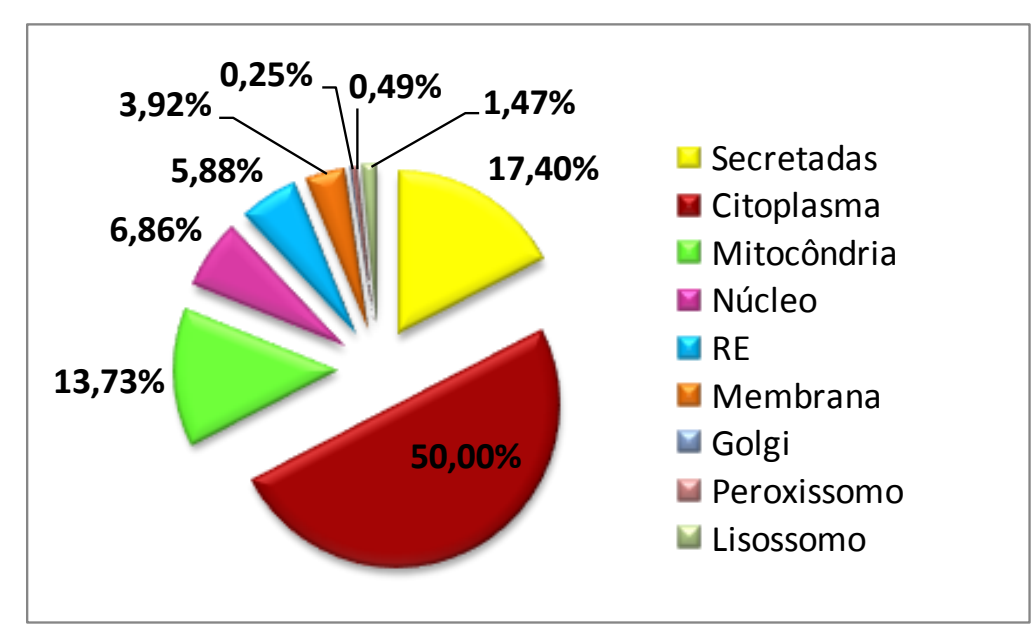

Espécies de proteínas que são comuns ao grupo controle e ao grupo dos animais tratados com reserpina (RES), fenilefrina (FEN) e isoprenalina (ISO). Classificação das proteínas de acordo com sua localização subcelular foi obtida no banco de dados Uniprot. 
Figura 15 - Distribuição das espécies de proteínas identificadas presentes extratos glândulas submandibulares de camundongos do grupo controle e do grupo dos animais tratados com RES + FEN + ISO de acordo com suas categorias funcionais.

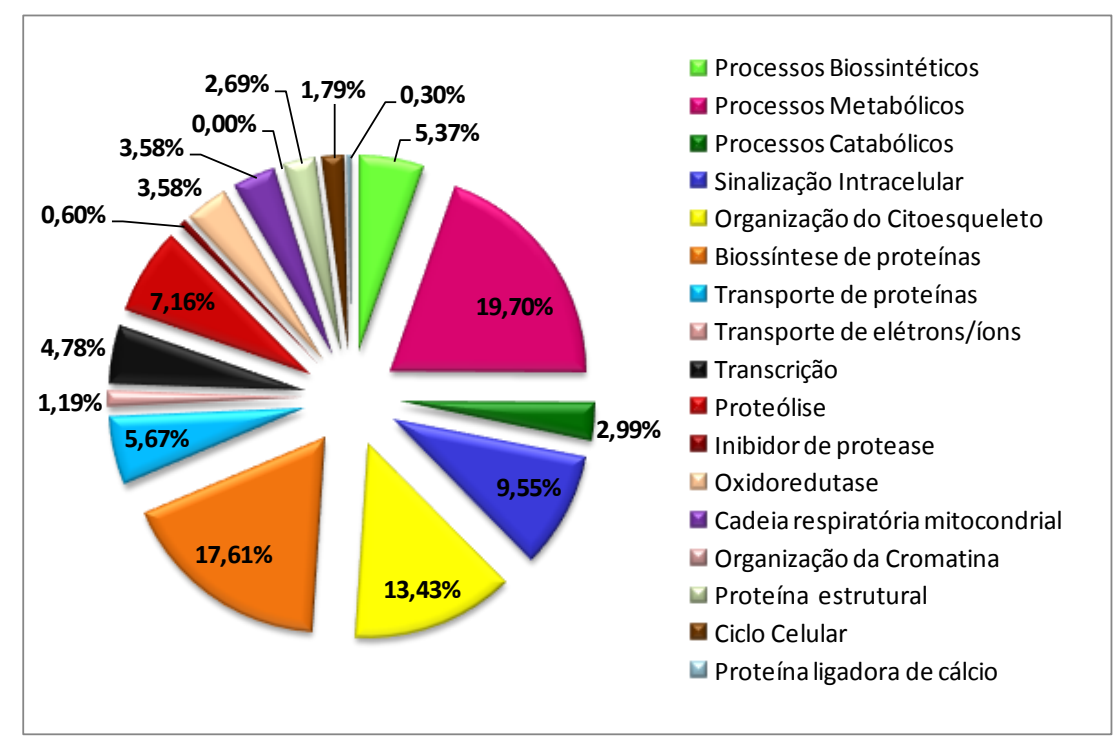

Classificação das espécies de proteínas comuns ao grupo controle e ao grupo dos tratados com reserpina (RES), fenilefrina (FEN) e isoprenalina (ISO) de acordo com sua localização subcelular obtida no banco de dados Uniprot.

\subsubsection{Glândulas Parótidas}

\subsubsection{Análise dos perfis proteicos após 1-DE}

Com relação à análise dos perfis proteicos dos extratos das glândulas parótidas após 1DE,verificamos que após a administração crônica de reserpina houve alterações nas densidades de algumas bandas. As bandas de aproximadamente 96, 51, 33, 24 e 20 KDativeram um aumento de densidade após o tratamento com reserpina (indicado pelas setas) quando comparadas às bandas do extrato do grupo controle (Figura 16).

De acordo com esses dados, observamos também que em animais previamente tratados com reserpina, a administração de fenilefrina e isoprenalina (agonistas dos adrenoceptores alfa e beta, respectivamente) foram capazes de restaurar parcialmente o efeito da reserpina, onde o perfil proteico mostrou-se similar ao do grupo controle (Figura 16). Essas alterações dos perfis proteicos também foram observadas em glândulas submandibulares já mostradaspreviamente e também em glândulas de veneno de Bothrops jararaca(LUNAet al., 
2009), no entanto, nenhuma proteína teve sua densidade reduzida como na glândula submandibular de camundongos e na glândula de veneno de serpentes, sugerindo que na glândula parótida de camundongos, a noradrenalina regula diferentemente a síntese de proteínas.

Figura 16 - Efeitos da reserpina e da estimulação dos adrenoceptores alfa e beta em animais previamente reserpinizados na composição proteica das glândulas parótidas de camundongos.

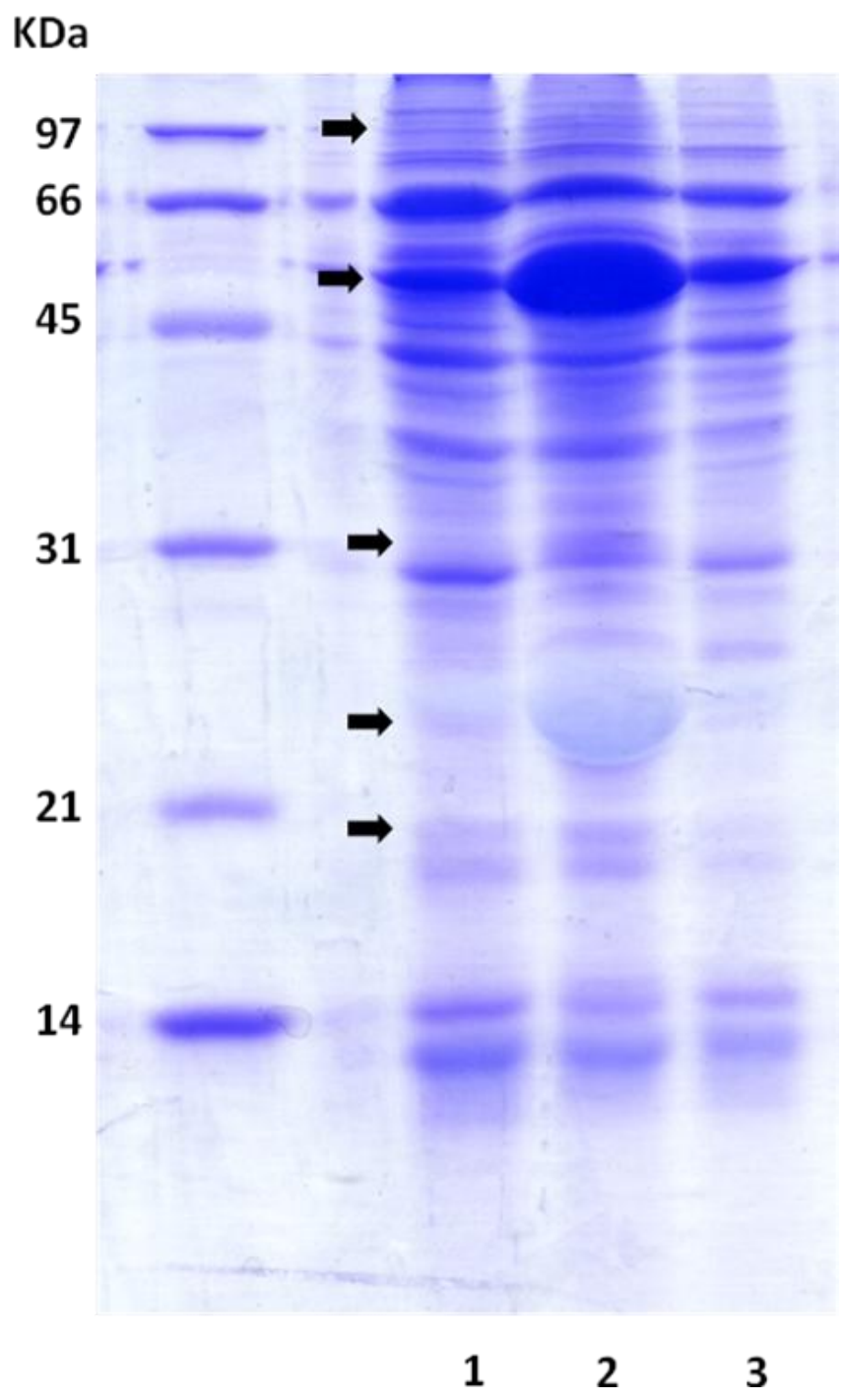

As proteínas $(100 \mu \mathrm{g})$ foram separadas em gel SDS-PAGE $15 \%$. (1- grupo controle; 2 - grupo dos animais tratados com reserpina $0,5 \mathrm{mg} / \mathrm{kg}$ por 6 dias consecutivos; 3 - grupo dos animais tratados com reserpina 0,5 $\mathrm{mg} / \mathrm{kg}$ por 6 dias consecutivos e com fenilefrina, $20 \mathrm{mg} / \mathrm{kg}$ e isoprenalina, $20 \mathrm{mg} / \mathrm{kg}$ no último dia de tratamento). Setas indicam bandas que tiveram aumento na densidade proteica após tratamento com reserpina e que diminuíram após administração de fenilefrina e isoprenalina. $\mathrm{N}=3$. 


\subsubsection{Análise dos perfis proteicos após 2-DE}

Para a identificação das proteínas que tiveram sua expressão alterada pelo tratamento com reserpina ou com reserpina e agonistas dos adrenoceptores alfa e beta, passamos para a realização da 2-DE, utilizando fitas de $13 \mathrm{~cm}$, com faixa de $\mathrm{pH}$ de 3 a 10, uma vez que os extratos de glândulas parótidas de camundongos também possuem proteínas de alto e baixo peso molecular distribuídas em uma ampla faixa de $\mathrm{pH}$.

A análise dos perfis proteicos dos extratos das glândulas parótidas dos 3 grupos experimentais mostrou que 26 spots foram comuns aos 3 grupos experimentais (Figura 17). Além disso, foram detectados 91 spots exclusivos do grupo controle, 131 no grupo dos animais reserpinizados e 119 no grupo de animais reserpinizados e tratados com agonistas de adrenoceptores. Foram detectados ainda, 33 spots comuns entre o grupo controle (glândula ativa) e o grupo dos animais reserpinizados e tratados com fenilefrina e isoprenalina, 37 spots entre o grupo controle e o grupo dos reserpinizados e 30 spots comuns entre o grupo dos animais tratados com reserpina e o grupo dos tratados com reserpina e com os agonistas de adrenoceptores alfa e beta (Figura 17).

Figura 17 - Diagrama de Venn representando o número de spots exclusivos presentes nos extratos de glândulas parótidas e em comum entre os 3 grupos experimentais.

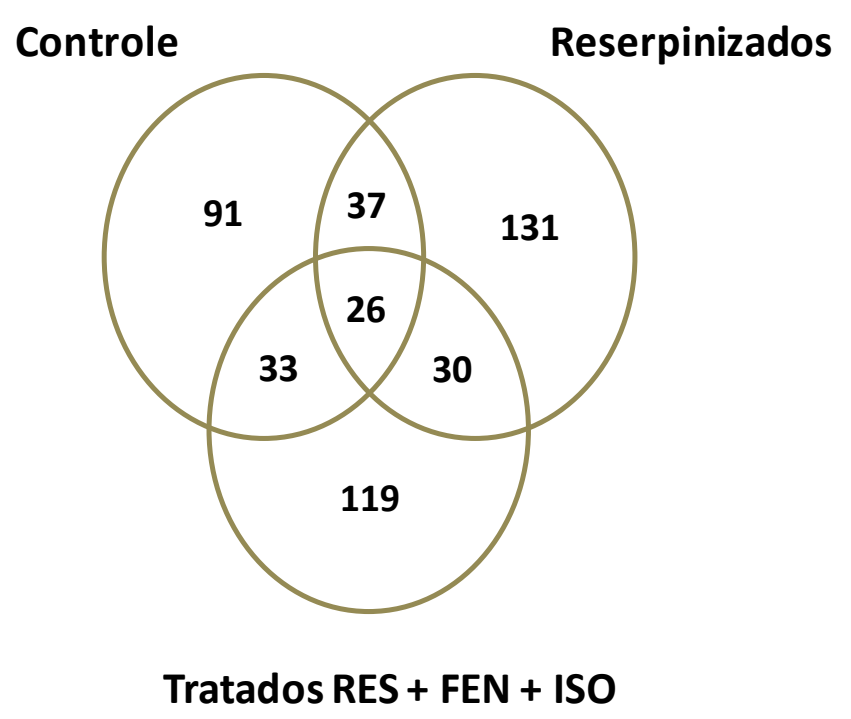

Géis 2-DE realizados em duplicata para cada grupo experimental. RES = reserpina; FEN = fenilefrina; $\mathrm{ISO}=$ isoprenalina, $\mathrm{N}=5$. 
4.1.2.3 Identificação das proteínas reguladas pela inervação simpática em glândulas parótidas de camundongos

Uma vez analisados os perfis proteicos, passamos para a identificação das proteínas exclusivas detectadas nos 3 grupos experimentais.

Foram selecionados os spots com densidade igual ou maior que 0,03 exclusivos de cada grupo (32 spots no grupo controle, 62 spots no grupo dos animais reserpinizados e 53 spots no grupo dos animais tratados com reserpina, fenilefrina e isoprenalina) para serem identificados e os géis representativos com os spots selecionados estão demonstrados nas Figuras 18A, B e C. 
Figura 18 - Gel 2-DE de SDS-poliacrilamida de extratos de glândulas parótidas de camundongos indicando os spots exclusivos selecionados nos 3 grupos experimentais que foram submetidos à espectrometria de massas.

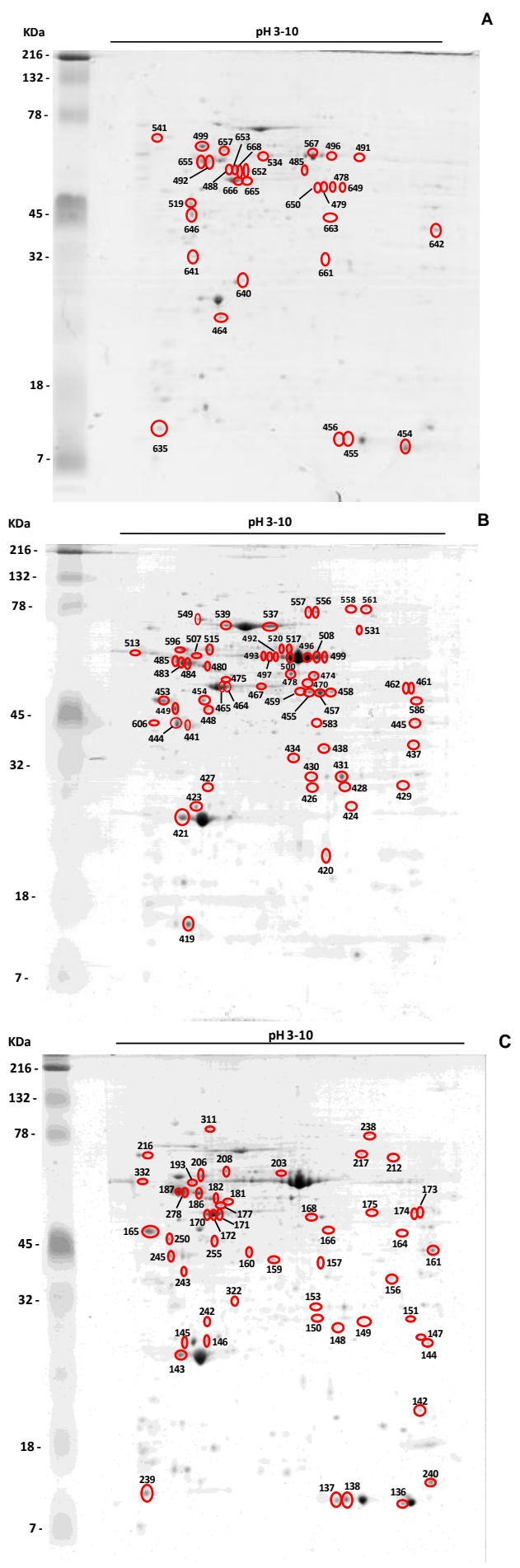

(A) Grupo Controle. (B) Grupo dos animais tratados com reserpina (0,5 mg/kg, i.p.). (C) Grupo dos animais tratados com reserpina $(0,5 \mathrm{mg} / \mathrm{kg}$, i.p.) e isoprenalina e fenilefrina $(20 \mathrm{mg} / \mathrm{kg}$, i.p). Os círculos vermelhos indicam os spots de proteínas exclusivos de cada condição que foram selecionados para serem identificados por espectrometria de massas. $\mathrm{N}=5$, em duplicata. 
Para identificação das proteínas, os spots de interesse foram recortados dos géis, descorados e digeridos com tripsina e os peptídeos resultantes foram submetidos à análise por nanoESI-LTQ/Orbitrap XL no Laboratório de Toxicologia do Instituto Oswaldo Cruz Fiocruz.

Desses spots selecionados, identificamos 309 proteínas no grupo controle, 612 proteínas no grupo dos reserpinizados e 361 proteínas no grupo dos animais tratados com reserpina e com os agonistas de adrenoceptores alfa e beta. Todas as informações sobre as proteínas identificadas estão nos Apêndices G, H e I e foram baseadas em informações coletadas no UniProt.

Em uma primeira abordagem as proteínas identificadas foram classificadas de acordo com suas localizações subcelulares. De acordo com essa análise, foram detectadas proteínas do citoplasma, mitocondriais, do retículo endoplasmático (RE), da membrana, do núcleo, do peroxissomo, do Golgi, do lisossomo e proteínas secretadas nos 3 grupos experimentais (Figuras 19A, B, C). Ao analisarmos as porcentagens de proteínas identificadas de cada compartimento subcelular em relação ao total identificado por grupo experimental, verificamos que houve diferença na porcentagem de proteínas citoplasmáticas, do núcleo, da mitocôndria e de proteínas secretadas após o tratamento crônico com reserpina. O número de espécies de proteínas identificadas como citoplasmáticas e nucleares diminuíram e as proteínas secretadas e mitocondriais aumentaram após tratamento crônico com reserpina e a posterior administração dos agonistas de adrenoceptores alfa e beta restauraram esses efeitos, sugerindo que a inervação simpática está regulando a síntese dessas proteínas em glândulas parótidas de camundongos.

Analisando as espécies de proteínas dos compartimentos celulares que tiveram alteração após o tratamento com reserpina, verificamos que o número de espécies de proteínas secretadas identificadas como chitinase, amilase-alfa, albumina, anidrase carbônica 6, serotransferrina e hemopexina aumentou após o tratamento crônico com reserpina e a administração de agonistas de adrenoceptores alfa e beta reverteu o efeito da reserpina (Figura 20). Estes dados sugerem que a reserpina bloqueou a exocitose dessas proteínas, ou que essas proteínas têm suas sínteses reguladas pela estimulação da inervação simpática. 
Figura 19 - Distribuição subcelular das espécies de proteínas exclusivas presentes nos extratos de glândulas parótidas de camundongos de cada grupo experimental identificadas por espectrometria de massas.
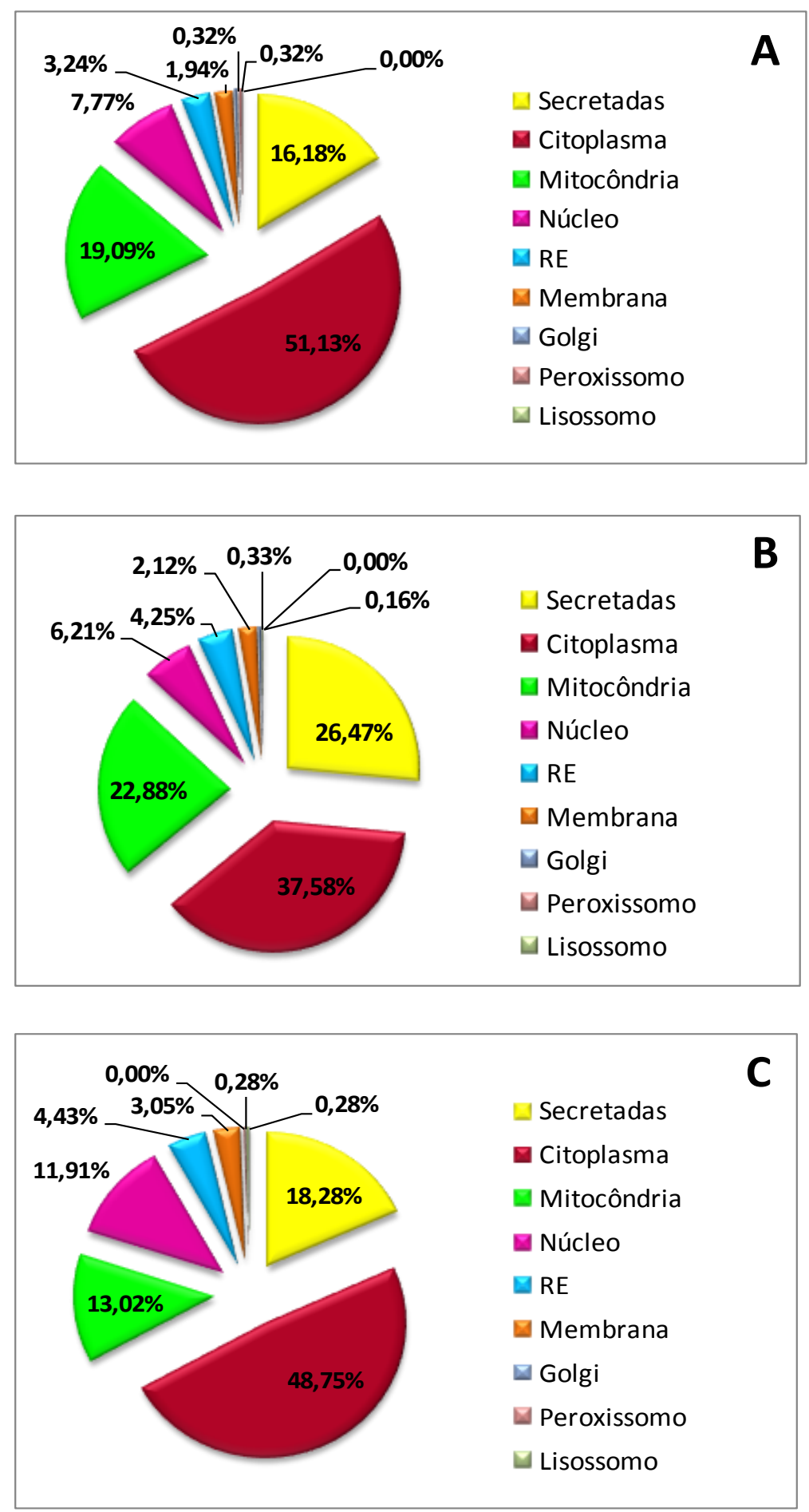

(A) Grupo controle. (B) Grupo dos animais tratados com reserpina. (C) Grupo dos animais tratados com reserpina, fenilefrina e isoprenalina. A classificação das proteínas foi obtida no banco de dados Uniprot. 
Figura 20 - Espécies de proteínas secretadas que foram reguladas pela inervação simpática.

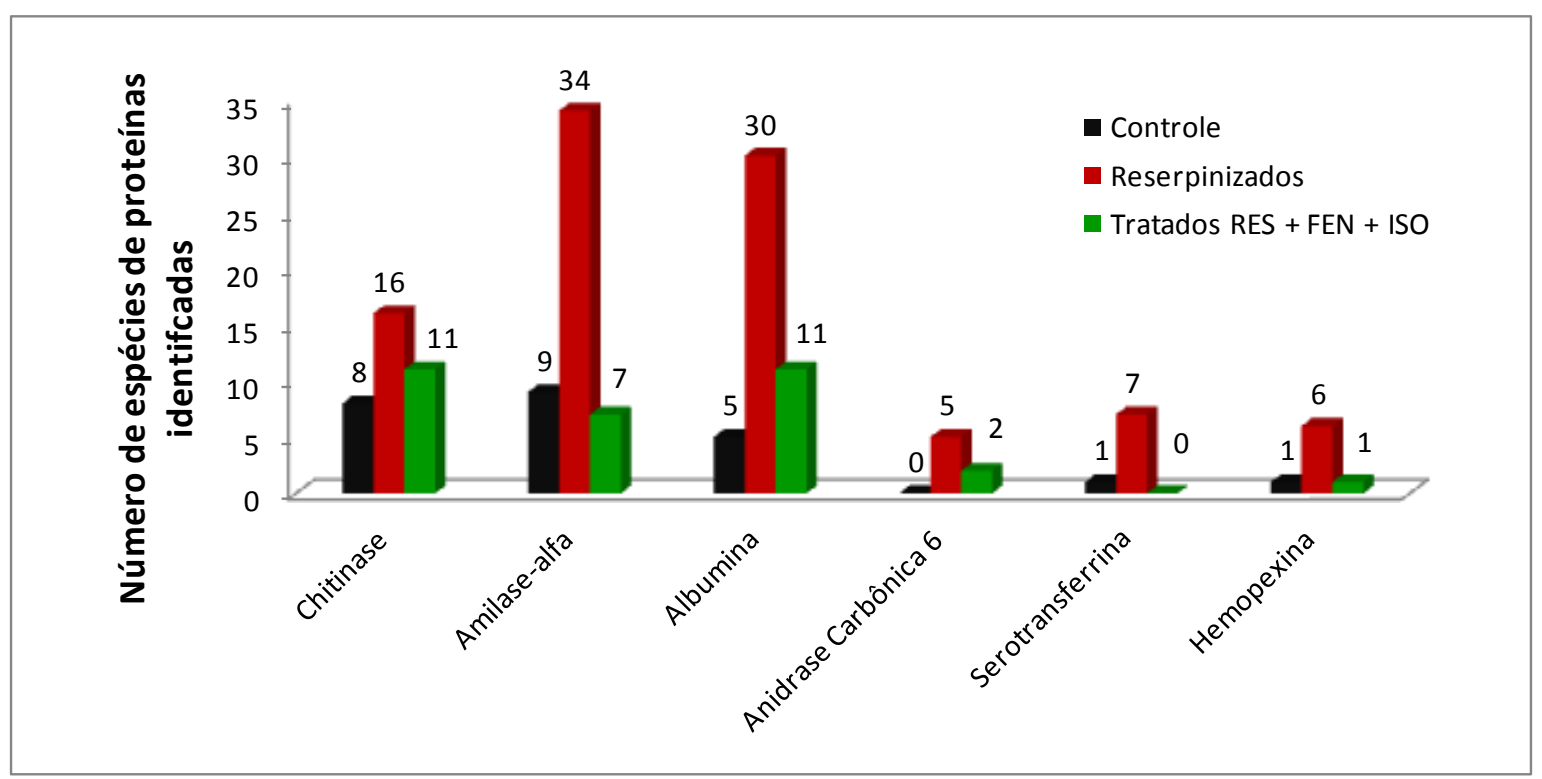

Espécies de proteínas secretadas que tiveram um aumento na sua quantidade após tratramento crônico com reserpina e posterior administração de agonistas de adrenoceptores reduziu esse número, voltando a ficar similar ao grupo controle. $\mathrm{RES}=$ reserpina; $\mathrm{FEN}$ = fenilefrina; $\mathrm{ISO}=$ isoprenalina.

Posteriormente, foi utilizada outra abordagem, na qual as proteínas identificadas nesse estudo foram classificadas de acordo com suas funções celulares (Figuras 21A, B, C).

Comparando as porcentagens de proteínas identificadas de acordo com suas funções, observamos que após o tratamento crônico com reserpina houve uma redução no número de espécies de proteínas envolvidas na organização do citoesqueleto, transcrição de proteínas, sinalização intracelular e na cadeia respiratória e um aumento do número de espécies de proteínas envolvidas nos processos biossintéticos, metabólicos e catabólicos. O efeito causado pela reserpina foi restaurado após administração de agonistas de adrenoceptores alfa e beta. Esses resultados sugerem que a inervação simpática também é importante na funcionalidade e manutenção da ativação das glândulas parótidas, regulando a síntese de proteínas envolvidas em diversos processos biológicos que são fundamentais para o funcionamento das glândulas parótidas de camundongos. 
Figura 21 - Distribuição das espécies de proteínas exclusivas presentes nos extratos de glândulas parótidas de camundongos de cada grupo experimental identificadas por espectrometria de massas de acordo com suas funções celulares.

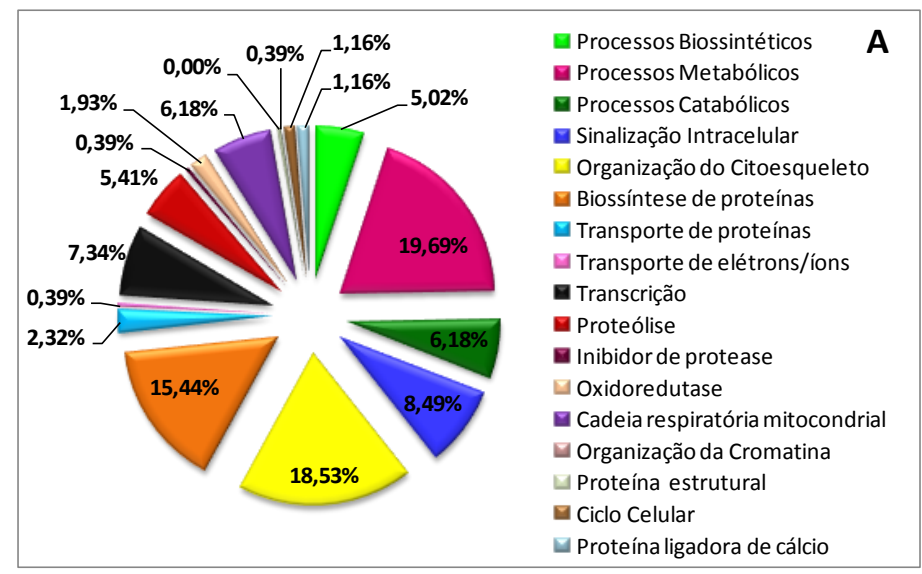

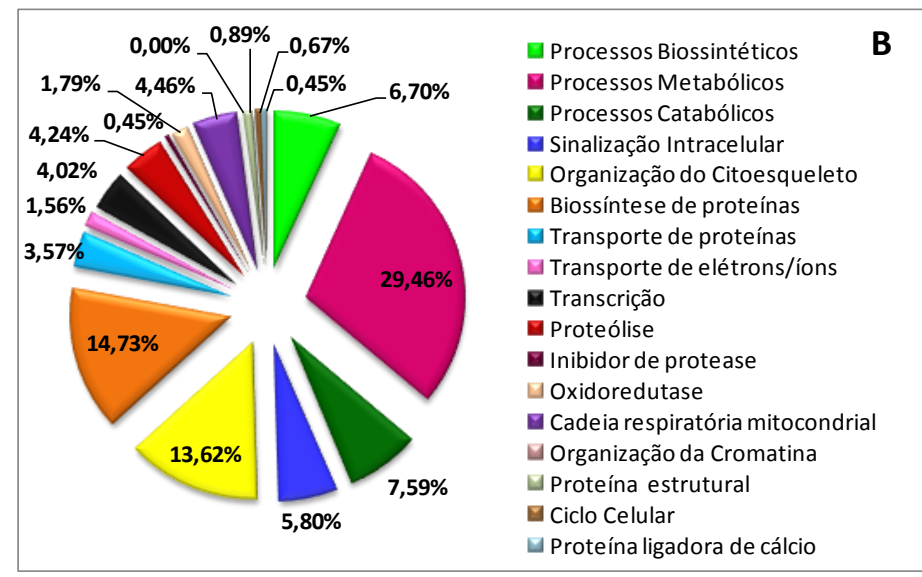

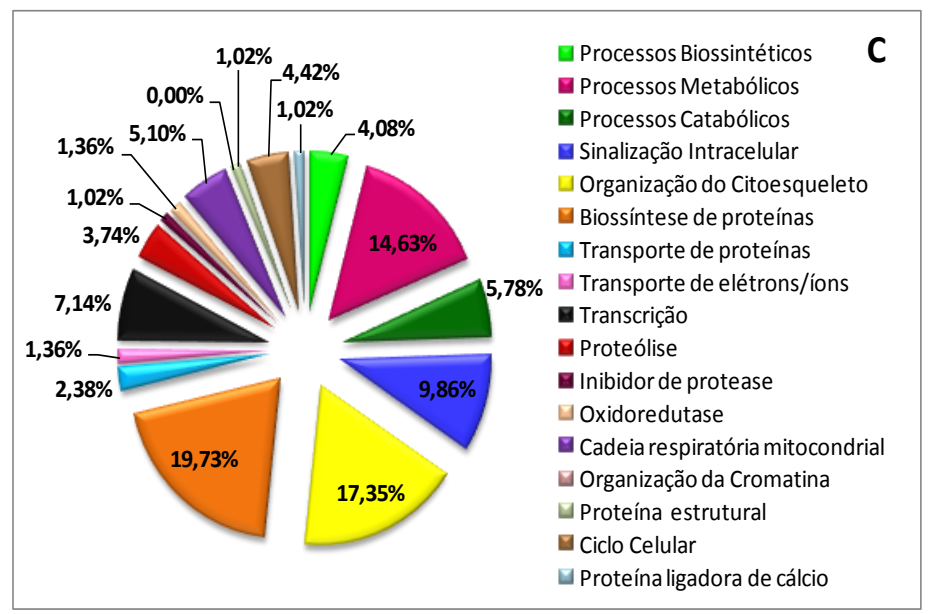

(A) Grupo controle, (B) do grupo dos animais tratados com reserpina, (C) grupo dos animais tratados com reserpina, fenilefrina e isoprenalina. A classificação das proteínas foi obtida no banco de dados Uniprot. 
5 DISCUSSÃO 
Nesse trabalho mostramos que o sistema nervoso simpático possui um papel importante nas glândulas salivares de camundongos regulando a síntese de diferentes proteínas envolvidas em processos biológicos que são fundamentais para a funcionalidade destas glândulas.

Utilizamos a reserpina como uma ferramenta farmacológica para verificar o papel da inervação simpática na funcionalidade das glândulas salivares de mamíferos. Dados da literatura mostram que o tratamento crônico com reserpina causa efeitos sobre os mecanismos de estímulo-secreção e provoca alterações morfológicas e funcionais semelhantes às observadas em pacientes com fibrose cística, ou seja, causa uma exocrinopatia obstrutiva, com posterior obstrução e dilação dos ductos, promovendo alterações no transporte de íons (MARTINEZ et al.,1975a,b; WATSON et al., 1984). De acordo com os nossos resultados, vimos que o tratamento crônico com reserpina foi capaz de promover alterações nos perfis proteicos de glândulas submandibulares e parótidas de camundongos quando comparados com os perfis proteicos das glândulas coletadas dos animais controle, indicando que a noradrenalina participa na regulação da síntese de proteínas dessas glândulas. Mostramos também que o efeito causado pela reserpina é reversível, visto que a administração de uma única dose de fenilefrina e isoprenalina, agonistas de adrenoceptores alfa e beta respectivamente, reverteu os efeitos causados pela reserpina. Portanto, a reserpina é uma ferramenta farmacológica importante para investigar o papel da inervação noradrenérgica em glândulas salivares de mamíferos.

Nossos resultados corroboram com os dados anteriores do nosso laboratório observados na glândula de veneno da serpente Bothrops jararaca, que é uma glândula oral exócrina relacionada com as glândulas salivares de mamíferos. Através da utilização de reserpina para depletar a noradrenalina endógena, viu-se que a inervação noradrenérgica é um dos principais fatores de ativação da glândula de veneno de serpentes Bothrops jararaca (KERCHOVE et al., 2004; LUNA et al., 2009; YAMANOUYE et al., 1997, 2000; ZABLITH, 2007). Ainda em glândulas de veneno, viu-se que o sistema nervoso simpático regula a expressão de diferentes proteínas ao longo dos estágios do ciclo de produção e secreção de veneno, e isso foi observado principalmente entre o quarto e sétimo dia do ciclo, os quais são considerados os estágios de maior atividade de síntese e secreção de proteínas do veneno (LUNA et al., 2009).

De acordo com Pinkstaff (1993), a composição da saliva primária é possivelmente única para cada glândula salivar e é determinada pela natureza das células secretoras dos ácinos e pelos elementos dos ductos. Existem diferenças significativas entre as glândulas salivares de 
diferentes espécies, bem como entre as diferentes glândulas salivares de uma mesma espécie. Além disso, os efeitos dos impulsos nervosos simpáticos e parassimpáticos sobre os processos de síntese e secreção de proteínas pelas glândulas salivares podem diferir entre as diferentes glândulas de uma mesma espécie, bem como na mesma glândula entre espécies diferentes e o volume e a composição das proteínas secretadas a partir de cada tipo de célula também podem variar dependendo da inervação que está sendo estimulada (EMMELIN, 1981; PROCTOR; CARPENTER, 2007). Comparando a saliva da glândula parótida e a saliva da glândula submandibular, Carpenter (2013) mostrou que algumas proteínas são secretadas por todas as glândulas como, por exemplo, o transportador de $\operatorname{IgA}$, já as proteínas básicas ricas em prolina são exclusivas da glândula parótida e as proteínas ácidas são exclusivas da glândula submandibular. Esses dados sugerem que cada glândula salivar possui mecanismos únicos que mantêm sua funcionalidade.

Nossos resultados corroboram com esta hipótese. Mostramos que a inervação simpática tem um papel importante nas glândulas submandibulares e parótidas de camundongos, mas atua de formas diferentes nestas glândulas. Estudos sobre a expressão gênica das glândulas maiores também mostram que elas expressam genes que codificam proteínas das glândulas, bem como de proteínas da saliva de formas distintas (NASHIDA et al., 2010).

Dados da literatura mostram que a inervação noradrenérgica tem papel apenas na estimulação da síntese e secreção de proteínas da saliva em mamíferos (BARKA, 1965a,b; BEDI, 1993; EDWARD; TITCHEN, 2003; LILLIE; HAN, 1973; QUISSELL; WATSON; DOWD, 1992; SHORI; ASKING, 2001; TEN HAGEN et al., 2002; VUGMAN; HAND, 1995). Além disso, alguns estudos avaliaram as proteínas e fluidos secretados de glândulas submandibulares de ratos em resposta à estimulação das inervações parassimpáticas e simpáticas (ANDERSON et al., 1995; GARRETT et al., 1991).

Vários estudos foram realizados mostrando a expressão gênica e síntese de proteínas secretadas após o tratamento com isoprenalina (ANN; LINN; KOUSVELARI, 1997; ANN; LINN, 1998; BARKA, 1965a,b; TEN HAGEN et al., 2002; VUGMAN; HAND, 1995), Em relação às glândulas salivares, Nashida et al. (2010) mostraram que o perfil de expressão gênica das glândulas submandibulares e parótidas diferem significativamente.

Os estudos proteômicos de glândulas salivares também enfocam somente os componentes da saliva (DENNY et al., 2008; HARDT et al., 2005; HU et al., 2005; SIQUEIRA et al., 2008). 
Neste trabalho, através de estudos proteômicos, mostramos que a estimulação da inervação simpática modula vários processos biológicos importantes para a manutenção da funcionalidade das glândulas submandibulares de camundongos. Foram realizadas três abordagens diferentes: 1) análise das espécies de proteínas exclusivas para cada grupo experimental; 2) análise dos spots comuns para os três grupos que apresentavam densidades 2 vezes maiores em pelo menos um dos grupos experimentais; 3 )análise dos spots comuns entre o grupo controle e o grupo dos animais tratados com reserpina, fenilefrina e isoprenalina, visto que o grupo controle corresponde à glândula no seu estado ativado e que a inervação simpática pode estar participando para manter a glândula neste estado de ativação. Através destas análises, verificamos que a estimulação da inervação simpática regula positivamente a síntese de espécies de proteínas relacionadas à organização do citoesqueleto, biossíntese de proteínas, proteólise, sinalização intracelular, processos biossintéticos e metabólicos, porém regula negativamente a síntese de outras espécies de proteínas relacionadas à organização do citoesqueleto, biossíntese de proteínas, processos biossintéticos e metabólicos.

Nas glândulas parótidas, analisando somente as espécies de proteínas exclusivas para cada grupo experimental, vimos que a estimulação da inervação simpática também modula vários processos biológicos importantes para a manutenção da funcionalidade das glândulas salivares. Verificamos que a estimulação da inervação simpática regula positivamente a síntese de espécies de proteínas relacionadas à organização do citoesqueleto, transcrição gênica, sinalização intracelular e cadeia respiratória, e regula negativamente a síntese de outras espécies de proteínas envolvidas em processos biossintéticos, metabólicos e catabólicos. Além disso, promove a exocitose das proteínas secretadas.

Analisando as proteínas secretadas das glândulas submandibulares e parótidas de camundongos, verificamos que somente nas glândulas parótidas a estimulação da inervação simpática levou à secreção de proteínas da saliva. A presença de espécies de proteínas secretadas como amilase, chitinase, albumina, anidrase carbônica 6, serotransferrina e hemopexina, observadas nas glândulas parótidas dos animais reserpinizados em uma quantidade muito maior do que as que foram observadas no grupo controle e no grupo dos animais tratados com reserpina e agonistas de adrenoceptores alfa e beta, sugerem que o sistema nervoso simpático é muito importante para o processo de exocitose das proteínas secretadas nas glândulas parótidas de mamíferos. Esse efeito causado pelo uso crônico da reserpina não foi evidenciado nas glândulas submandibulares. A glândula parótida contribui mais significativamente para a saliva total quando estimulada pelo paladar ou mastigação do 
que a glândula submandibular (MATSUO, 2000) e somando-se a isso o fato de que a estimulação da inervação simpática é um processo reflexo (PROCTOR; CARPENTER, 2007), podemos explicar essa diferença encontradaentre as glândulas salivares estudadas. Além dissso, a variação da densidade de inervação nas diferentes glândulas e a predominância dos subtipos de adrenoceptores encontrados em cada glândula contribuem para explicar este fato (EMMELIN, 1981).

Nas duas glândulas estudadas neste trabalho, a estimulação da inervação simpática parece ter um papel relevante na organização do citoesqueleto, ao modular a síntese de espécies de proteínas do citoesqueleto. Com relação às espécies de proteínas envolvidas com a organização do citoesqueleto, sabe-se que os microtúbulos são conhecidos por estarem envolvidos na manutenção da forma celular e no transporte intracelular (HIROKAWA, 1996, 1998; NOGALES, 2001). Nashida et al. (2004), mostraram que a tubulina beta, um dos constituintes dos microtúbulos, foi detectada em uma fração de glândulas submandibulares, indicando o envolvimento de microtúbulos no transporte dos grânulos de secreção por estimulação muscarínica. Além disso, a colchicina, uma droga que provoca a despolimerização de microtúbulos, inibe a secreção de amilase, o que é um indicativo de que a integridade dos microtúbulos é muito importante para secreção de amilase em glândulas parótidas. (PATZELT; BROWN; JEANRENAUD, 1977). Nas glândulas parótidas de ratos, isoprenalina, agonista do adrenoceptor beta, é a ferramenta secretagoga mais potente para liberação de amilase. O efeito desse agonista na secreção e nas proteínas do citoesqueleto envolve principalmente um aumento na concentração de cálcio citosólico e de AMPc (PERRIN et al., 1992).

Em glândulas submandibulares, foi descrito que a ruptura dos microfilamentos impede a liberação de amilase, mostrando que dessa forma, a actina, que é um dos constituintes dos microfilamentos, também é importante para o processo de exocitose em glândulas submandibulares (BUSCH; STERIN-BORDA; BORDA, 2002). Diferentemente das glândulas parótidas, o processo de secreção de amilase nas glândulas submandibulares não está relacionado com o acúmulo de AMPc e com o aumento da concentração de cálcio citosólico. Nesse caso, provavelmente, a exocitose da amilase é um fenômeno constitutivo não regulado, que depende somente da integridade dos microfilamentos (BUSCH; STERINBORDA; BORDA, 2002). Esses dados, somados aos nossos resultados, sugerem que diferentes espécies de proteínas do citoesqueleto são muito importantes para a regulação da 
secreção de proteínas em glândulas submandibulares e glândulas parótidas de mamíferos, seja uma secreção regulada ou uma secreção constitutiva.

A importância da inervação simpática na funcionalidade das glândulas salivares corrobora com o fato de que o tratamento com fenilefrina leva a uma melhora nas lesões estruturais e na função secretora de glândulas submandibulares transplantadas de coelhos, bem como aumenta a proliferação celular e inibe a apoptose em glândulas submandibulares irradiadas (XIANG et al., 2006, 2008).

Li et al. (2009) mostraram que a falta de estimulação dos adrenoceptores beta está envolvida na disfunção de glândulas submandibulares transplantadas. A administração de isoprenalina melhorou a injúria estrutural, bem como aumentou a função secretora das glândulas transplantadas, através do aumento de expressão dos adrenoceptores beta e beta $_{2}$ e subsequente aumento no conteúdo de AMPc intracelular e ativação de ERK1/2. O acúmulo de AMPc também leva à ativação de uma proteína cinase dependente de AMPc, resultando na liberação de uma grande quantidade de proteínas, tais como a amilase (PRASAD et al., 1993). Ainda, foi visto que administração de isoprenalina reduziu significativamente a atrofia das células acinares e aumentou a quantidade de grânulos secretórios no citoplasma das células acinares de glândulas transplantadas e aumentou a expressão da amilase alfa (LI et al., 2009).

É sabido que mais de $90 \%$ da atividade de síntese de proteínas das células acinares é dedicada à síntese de proteínas da secreção. Durante a biossíntese de proteínas, as proteínas salivares são transportadas para o lumen do retículo endoplasmático rugoso (RER). Os processos de dobramento e oligomerização das proteínas também são iniciados no RER. Estas complexas operações parecem ser auxiliadas por proteínas de ligação e por enzimas presentes no RER, como exemplo, a proteína dissulfeto isomerase (PDI) que catalisa as ligações dissulfeto (CASTLE, 1993; PELHAM, 1989).

O transporte das proteínas do RER para o Golgi requer energia, é sensível à temperatura, e provavelmente é mediado por transporte vesicular (BALCH, 1989). Essa energia requerida pelo Golgi e também necessária para as demais etapas do processo de síntese de proteínas vem principalmente da ação da cadeia respiratória Paralelo a isso, nos nossos resultados mostramos que a inervação simpática está regulando positivamente a síntese de proteínas envolvidas na cadeia respiratória em glândulas parótidas.

Patzelt, Brown e Jeanrenaud (1997) mostraram que há o envolvimento de proteínas dos microtúbulos no transporte vesicular do RER até o Golgi em células acinares da parótida. Além disso, alguns autores mostraram que o Golgi é responsável por realizar uma grande 
variedade de modificações pós-traducionais em proteínas secretadas, lisossomais e proteínas de membrana (ROOTHMAN, 1987; TOOZE et al., 1988). Esses processos relacionados à síntese de proteínas são indicativos da funcionalidade das glândulas salivares. Levando-se em conta o fato de que nessa Dissertação mostramos que a inervação simpática está regulando positivamente a síntese de proteínas envolvidas nesses processos biológicos na glândula submandibular e na glândula parótida de camundongos, sugerindo que a inervação simpática possua um papel relevante para a funcionalidade das glândulas submandibulares e parótidas, modulando vários processos biológicos, fundamentais para a manutenção dessas glândulas em seus estágios ativados. Mas vale ressaltar que essa inervação atua de maneira diferenciada nas glândulas submandibulares e parótidas.

Mostramos então que a estimulação da inervação noradrenérgica é muito importante para a funcionalidade das glândulas salivares, bem como para a síntese e secreção de saliva, no caso das glândulas parótidas. A estimulação desta inervação pode ser de extrema importância para a produção de saliva em casos de xerostomia (falta de saliva, "boca seca") decorrente de disfunções das glândulas salivares, devido principalmente a longos tratamentos de quimio/radioterapia para terapias de câncer de cabeça e pescoço, efeitos de medicamentos, desequilíbrio do sistema nervoso autônomo, como também de doenças como a síndrome de Sjögren, que leva à deteriorização da mucosa da boca e da traquéia. Porém, os tratamentos para essas disfunções das glândulas salivares ainda são paliativos (BROSKY, 2007; VON BÜLTZINGSLÖWEN et al., 2007).

Para reduzir e reverter os sintomas da xerostomia, dados da literatura mostram a utilização de um tratamento à base de água seguido de uma mistura salina, porém o uso prolongado desta mistura pode remover pequenas quantidades de muco da saliva, resultando no aumento da sensação de ressecamento da boca e na diminuição de agentes protetores presentes na saliva, como a mucina (para revisão DELALEU et al., 2005). Foi visto também que o uso de agonistas dos receptores muscarínicos como a pilocarpina e a cevimelina e a administração oral de INF-alfa têm demonstrado levar a uma melhora local e sistêmica dos sintomas da Síndrome de Sjögren, promovendo um aumento no fluxo de saliva (BROSKY, 2007; DELALEU et al., 2005; FOX et al., 2001; PELUSO et al., 2007; VON BÜLTZINGSLÖWEN et al., 2007).

Estudos de proteômica e genômica em glândulas salivares têm sido utilizados como ferramentas muito promissoras para desvendarem a fisiopatologia de várias doenças, como a Síndrome de Sjögren, proporcionando assim uma visão mais profunda do que está ocorrendo 
nas patologias, contribuindo para a descoberta de terapias de intervenção mais eficazes, no entanto, em casos de doenças de glândulas salivares, é difícil identificar qual glândula está afetada, pelo fato de que o perfil de proteínas de cada glândula ainda não está bem estabelecido.

Nossos dados mostram claramente que cada glândula salivar responde de uma forma à estimulação simpática e o conhecimento das proteínas que têm suas expressões reguladas pela atividade simpática pode contribuir de forma significativa para a compreensão das disfunções das glândulas salivares, bem como, para um possível desenvolvimento de novos fármacos para o tratamento dessas disfunções orais que atualmente carecem de tratamentos que sejam eficazes. 


\section{CONCLUSÃO}


Em resumo, os resultados obtidos mostraram que:

- Tratamento crônico com reserpina alterou a densidade de algumas bandas: reduziu em glândulas submandibulares, similar ao que foi visto em glândulas de veneno de Bothrops jararaca (LUNA et al., 2009), e aumentou em glândulas parótidas. Administração de agonistas de adrenoceptores restaurou os efeitos da reserpina em ambas as glândulas.

- Identificação das proteínas em glândulas submandibulares: inervação simpática regulou a síntese de proteínas mitocondriais e nucleares e de proteínas envolvidas principalmente na organização do citoesqueleto e na biossíntese de proteínas.

- Identificação das proteínas presentes nos 3 grupos experimentais de glândulas submandibulares de camundongos: inervação simpática tem um papel relevante para homeostase celular bem como na síntese e secreção de várias proteínas.

- Identificação das proteínas em glândulas parótidas: inervação simpática regulou a síntese de proteínas citoplasmáticas, mitocondriais, nucleares e secretadas, bem como de proteínas envolvidas na organização do citoesqueleto, transcrição de proteínas, sinalização intracelular e com participação na cadeia respiratória mitocondrial.

Em conclusão, os resultados sugerem que a inervação simpática possui um importante papel para funcionalidade das glândulas salivares de camundongos, isto é, mantendo a glândula em constante estado de ativação, regulando a síntese de diferentes proteínas dessas glândulas ou promovendo a exocitose de proteínas da saliva. Além disso, os resultados mostram que a inervação simpática atua de maneira diferente nas glândulas submandibulares e parótidas de camundongos. 


\section{REFERÊNCIAS}




\section{REFERÊNCIAS $^{3}$}

AMBUDKAR, I. S.; BAUM, B. J. ATP-dependent calcium transport in rat parotid basolateral membrane vesicles is modulated by membrane potential. J. Membr. Biol., v. 102, p. 59-72, 1988.

ANDERSON, L. C.; GARRETT, J. R.; ZHANG, X.; PROCTOR, G. B.; SHORI, D. K. Differential secretion of proteins by rat submandibular acini and granular ducts on graded autonomic nerve stimulations. J. Physiol., v. 485, n. 2, p. 503-511, 1995.

ANN, D. K.; LIN, H. H.; KOUSVELARI, E. Regulation of salivary-gland-specific gene expression. Crit. Rev. Oral Biol. Med., v. 8, n. 3, p. 244-252, 1997.

ANN, D. K.; LIN, H. H. Transcriptional regulation of salivary proline-rich protein gene expression. Ann. NY Acad. Sci., v. 842, p. 108-114, 1998.

BALCH, W. E. Biochemistry of interorganelle transport. J. Biol. Chem., v. 264, p. 169, 1989.

BARKA, T. Biologically active polypeptides in submandibular glands. J. Histochem. Cytochem., v. 28, p. 836-859, 1980.

BAUM, B. J.; FREIBURG, J. M.; ITO, H.; ROTH, G. S.; FILBURN, C. R. Beta-adrenergic regulation of protein phosphorylation and its relationship to exocrine secretion in dispersed parotid gland acinar cells. J. Biol. Chem., v. 256, n. 18, p. 9731-9736, 1981.

BAUM, B. J. Regulation of salivary secretion. In: SREEBNY, L.M. (Ed.). The salivary system. BocaRaton, FL: CRC Press Inc, 1987. p. 123-134.

BAUM, B. J. Principles of saliva secretion. Ann. N.Y. Acad. Sci., v. 694, p. 17-23, 1993.

BAUM, B. J.; WELLNER, R. B. Neural mechanisms of salivary gland and secretion: receptors in salivary glands. In: Front oral biology. Basel: Karger, 1999. v. 11, p. 44-58.

BERNARDI, R.; PERIN, C.; BECKER, F. L.; RAMOS, G. Z.; CHENO, G. Z.; LOPES, L. R.; PIRES, M.; BARROS, H. M. Effects of pilocarpine mouth wash on salivary flow. Braz. J. Med. Biol. Res., v. 35, p. 105-110, 2002.

BEDI, G. S. the effect of adrenergic agonists and antagonists on the expression of proteins in rat submandibular and parotid glands. Crit. Rev. Oral Biol. Med., v. 4, n. 3, p. 565-561, 1993.

BDOLAH, A. The venom glands of snakes and venom secretion. In: LEE, C.Y. (Ed.). Snake venom. Berlin: Spring Verlag, Handbook Experimental Pharmacology, 1979. v. 52, p. 41-57.

${ }^{3}$ De acordo com:

ASSOCIAÇÃO BRASILEIRA DE NORMAS TÉCNICAS. NBR 6023: informação e documentação: referências: elaboração. Rio de Janeiro, 2002. 
BOGART, B. I. Secretory dynamics of the rat submandibular gland. An ultrastructural and cytochemical study of the isoproterenol-induced secretory cycle. J. Ultrastruct. Res., v. 52, p. 139-155, 1975.

BRADFORD, M. A rapid and sensitive method for the quantification of micrograms quantities of protein utilizing the principle of protein-dye binding. Anal Biochem., v. 72, p. 248-254, 1976.

BROSKY, M. E. The role of saliva in oral health: strategies for prevention and management of xerostomia. J. Support. Oncol., v. 5, p. 215-225, 2007.

BUSCH, L.; STERIN-BORDA, L.; BORDA, E. Differences in the regulatory mechanism of amylase release by rat parotid and submandibular glands. Arch. Oral Biol., v. 47, p. 717-722, 2002.

BYLUND, D. B.; FORTE, L. R.; MORGAN, D. W.; MARTINEZ, J. R. Effects of chronic reserpine administration on $\beta$ adrenergic receptors, adenylate cyclase and phosphodiesterase of the rat submandibular gland. J. Pharmacol., v. 218, p. 134-141, 1981.

CAMPRÉCIÓS, G.; NAVARRO, M.; SOLEY, M.; RAMIREZ, I. Acute and chronic adrenergic stimulation of submandibular salivary glands. Effects on the endocrine function of epidermal growth factor in mice. Growth Factors, v. 27, n. 5, p. 300-308, 2009.

CARNEIRO, S. M.; PINTO, V. R.; JARED, C.; LULA, L. A. B. M.; FARIA, F. P.; SESSO, A. Morphometric studies on venom secretory cells from Bothrops jararacussu (jararacuçu) before and after venom extraction. Toxicon, v. 29, n. 6, p. 569-580, 1991.

CARPENTER, G. H. The secretion, components, and properties of saliva. Annu. Rev. Food Sci. Technol., v. 4, p. 267-276, 2013.

CASTLE, D. Cell biology of salivary protein secretion. In: VERGONA, K. D. (Ed.). Biology of the salivary glands. Boca Raton: CRC Press, 1993. p. 81-104.

DANIELS, T. E.; WU, A .J. Xerostomia - clinical evaluation and treatment in gneral practice. J. Calif. Dent. Assoc., v. 28, p. 933-941, 2000.

D’AMICO, F.; SKARMOUTSOU, E.; MANGANO, K.; MALAPONTE, G.; STIVALA F.; MAZZARINO, M. C. Expression and localization of prominin-1 in isoproterenol-treated rat parotid gland. International J. of Molec. Med., v. 26, p. 505-510, 2010.

DELALEU, N.; JONSSON, R.; KOLLER, M. M. Sjögren's syndrome. Eur. J. Oral Sci., v. 113, p. 101-113, 2005.

DENNY, P. et al. The proteomes of human parotid and submandibular/sublingual gland salivas collected as the ductal secretions. J. Proteome Res., v. 7, p. 1994-2006, 2008.

EDWARDS, A. V.; TITCHEN, D. A. Autonomic control of protein production by the parotid gland of the sheep. Auton. Neurosc. Bas. Cli, v. 103, p. 38-49, 2003. 
EMMELIN, N. Nervous control of mammalian salivary glands. Phil. Trans. R. Soc. Lond. B., v. 296, p. 27-35, 1981.

EKFORS, T.; CHANG, W. W. L.; BRESSLER, R. S.; BARKA, T. Isoproterenol accelerates the postnatal differentiation of rat submandibular gland. Develop. Biol., v. 29, p. 38-47, 1972.

EKSTROM, J. Neuropeptides and secretion. J. Dent. Rev., v. 66, p. 524-530, 1987.

EKSTROM, J.; EKMAN, R.; HAKASON, R.; LUTS, A.; SUNDLER, F.; TOBIN, G. Effects of capsaicin pretreatment on neuropeptides and salivary secretion of rat parotid glands. Br. J. Pharmacol., v. 97, p. 1031-1038, 1989.

ELVERDIN, J. C.; LUCHELLI-FORTIS, M. A.; STEFANO, F. J. E.; PEREC, C. J. Alpha-1 adrenoceptors mediate secretory responses to norepinephrine in innervated and denervated rat submaxillary glands. J. Pharmacol. Exp. Therap., v. 229, p. 261-266, 1994.

FERGUSON, M. M. Pilocarpine and other cholinergic drugs in the management of salivary gland dysfunction. Oral Surg. Oral Med. Oral Pathol., v. 75, p. 186-191, 1993.

FOX, R. I.; KONTTINEN, Y.; FISHER, A. Use of muscarinic agonists in the treatment of Sjögren's syndrome.Clin. Immunol., v. 101, p. 249-263, 2001.

GARRETT, J. R.; THULIN, A. Changes in parotid acinar cells accompanying salivary secretion in rats on sympathetic or parasympathetic nerve stimulation. Cell Tissue Res., v. 159, p. 179-193, 1975.

GARRETT, J. R.; EMMELIN, N. Activities of salivary myoepithelial cells: a review. Med. Biol., v. 57, n. 1, 1979.

GARRETT, J. R. Adventures with autonomic nerves. Perspectives in salivary glandular innervations. Proc. R. Micr. Soc., v. 17, p. 242, 1982.

GARRETT, J. R. The proper role of nerves in salivary secretion - a review. J. Dent. Res., v. 66, p. 387-397, 1987.

GARRETT, J. R.; ANDERSON, L. C. Rat sublingual salivary glands - secretory changes on parasympathetic or sympathetic-nerve stimulation and a reappraisal of the adrenergic inervation of striated ducts. Arch. Oral Biol., v. 36, n. 9, p. 675-683, 1991.

GARRETT, J. R.; SUlEIMAN, A. M.; ANDERSON, L. C.; PROCTOR, G. B. Secretory responses in granular ducts and acini of submandibular glands in vivo to parasympathetic or sympathetic-nerve stimulation in rats. Cell and Tissue Res., v. 264, n. 1, p. 117-126, 1991.

GAUTAM, D. HEARD, T. S.; CUI, Y. H.; MILLER, G.; BLOODWORTH, L.; WESS, J. Cholinergic stimulation of salivary secretion studied with M1 and M3 muscarinic receptor single- and double-knockout mice. Molec. Pharmacol., v. 66, n. 2, p. 260-267, 2004.

GLASS, B. J.; VAN-DIS, M. L.; LANGLAIS, R. P.; MILE, D. A. Xerostomia: diagnosis and treatment planning considerations. Oral Surg., v. 58, n.2, p. 248-252, 1984. 
HARDT, M. et al. Toward defining the human parotid gland salivary proteome and peptidome: identification and characterization using 2D SDS-PAGE, ultrafiltration, HPLC, and mass spectrometry. Biochemistry, v. 44, p. 2285-2899, 2005.

HAY, D. I.; BOWEN, W. H. In: EDGAR, W.; O'MULLANE, D. (Ed.). The functions of salivary proteins. Thanet Press, 1999. v. 8.

HIROKAWA, N. The molecular mechanism of organelle transport along microtubules: the identification and characterization of KIFs (Kinesin superfamily proteins). Cell Struct. Funct., v. 21, p. 357-367, 1996.

HIROKAWA, N. Kinesin and dynein superfamily proteins and the mechanism of organelle transport. Science, v. 279, p. 519-526, 1998.

$\mathrm{HU}$, S. et al. Large-scale identification of proteins in human salivary proteome by liquid chromatography/mass spectrometry. Proteomics, v. 5, p. 1714-1728, 2005.

HUANG, Z.; WU, L.L.; ZHANG, Y.Y.; GAO, Y.; YU, G.Y. Functional $\alpha 1$ - adrenoceptor subtypes in human submandibular glands. J. Dent. Res., v. 85, n. 3, p. 251-256, 2006.

JENSEN, J. L.; BRODIN, P.; BERG, T.; AARSH, H. Parotid secretion of fluid amylase and kallikrein during reflex stimulation under normal conditions and after acute administration of autonomic blocking agents in man. Acta. Physiol. Scand., v. 143, p. 321-329, 1991.

JIANG, L.; HE, L.; FOUNTOULAKIS, M. Comparison of protein precipitation methods for sample preparation prior to proteomic analysis. J. Chromatogr., v. 1023, n. 2, p. 317-320, 2004.

KARDONG, K. V. The evolution of snakes apparatus in snakes from colubrids to viperids \& elapids. Mem. Inst. Butantan, v. 46, p. 105-118, 1982.

KERCHOVE, C. M.; CARNEIRO, S. M.; MARKUS, R. P.; YAMANOUYE, N. Stimulation of $\alpha$-adrenoceptor triggers the venom production cycle in the Bothrops jararaca venom gland. J. Exp. Biol., v. 207, p. 411-416, 2004.

KERCHOVE, C. M.; LUNA, M. S. A.; ZABLITH, M. B.; SMAILL, S. S.; YAMANOUYE, $\mathrm{N}$. Alpha-adrenoceptor triggers snake venom production cycle in secretory cells by activating phosphatidylinositol4,5-biphosphate hydrolysis and ERK signaling pathway. Comp. Biochem. Physiol., v. 150, p. 431-437, 2008.

KLEIN, R. M. Development, strutcture and function of the salivary glands. In: AVERY, J. K. (Ed.). Oral development and history. Stuttgart: Thieme, 2002. p. 321-330.

KOCHVA, E.; GANS, C. The structure of the venom gland and secretion of venom in viperid snakes. In: REWELL, F.E.; RUSSELL, P.R. Animal toxins. Oxford: Pergamon Press, 1967. p. $195-203$.

KOCHVA, E.; GANS, C. Salivary glands of snakes. Clin. Toxicol., v. 3, p. 363-387, 1970. 
KOCHVA, E. Oral glands of reptilia. In: GANS, C.(Ed.). Biology of the reptilia. London: Academic Press, 1978. v. 8b, p. 43-161.

KOCHVA, E. The origin of snakes and evolution of the venom apparatus. Toxicon, v. 25, p. 65-106, 1987.

LAEMMLI, U. K. Cleavage of structural proteins during the assembly of the heat of bacteriophage T4. Nature, v. 227, n. 5259, p. 680-685, 1970.

LI, Y. M.; ZHANG, Y.; XIANG, B.; ZHANG, Y. Y.; WU, L. L.; YU, G. Y. Expression and functional analysis of $\beta$-adrenoceptor subtypes in rabbit submandibular gland. Life Sci., v. 79, p. 2091-2098, 2006.

LI, Y. M.; ZHANG, Y.; SHI, L.; XIANG, B.; CONG, X.; ZHANG, Y. Y.; WU, L. L.; YU, G. Y. Isoproterenol improves secretion of transplanted submandibular glands. J. Dent. Res., v. 88, n.5, p. 477-482, 2009.

LILLIE, J. H.; HAN, S. S. Secretory protein synthesis in the stimulated rat parotid gland. Temporal dissociation of the maximal response from secretion. J. Cell Biol., v. 59, p. 708$721,1973$.

LUNA, M. S. A.; HORTENCIO, T. M. A.; FERREIRA, Z. S.; YAMANOUYE, N. Sympathetic outflow activates the venom gland of the snake Bothrops jararaca by regulating the activation of transcription factors and the synthesis of venom gland proteins. J. Exp. Biol., v. 212, p. 1535-1543, 2009.

MACKESSY, S.P. Morphology and ultrastructure of the venom gland of the northern Pacific rattlesnake Crotalus viridis oreganus. J. Morph., v. 208, p. 109-128, 1991.

MANDEL, I. D.; WOTMAN, S. The salivary secretions in health and disease. Oral Sci. Rev., v. 8 , p. 25-47, 1976.

MARTINEZ, J. R.; ADSHEAD, P. C.; QUISSELL, D. O.; BARBERO, G. J. The chronically reserpinized rats as a possible model for cystic fibrosis. I. Submaxillary gland morphology and ultrastructure. Pediatr. Res., v. 9, p. 463-469, 1975a.

MARTINEZ, J. R.; ADSHEAD, P. C.; QUISSELL, D. O.; BARBERO, G. J. The chronically reserpinized rats as a possible model for cystic fibrosis. II. Comparison and inhibitory effects of submaxillary saliva. Pediatr. Res., v. 9, p. 470-475, 1975 b.

MARTINEZ-OLIVARES, R.; VILLANUEVA, I.; RACOTTA, R.; PIÑON, M. Depletion and recovery of catecholamines in several organs of rats treated with reserpine. Auton. Neurosci. Basic Clin., v. 128, p. 64-69, 2006.

MATSUO, R. Role of saliva in the maintenance of taste sensivity. Crit. Ver. Oral Biol. Med., v. 11, n. 2, p. 216-222, 2000.

MELGAREJO, A. R. Serpentes peçonhentas do Brasil. In: Animais peçonhentos no Brasil: biologia, clínica e terapêutica dos acidentes. São Paulo: Sarvier, 2003. p. 33-61. 
MELVIN, J. E.; YULE, D.; SHUTTTLEWORTH, T.; BEGENISICH, T. Regulation of fluid and electrolyte secretion in salivary gland acinar cells. Annual Rev. Physiol., v. 67, p. 445469, 2005.

MORENO, M.; MAQUEDA, I.; NARANJO, J. A.; MARTINEZ, E. V. Influence of superior cervical ganglion stimulation frequency on salivary secretion in the rabbit. Comparative study of parotid and submandibular glands. Rev. Esp. Fisiol., v. 42, p. 489-496, 1986.

NAKAMURA, T.; MATSUI, M.; UCHIDA, K.; FUTATSUGI, A.; KUSAKAWA, S.; MATSUMOTO, N.; NAKAMURA, K.; MANABE, T.; TAKETO, M. M. M3 muscarinic acetylcholine receptor plays a critical role in parasympathetic control of salivation in mice. $\mathbf{J}$. Physiol., v. 558, n. 2, p. 561-575, 2004.

NASHIDA, T.; YOSHIE, S.; IMAI, A.; SHIMOMURA, H. Presence of cytoskeleton proteins in parotid glands and their roles during secretion. Arch. Oral Biol., v. 49, p. 975-982, 2004.

NASHIDA, T.; SATO, R.; IMAI, A.; SHIMOMURA, H. Gene expression profiles of the three major salivary glands in rats. Biomed. Research, v. 31, n. 6, p. 387-399, 2010.

NISHIURA, T.; GAO, C.; ABE, N. K. Expression and postnatal changes of adrenergic receptor subtype mRNA in rat submandibular glands. Arch. Oral Biol., v. 46, p. 573-584, 2001.

NOGALES, E. Structural insights into microtubule function. Annu. Rev. Biomol. Struct., v. 30, p. 397-420, 2002.

PATZELT, C.; BROWN, D.; JEANRENAUD, B. Inhibitory effect of colchicines on amylase secretion by rat parotid glands. J. Cell Biol., v. 73, p. 578-593, 1977.

PELHAM, H. R. B. Control of protein exit from the endoplasmic reticulum. Annu. Rev. Cell Biol., v. 5, p. 1-13, 1989.

PELUSO, G.; DE SANTIS, M.; INZIATARI, R.; FANALI, C.; CABRAS, T.; MESSANA, I.; CASTAGNOLA, M.; FERRACCIOLI, G. F. Proteomic study of salivary peptides and proteins in patients with Sjögren syndrome before and after pilocarpine treatment. Arthritis Rheum., v. 56, p. 2216-2222, 2007.

PERRIN, D.; MÖLLER, K.; HANKE, K.; SÖLING, H. D. cAMP and $\mathrm{Ca}^{2+-}$ mediated secretion in parotid acinar cells is associated with reversible changes in the organization of the cytoskeleton. J. Cell Biol., v. 116, n. 1, p. 127-134, 1992.

PINKSTAFF, C. A. The cytology of salivary glands. Internatl. Rev. Cytol., v. 63, p. 141261, 1980.

PINKSTAFF, C. A. Cytology, histology, and histochemistry of salivary glands: and overview. In: VERGONA, K. D. (Ed.). Biology of the salivary glands. Boca Raton: CRC Press, 1993. p. 15-38. 
PRASAD, K. N.; CARVALHO, E.; KUMAR, S.; EDWARDS-PRASAD, J.; LA ROSA, F. G. Relationship between adenosine 3', 5'-cyclic monophosphate level, cell proliferation, and alpha amylase in rat parotid. Biochem. Cell Biol., v. 71, p. 355-360, 1993.

PROCTOR, G. B. Secretory protein synthesis and constitutive (vesicular) secretion by salivary glands. In: GARRETT, J.R.; EKSTROM, J.; ANDERSON, L.C. (Ed.). Glandular mechanisms of salivary secretion. Basel: Karger, 1998. p. 73-88.

PROCTOR, G. B.; CARPENTER, G. H. Regulation of salivary gland function by autonomic nerves.Auton. Neurosci. Basic Clin., v. 133, p. 3-18, 2007.

QUISSEL, D. O.; WATSON, E.; DOWD, F. J. Signal transduction mechanisms involved in salivary gland regulated exocytosis. Crit. Rev. Oral Biol. Med., v. 3, p. 83-107, 1992.

QUISSELL, D. O.; BARZEN, K. A.; DEISHER, L. M. Rat submandibular and parotid protein phosphorylation and exocytosis: Effect of site-selective camp analogs. Crit. Rev. Oral Biol. Med., v. 4, p. 443-448, 1993.

RAUBENHEIMER, E. J.; NIEKERK, J. P.; HAUMAN, C. H. J. Salivary myoepithelium: distribution, structure, functions and pathologic proliferations. J. Dent. Assoc. South Africa, v. 42, p. 631-637, 1987.

ROTHMAN, J. E. Protein sorting by selective retention in the endoplasmic reticulum and Golgi stack. Cell, v. 50, p. 521, 1987.

SALOMÃO, M. G. Estrutura e secreção das glândulas de Duvernoy de Sibynomorphus mikani (Colubridade, Dipsadinae) e Philodryas olfersii (Colubridade, Xenodontinae), e das glândulas de veneno de Bothrops jararaca (Viperidade, Crotalinae) e Micrurus frontalis (Elapidae, Elapinae) e a influência dos estados de alimentação e jejum. $122 \mathrm{f}$. Tese (Doutorado em Zoologia) - Instituto de Biociências, Universidade de São Paulo, São Paulo, 1991.

SARACCO, C. G.; CRABILL, E. V.Anatomy of the human salivary glands. In: VERGONA, K. D. (Ed.). Biology of the salivary glands. Boca Raton: CRC Press, 1993. p. 1-14.

SCHNEYER, L. H.; YOUNG, J. A.; SCHNEYER, C. A. Salivary secretions of electrolytes. Physiol. Rev., v. 52, p. 720-777, 1972.

SEGAWA, A.; YAMASHINA, S. The dynamics of exocytosis of preformed secretory granules from acini in rat salivary glands. In: GARRETT, J. R.; EKSTROM, J.; ANDERSON, L. C. (Eds.). Glandular mechanisms of salivary secretion. Basel: Karger, 1998. p. 89-100.

SHAW, P. A.; BARKA, T.; WOODIN, A.; SCHACTER, B. S.; COX, J. L. Expression and induction by beta-adrenergic agonists of the cystatin $\mathrm{S}$ gene in submandibular glands of developin rats. Biochem. J., v. 265, p. 115-120, 1990.

SHEAR, M. The structures and function of myoepithelial cells in salivary glands. Arch. Oral Biol., v. 11, p. 769-781, 1966. 
SHORI, D. K.; ASKING, B. Dynamics of protein and fluid secretion from the major salivary glands of rat: relevance of research findings to clinically observed defective secretion in cystic fibrosis. Eur. J. Physiol., v. 443, n.1, p. S11-S16, 2001.

SIQUEIRA, W. L.; SALIH, E.; WAN, D. L.; HELMERHORST, E. J.; OPPENHEIM, F. G. Proteome of human minor salivary gland secretion. J. Dent. Res., v. 87, p. 445-450, 2008.

STITZEL, R. E. The biological fate of reserpine. Pharmacol. Rev., v. 28, p. 179-208, 1977.

STREB, H.; IRVINE, R. F.; BERRIDGE, N. J.; SCHULZ, I. Release of $\mathrm{Ca}^{2+}$ from a nonmitochondrial intracellular store in pancreatic acinar cells by inositol 1,4,5-triphosphate.

Nature, v. 306, p. 67, 1983.

TANDLER, B. Salivary glands and the secretory process. In: SHAW, J. H.; SWEENEY, E. A.; CAPPUCINO, C. C.; MELLER, S. M. (Eds.). Textbook of oral biology. Philadelphia: Saunders Co., 1978. p. 547.

TANDLER, B. Structure of the duct system in mammalian major salivary glands. Microsc. Res. Tech., v. 26, p. 57-74, 1993.

TANDLER, B.; PHILLIPS, C. J. Microstructure of mammalian salivary glands and its relationship to die. In: GARRETT, J. R.; EKSTROM, J.; ANDERSON, L. C. (Eds.). Glandular mechanisms of salivary secretion. Basel: Karger, 1998. p. 21-35.

TEN CATE, A. R. In: Histologia bucal: desenvolvimento, estrutura e função. 5 . ed. Rio de Janeiro: Guanabara Koogan, 2001. 439 p.

TEN HAGEN, K. G.; BALYS, M. M.; TABAK, L. A.; MELVIN, J. E. Analysis of isoproterenol-induced changes in parotid gland gene expression. Physiol. Genomics, v. 8, p. 107-114, 2002.

TOOZE, S. A.; TOOZE, J.; WARREN, G. Site of addition of N-acetyl-galactosamine to the El glycoprotein of mouse hepatits virus. J. Cell Biol., v. 106, p. 1475, 1988.

TURNER, R. J.; SUGIYA, H. Understanding salivary fluid and protein secretion. Oral Dis., v. 8, n. 1, p. 3-11, 2002.

VON BÜLTZINGSLÖWEN, I.; SOLLECITO, T. P.; FOX, P. C.; DANIELS, T.; JONSSON, R.; LOCKHART, P. B.; WRAY, D.; BRENNAN, M. T.; CARROZZO, M.; GANDERA, B.; FUJIBAYASHI, T.; NAVAZESH, M.; RHODUS, N. L.; SCHIODT, M. Salivary dysfunction associated with systemic diseases: systematic review and clinical management recommendations. Oral Surg. Oral Med. Oral Pathol. Oral Radiol. Endod., v. 103, p. 115, 2007.

VUGMAN, I.; HAND, A. R. Quantitative immunocytochemical study of secretory protein expression in parotid glands of rats chronically treated with isoproterenol. Microsc. Res. Tech., v. 31, p. 106-117, 1995. 
XIANG, B.; ZHANG, Y.; LI, Y. M.; ZHANG, K.; ZHANG, Y. Y.; WU, L. L.; YU, G. Y. Effects of phenylephrine on transplanted submandibular gland. J. Dent. Res., v. 85, p. 11061111, 2006.

XIANG, B.; ZHANG, Y.; LI, Y. M.; GAO, Y.; GAN, Y. H.; WU, L. L.; YU, G. Y. Phenylephrine protects autotransplanted rabbit submandibular gland from apoptosis. Biochem Biophys. Res. Commum., v. 377, n. 1, p. 210-214, 2008.

WARSHAWSKY, H.; HADDAD, A.; GONÇALVES, R. P.; VALERI, V.; DE LUCCA, F. L. Fine structure of the venom gland epithelium of the South American rattlesnake and radioautographic studies of protein formation by secretory cells. Am. J. Anat., v. 138, p. 79 120, 1973.

WATSON, E.; DOWD, F.; JACOBSON, K.; HORWITZ, H. Reserpinization: effects on parotid gland and function. J. Dent. Res., v. 63, p. 82-86, 1984.

WILBORN, W. H.; SHACLEFORD, J. M. Microanatomy of human salivary glands. In: MENAKER, L. et al. (Eds.). The biologic basis of dental caries. An Oral Biology Textbook. Hagerstown: Harper and Row, 1980. p. 3-62.

WILCOX, W. B.; PINKSTAFF, C. A. Histology and mucosubstance histochemistry of the major salivary glands in Galago senegalensis. In: The lesser bushbaby (Galago) as an animal model. Boca Raton, FL: CRC Press, 1982. p. 199.

WISEMAN, L. R.; FAUDS, D. Oral pilocarpine: a review of its pharmacological properties and clinical potetntial in xerostomia. Drugs, v. 49, p. 143-155, 1995.

WOON, P. Y.; JEYASEELAN, K.; THIYAGARAJAH, P. Adrenergic regulation of RNA synthesis in the rat parotid gland. Biochem. Pharmacol., v. 45, n. 7, p.1395-1401, 1993.

WRIGHT, L. L.; LUEBKE, J. I. Somatostatin-, vasoactive intestinal polypeptide and neuropeptide Y-like immunoreactivity in eye- and submandibular gland projecting sympathetic neurons. Brain Rev., v. 494, p. 267-275, 1989.

YAMANOUYE, N.; BRITTO, L. R. G.; CARNEIRO, S. M.; MARKUS, R. P. Control of venom production and secretion by sympathetic outflow in the snake Bothrops jararaca. $\mathbf{J}$. Exp. Biol., v. 200, p. 2547-2556, 1997.

YAMANOUYE, N.; CARNEIRO, S. M.; SCRIVANO, C. N.; MARKUS, R. P. Characterization of $\beta$-adrenoceptors, responsible for venom production, in the venom gland of the snake Bothrops jararaca. Life Sci., v. 67, p. 217-226, 2000.

ZABLITH, M. B. Vias de sinalização desencadeadas pela estimulação do adrenoceptor $\beta$ em células secretoras da glândula de veneno da serpente Bothrops jararaca. $2007.78 \mathrm{f}$. Tese (Mestrado em Ciências) - Instituto de Ciências Biomédicas, Universidade de São Paulo, São Paulo, 2007. 


\section{APÊEDICES}

APÊNDICE A - Table 1: Proteins identified from highest density specific spots of the 2-DE of submandibular gland of the mouse in control group by nESILTQ/Orbitrap.

APÊNDICE B- Table 2: Proteins identified from highest density specific spots of the 2-DE of submandibular gland of the mouse in reserpine-treated groupby nESILTQ/Orbitrap.

APÊNDICE C- Table 3: Proteins identified from highest density specific spots of the 2-DE of submandibular gland of the mouse in reserpine plus adrenoceptor agonists-treated groupby nESI-LTQ/Orbitrap.

APÊNDICE D- Table 4: Proteins identified from highest density specific spots that had their densities increased after chronic treatment with reserpineof the 2-DE of submandibular gland of the mouse present in all the 3 groups by nESILTQ/Orbitrap.

APÊNDICE E -Table 5: Proteins identified from highest density specific spots that had their densities reduced after chronic treatment with reserpineof the 2-DE of submandibular gland of the mouse present in all the 3 groups by nESILTQ/Orbitrap.

APÊNDICE F -Table 6: Proteins identified from highest density spots of the 2-DE of submandibular gland of the mouse in common control and the reserpine + phenylephrine + isoprenaline-treated group by nESI-LTQ/Orbitrap.

APÊNDICE G -Table 7: Proteins identified from highest density specific spots of the 2-DE of parotid gland of the mouse in control group by nESI-LTQ/Orbitrap. 
APÊNDICE H -Table 8: Proteins identified from highest density specific spots of the 2-DE of parotid gland of the mouse in reserpine-treated groupby nESILTQ/Orbitrap.

APÊNDICE I -Table 9: Proteins identified from highest density specific spots of the 2-DE of parotid gland of the mouse in reserpine plus adrenoceptor agonists-treated groupby nESI-LTQ/Orbitrap.

Todas as tabelas listadas anteriormente estão presentes no CD anexo a esta Dissertação. 